\title{
Preparation of the Core Structure of Aspidosperma and Strychnos Alkaloids from Aryl Azides by a Cascade Radical Cyclization
}

Benjamin Wyler, François Brucelle and Philippe Renaud*

Universität Bern, Departement für Chemie und Biochemie, Freiestrasse 3, CH-3012 Bern, Switzerland.

philippe.renaud@dcb.unibe.ch

\section{Supporting Information}

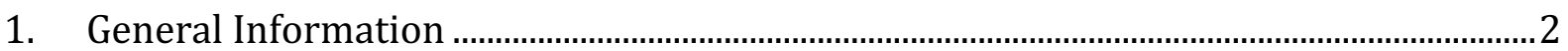

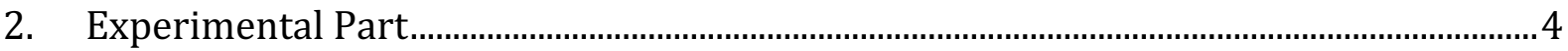

2.1. Preliminary Studies of the oxygenated analogue of the tetracyclic indoline........ 4

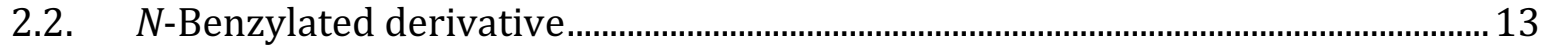

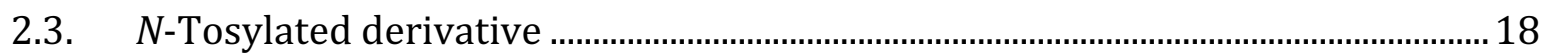

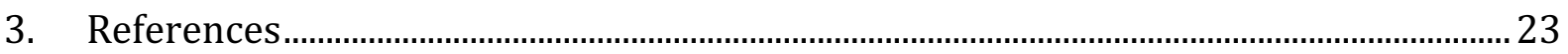

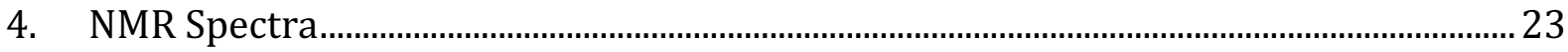




\section{General Information}

\section{Techniques}

All reactions requiring anhydrous conditions were performed in heat-gun, oven or flame dried glassware under an argon atmosphere. An ice bath was used to obtain a temperature of $0{ }^{\circ} \mathrm{C}$. A dry ice/acetone bath was used to obtain -78 and $-20^{\circ} \mathrm{C}$. Silica gel $60 \AA ̊(40-63 \mu \mathrm{m})$ from Silicycle was used for flash column chromatography. Thin layer chromatography (TLC) was performed on Silicycle silica gel $60 \mathrm{~F}_{254}$ plates, visualization under UV light $(254 \mathrm{~nm})$ and/or by dipping in a solution of $\left(\mathrm{NH}_{4}\right)_{2} \mathrm{MoO}_{4}(15.0 \mathrm{~g})$, $\mathrm{Ce}\left(\mathrm{SO}_{4}\right)_{2}(0.5 \mathrm{~g}), \mathrm{H}_{2} \mathrm{O}(90 \mathrm{~mL})$, conc. $\mathrm{H}_{2} \mathrm{SO}_{4}(10 \mathrm{~mL})$; or $\mathrm{KMnO}_{4}(3 \mathrm{~g}), \mathrm{K}_{2} \mathrm{CO}_{3}(20 \mathrm{~g})$ and $\mathrm{NaOH} 5 \%(3 \mathrm{~mL})$ in $\mathrm{H}_{2} \mathrm{O}(300 \mathrm{~mL})$ and subsequent heating. Anhydrous sodium sulfate was used as drying reagent.

\section{Materials}

Commercial reagents were used without further purification unless otherwise stated. Solvents for reactions (predistilled THF, predistilled $\mathrm{Et}_{2} \mathrm{O}, \mathrm{CH}_{3} \mathrm{CN}, \mathrm{CH}_{2} \mathrm{Cl}_{2}$, benzene, $n$ hexane, toluene) were filtered over columns of dried neutral aluminium oxide under a positive pressure of argon. Solvents for extractions and flash column chromatography were of technical grade and were distilled prior to use. Triethylborane solutions (1 M in hexane) were prepared from pure triethylborane (BASF or Aldrich, $2.9 \mathrm{~mL}, 20 \mathrm{mmol}$, in $17.1 \mathrm{~mL}$ of hexane). The solutions were stored at $\mathrm{rt}$ under an argon atmosphere in round bottom flasks closed with two septa and were generally used within two months.

\section{Instrumentations}

${ }^{1} \mathrm{H}$ and ${ }^{13} \mathrm{C}$ NMR spectra were recorded on a Bruker AVANCE-300 spectrometer operating at $300 \mathrm{MHz}$ for ${ }^{1} \mathrm{H}$ and $75 \mathrm{MHz}$ for ${ }^{13} \mathrm{C}$ at $22{ }^{\circ} \mathrm{C}$ unless otherwise stated. Some ${ }^{1} \mathrm{H}$ and ${ }^{13} \mathrm{C}$ NMR spectra were recorded on a Bruker Avance II-400 spectrometer $\left({ }^{1} \mathrm{H}\right.$ : $\left.400 \mathrm{MHz} ;{ }^{13} \mathrm{C}: 100 \mathrm{MHz}\right)$. Chemical shifts $(\delta)$ are reported in parts per million (ppm) using the residual solvent $\left(\mathrm{CHCl}_{3}: \delta=7.26\right.$ for ${ }^{1} \mathrm{H}$ NMR spectra and $\mathrm{CDCl}_{3}: \delta=77.00$ for ${ }^{13} \mathrm{C}$ NMR spectra) or $\mathrm{Si}\left(\mathrm{CH}_{3}\right)_{4}\left(\delta=0.00\right.$ for ${ }^{1} \mathrm{H}$ NMR spectra) as an internal standard. Multiplicities are given as $\mathrm{s}$ (singlet), $\mathrm{d}$ (doublet), $\mathrm{t}$ (triplet), $\mathrm{q}$ (quadruplet), $\mathrm{m}$ (multiplet), and br (broad). Coupling constants $(J)$ are reported in Hz. Infrared spectra were recorded on a Jasco FT-IR-460 Plus spectrometer equipped with a Specac MKII Golden Gate Single Reflection Diamond ATR System and are reported in wave numbers 
$\left(\mathrm{cm}^{-1}\right)$. Low resolution mass spectra were recorded on a Waters Micromass Autospec Q mass spectrometer in EI mode at $70 \mathrm{eV}$ or were taken from GC-MS analyses performed on a Finnigan Trace GC-MS (quadrupole mass analyzer using EI mode at $70 \mathrm{eV}$ ) fitted with a Macherey-Nagel Optima delta-3-0.25 $\mu \mathrm{m}$ capillary column (20 m, $0.25 \mathrm{~mm}$ ); gas carrier: He $1.4 \mathrm{~mL} / \mathrm{min}$; injector: $220^{\circ} \mathrm{C}$ split mode. HRMS analyses and accurate mass determinations were performed on a Thermo Scientific LTQ Orbitrap XL mass spectrometer using ESI mode at the University of Bern. Melting points were measured on a Büchi B-545 apparatus and are corrected.

Caution: Since organic azides are capable of exploding, it is strongly recommended to apply standard safety rules and to use a safety shield. 


\section{Experimental Part}

\subsection{Preliminary Studies of the oxygenated analogue of the tetracyclic indoline}

Commercially available cyclohex-2-enone $\mathbf{S 1}$ was iodinated in $88 \%$ yield. The resulting vinyl iodide $\mathbf{S} 2$ was then coupled with the 1-iodo-2-nitrobenzene in $65 \%$ yield using a palladium(0)-catalyzed Ullman cross-coupling reaction developed by Banwell. ${ }^{1}$ The resulting ketone $\mathbf{S} 3$ was reduced under Luche conditions, ${ }^{2}$ affording the allylic alcohol S4 in very high yield. The alcohol was protected and the nitro part was transformed to the corresponding aryl azide in a two step procedure ${ }^{3}$. After deprotection of the alcohol an acetyl chain was introduced and after a Finkelstein reaction the desired radical precursor $\mathbf{3}$ is formed. Alternatively the haloacetamide $\mathbf{5}$ was prepared as a diastereomeric mixture in $86 \%$ yield.
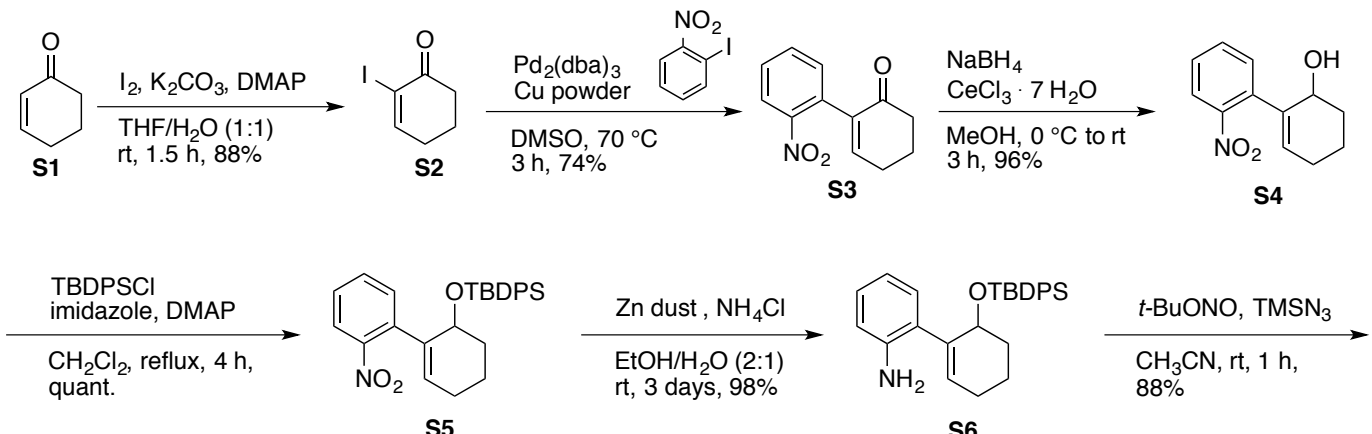

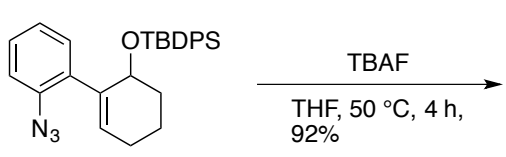

S7

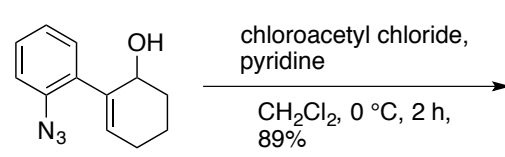<smiles>Nc1ccccc1C1=CCCCC1OC(=O)CCl</smiles>

s9

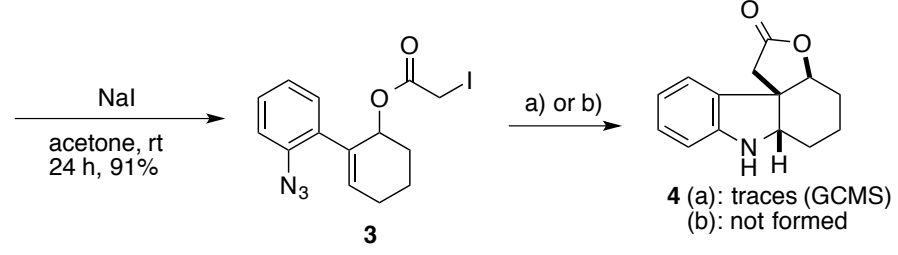

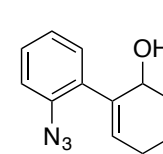

S8

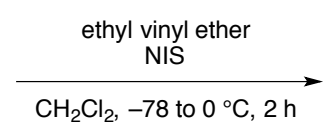

$<86 \%(52: 48 \mathrm{dr})$<smiles>CCOC(CI)OC1CCCC=C1c1ccccc1N</smiles>

5
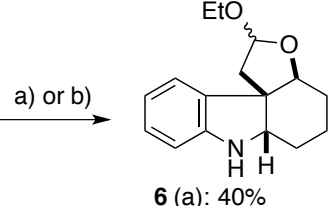

(b): not formed

a) $\mathrm{Et}_{3} \mathrm{~B}$ (2.5 eq), air, $\mathrm{C}_{6} \mathrm{H}_{6}$, reflux b) $\left(\mathrm{Me}_{3} \mathrm{Si}\right)_{3} \mathrm{SiH}$, AIBN, $\mathrm{C}_{6} \mathrm{H}_{6}$, reflux 


\section{2-Iodocyclohex-2-enone (S2)}

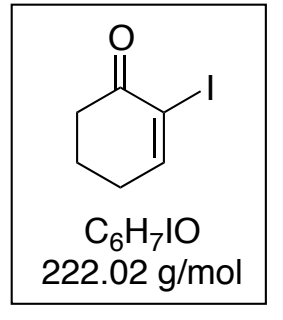

To a stirred solution of 2-cyclohexenone $\mathbf{S 1}(2.0 \mathrm{ml}, 20.5 \mathrm{mmol})$ in $\mathrm{THF} / \mathrm{H}_{2} \mathrm{O}(1: 1,100 \mathrm{~mL})$ was added at $\mathrm{rt} \mathrm{K}_{2} \mathrm{CO}_{3}$ (3.3 g, $\left.24 \mathrm{mmol}\right)$, iodine (10.15 g, $40 \mathrm{mmol}$ ) and DMAP (490 $\mathrm{mg}, 4 \mathrm{mmol}$ ) successively. The reaction mixture was stirred for $1.5 \mathrm{~h}$ at $\mathrm{rt}$ until completion. The solution was then diluted with EtOAc (200 mL), washed with $\mathrm{Na}_{2} \mathrm{~S}_{2} \mathrm{O}_{3}$ sat. aq. (1 x $400 \mathrm{~mL})$ and followed by $0.1 \mathrm{M} \mathrm{HCl}(1 \times 400 \mathrm{~mL})$. The organic layer was washed with brine, dried over $\mathrm{Na}_{2} \mathrm{SO}_{4}$, filtered and concentrated under reduced pressure. The crude was purified by flash column chromatography (pentane/Et $20,4: 1$ ) to give the desired product S2 (3.9 g, 88\%). Yellow solid. Physical and spectral data were in accordance with literature data. ${ }^{4}$ m.p.: $47-50{ }^{\circ} \mathrm{C} .{ }^{1} \mathbf{H}$ NMR (300 $\left.\mathbf{~ M H z}, \mathbf{C D C l}_{3}\right) \delta 7.75(\mathrm{t}$, $J=4.4 \mathrm{~Hz}, 1 \mathrm{H}), 2.66-2.62(\mathrm{~m}, 2 \mathrm{H}), 2.45-2.40(\mathrm{~m}, 2 \mathrm{H}), 2.11-2.04(\mathrm{~m}, 2 \mathrm{H}) .{ }^{13} \mathbf{C}$ NMR (75 MHz, $\mathbf{C D C l}_{3}$ ) $\delta$ 192.01, 159.34, 103.76, 37.16, 29.85, 22.76. MS (EI, 70 eV) $\mathbf{~ m / z ~ ( \% ) : ~} 222$ $\left(\mathrm{M}^{+}, 100\right), 193$ (77), 180 (9), 166 (15), 126 (11), 95 (14), 67 (22), 55 (19), 39 (71).

\section{2-(2-Nitrophenyl)-2-cyclohexen-1-one (S3)}

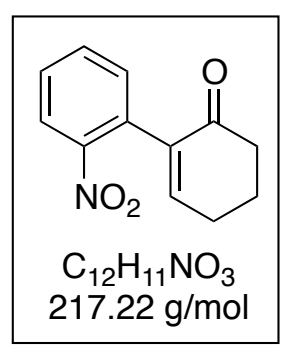

To a solution of 2-iodocyclohex-2-enone $\mathbf{S 2}$ (1.15 g, $5.2 \mathrm{mmol}$ ) and 1iodo-2-nitrobenzene (2.6 g, $10.4 \mathrm{mmol})$ in dry DMSO (13 $\mathrm{mL})$ at rt under argon was added $\mathrm{Pd}_{2}(\mathrm{dba})_{3} \cdot$ chloroform complex $(270 \mathrm{mg}, 0.26$ mmol) followed by $\mathrm{Cu}$ powder $(1.7 \mathrm{~g}, 26.5 \mathrm{mmol})$. The mixture was stirred at $70{ }^{\circ} \mathrm{C}$ for $3 \mathrm{~h}$. The reaction mixture was then cooled down to rt and $\mathrm{Et}_{2} \mathrm{O}(150 \mathrm{~mL})$ was added. The mixture was filtered through a pad of Celite (rinsed with Et20). The filtrate was washed with water $(1 \times 50 \mathrm{~mL})$, then brine $(1 \times 50$ $\mathrm{mL}$ ), dried over $\mathrm{Na}_{2} \mathrm{SO}_{4}$, filtered, and concentrated under reduced pressure. Purification by flash column chromatography (cyclohexane/AcOEt, 7:1 then 5:1) gave the desired product S3 (845 mg, 74\%).

Yellow solid. Physical and spectral data were in accordance with literature data. ${ }^{4} \mathbf{1}$ NMR (300 MHz, $\mathbf{C D C l}_{3}$ ) $\delta 8.02(\mathrm{dd}, J=8.1,1.2 \mathrm{~Hz}, 1 \mathrm{H}), 7.60(\mathrm{td}, J=7.5,1.3 \mathrm{~Hz}, 1 \mathrm{H}), 7.52$ $-7.42(\mathrm{~m}, 1 \mathrm{H}), 7.29-7.20(\mathrm{~m}, 1 \mathrm{H}), 7.00(\mathrm{t}, J=4.2 \mathrm{~Hz}, 1 \mathrm{H}), 2.64-2.53(\mathrm{~m}, 4 \mathrm{H}), 2.15(\mathrm{dt}, J$ $=12.3,6.2 \mathrm{~Hz}, 2 \mathrm{H}) .{ }^{13} \mathbf{C}$ NMR (75 MHz, $\left.\mathbf{C D C l}_{3}\right) \delta 196.44,148.65,146.46,139.50,133.25$, 132.17, 131.67, 128.74, 124.22, 38.31, 26.29, 22.59. (contaminated with homo-coupled product) 


\section{2'-Nitro-2,3,4,5-tetrahydro-[1,1'-biphenyl]-2-ol (S4)}

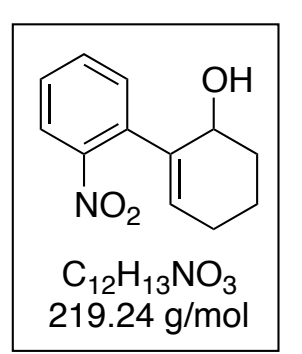

To a solution of S3 (1.99 g, $9.16 \mathrm{mmol})$ in $\mathrm{MeOH}$ at $0{ }^{\circ} \mathrm{C}$ under argon was added $\mathrm{CeCl}_{3} \cdot 7 \mathrm{H}_{2} \mathrm{O}(4.44 \mathrm{~g}, 11.91 \mathrm{mmol})$ in one portion. After 10 minutes, $\mathrm{NaBH}_{4}(450 \mathrm{mg}, 11.91 \mathrm{mmol}$ ) was added by portions $(3 \times$ $150 \mathrm{mg}$ ) in order to keep the temperature of the reaction mixture between 0 and $5{ }^{\circ} \mathrm{C}$. The mixture was then stirred at $0{ }^{\circ} \mathrm{C}$ for $1.5 \mathrm{~h}$ and

then at rt for 1.5 h. Sat. aq. $\mathrm{NH}_{4} \mathrm{Cl}(70 \mathrm{~mL})$ was added to the mixture and the methanol was removed under reduced pressure. The residue was extracted with $\mathrm{Et}_{2} \mathrm{O}(3 \times 40 \mathrm{~mL})$. The combined organic layers were washed with brine $(1 \times 40 \mathrm{~mL})$, dried over $\mathrm{Na}_{2} \mathrm{SO}_{4}$, filtered, and concentrated under reduced pressure. Purification by flash column chromatography (cyclohexane/AcOEt 5:1) gave S4 (1.88 g, $8.57 \mathrm{mmol}, 94 \%$ ).

Yellow solid. m.p.: $74-77^{\circ} \mathrm{C} .{ }^{1} \mathbf{H}$ NMR (300 $\left.\mathbf{M H z} \mathbf{C D C l}_{3}\right) \delta 7.84(\mathrm{dd}, J=8.1,1.3 \mathrm{~Hz}, 1 \mathrm{H})$, $7.56(\mathrm{td}, J=7.5,1.3 \mathrm{~Hz}, 1 \mathrm{H}), 7.45-7.35(\mathrm{~m}, 2 \mathrm{H}), 5.71(\mathrm{t}, J=3.8 \mathrm{~Hz}, 1 \mathrm{H}), 4.46-4.38(\mathrm{~m}$, 1H), 2.25-1.62 (m, 7H). ${ }^{13} \mathbf{C}$ NMR (75 MHz, $\left.\mathbf{C D C l}_{3}\right) \delta 149.42,137.65,136.82,132.46$, 131.43, 130.22, 127.89, 123.98, 67.59, 32.07, 25.60, 17.72. IR (neat): 3560, 3393 (br), 2935, 2863, 2832, 1661, 1606, 1570, 1518, 1342, 1056, 971, 915, 855, 782, 746. MS (EI, 70 eV) m/z (\%): 219 (M+, 1), 185 (22), 169 (47), 168 (84), 167 (100), 166 (23), 156 (16), 146 (32), 129 (28), 120 (29), 115 (36), 104 (16), 92 (21), 77 (32), 55 (20), 51 (23). HRMS (ESI) calcd for $\mathrm{C}_{12} \mathrm{H}_{13} \mathrm{NO}_{3} \mathrm{Na}$ : 242.0788, found: 242.0782 .

\section{tert-Butyl((2'-nitro-2,3,4,5-tetrahydro-[1,1'-biphenyl]-2-yl)oxy)diphenylsilane} (S5)

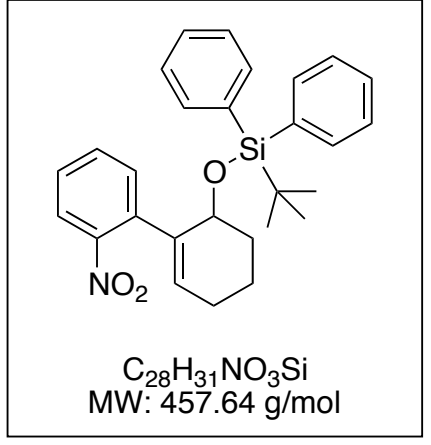

To a solution of S4 (2.14 g, $9.77 \mathrm{mmol})$, imidazole (1.33 g, $19.54 \mathrm{mmol}$ ), and DMAP (358 $\mathrm{mg}, 2.93 \mathrm{mmol}$ ) in dry $\mathrm{CH}_{2} \mathrm{Cl}_{2}$ $(10 \mathrm{~mL})$ at $0{ }^{\circ} \mathrm{C}$ under argon was added TBDPSCl $(5.08 \mathrm{~mL}$, $19.54 \mathrm{mmol}$ ) dropwise. The reaction mixture was refluxed for $4 \mathrm{~h}$. The mixture was cooled down to $\mathrm{rt}$ and water $(10 \mathrm{~mL})$ was added. The two layers were separated and the aqueous layer was extracted with $\mathrm{CH}_{2} \mathrm{Cl}_{2}(3 \times 5 \mathrm{~mL})$. The combined organic layers were washed with brine $(1 \times 5 \mathrm{~mL})$, dried over $\mathrm{Na}_{2} \mathrm{SO}_{4}$, filtered, and concentrated under reduced pressure. Purification by flash column chromatography (cyclohexane/AcOEt 99:1) gave $\mathbf{S 5}$ (4.46 g, $9.75 \mathrm{mmol}$, quantitative). 
Yellow solid. M.p.: $84-89^{\circ} \mathrm{C} .{ }^{1} \mathbf{H}$ NMR (300 $\left.\mathbf{M H z} \mathbf{C D C l}_{3}\right) \delta 7.86(\mathrm{dd}, J=8.0,1.2 \mathrm{~Hz}, 1 \mathrm{H})$, 7.55-7.26 (m, 11H), 7.24-7.17 (m, 2H), $5.67(\mathrm{t}, J=3.8 \mathrm{~Hz}, 1 \mathrm{H}), 4.50(\mathrm{t}, J=4.6 \mathrm{~Hz}, 1 \mathrm{H})$, 2.27-1.99 (m, 2H), 1.93-1.78 (m, 1H), 1.76-1.45 (m, 3H), 0.83 (s, 9H). ${ }^{13}$ C NMR (75 MHz, $\mathbf{C D C l}_{3}$ ) $\delta 148.18,139.39,137.79,135.82$ (2C), 135.67 (2C), 134.52, 133.57, 133.43, 132.38, 129.41, 129.36, 129.19, 127.58, 127.38 (2C), 127.36 (2C), 124.14, 68.75, 31.85, 26.79 (3C), 25.64, 19.17, 17.84. IR (neat): 3065, 2930, 2856, 1607, 1570, 1521, 1471, 1427, 1342, 1161, 1104, 1082, 1062, 1005, 997, 926, 898, 821, 737, 699. MS (EI, 70 eV) m/z (\%): 402 (3), 401 (10), 400 (30), 355 (2), 304 (3), 286 (2), 244 (3), 201 (6), 200 (19), 199 (100), 197 (11), 184 (6), 181 (9). HRMS (ESI) calcd for $\mathrm{C}_{28} \mathrm{H}_{31} \mathrm{NO}_{3} \mathrm{SiNa}$ : 480.1965, found: 480.1952 .

\section{2'-((tert-Butyldiphenylsilyl)oxy)-2',3',4',5'-tetrahydro-[1,1'-biphenyl]-2-amine}

(S6)

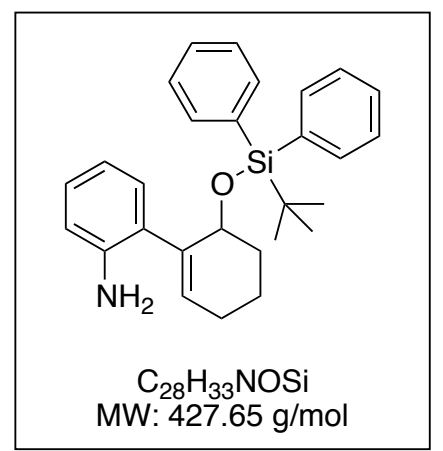

To a suspension of $\mathbf{S 5}(1.55 \mathrm{~g}, 3.38 \mathrm{mmol})$ in EtOH $(21 \mathrm{~mL})$ at rt was added a solution of $\mathrm{NH}_{4} \mathrm{Cl}$ (906 mg, $16.93 \mathrm{mmol}$ ) in water $(11 \mathrm{~mL})$ followed by $\mathrm{Zn}$ dust (3.32 g, $50.80 \mathrm{mmol})$. The reaction mixture was stirred at $\mathrm{rt}$ for 3 days. The mixture was then diluted with $\mathrm{CH}_{2} \mathrm{Cl}_{2}(20 \mathrm{~mL})$ and water $(5 \mathrm{~mL})$ and then filtered through a plug of cotton (rinsed with $\mathrm{CH}_{2} \mathrm{Cl}_{2}$ ). The filtrate was diluted with water $(10 \mathrm{~mL})$ and extracted with $\mathrm{CH}_{2} \mathrm{Cl}_{2}(3 \times 15 \mathrm{~mL})$. The combined organic layers were dried over $\mathrm{Na}_{2} \mathrm{SO}_{4}$, filtered, and concentrated under reduced pressure. Purification by flash column chromatography (cyclohexane/AcOEt 98:2) gave S6 (1.42 g, $3.32 \mathrm{mmol}, 98 \%$ ).

Colorless oil. ${ }^{1} \mathbf{H}$ NMR (300 MHz, $\mathbf{C D C l}_{3}$ ) $\delta 7.62(\mathrm{dd}, J=7.9,1.5 \mathrm{~Hz}, 2 \mathrm{H}), 7.44-7.24(\mathrm{~m}$, $6 \mathrm{H}), 7.22-7.14(\mathrm{~m}, 2 \mathrm{H}), 7.08(\mathrm{td}, J=7.8,1.6 \mathrm{~Hz}, 1 \mathrm{H}), 6.87(\mathrm{dd}, J=7.7,1.6 \mathrm{~Hz}, 1 \mathrm{H}), 6.74-$ $6.67(\mathrm{~m}, 2 \mathrm{H}), 5.82(\mathrm{t}, J=3.7 \mathrm{~Hz}, 1 \mathrm{H}), 4.45(\mathrm{t}, J=4.2 \mathrm{~Hz}, 1 \mathrm{H}), 3.71(\mathrm{br} \mathrm{s}, 2 \mathrm{H}), 2.28-2.15(\mathrm{~m}$, 1H), 2.07-1.92 (m, 1H), 1.91-1.75 (m, 1H), 1.68-1.57 (m, 1H), 1.53-1.37 (m, 2H), 0.87 (s, 9H). ${ }^{13}$ C NMR (75 MHz, $\mathbf{C D C l}_{3}$ ) $\delta$ 144.70, 138.43, 135.97 (2C), 135.93 (2C), 135.08, 133.57, 130.63, 129.76, 129.40, 129.24, 128.93, 127.75, 127.40 (2C), 127.29 (2C), 118.24, 115.43, 69.44, 32.13, 26.83 (3C), 25.72, 19.09, 17.87. IR (neat): 3451 (br), 3362 (br), 2930, 2856, 1611, 1490, 1471, 1451, 1426, 1361, 1291, 1159, 1104, 1061, 1011, 996, 919, 896, 821, 801, 737, 699. MS (EI, 70 eV) m/z (\%): $427\left(\mathrm{M}^{+}, 1\right), 372$ (5), 371 
(16), 370 (54), 292 (11), 274 (6), 226 (4), 201 (6), 200 (20), 199 (100), 197 (5), 181 (7).

HRMS (ESI) calcd for $\mathrm{C}_{28} \mathrm{H}_{34} \mathrm{NOSi}: 428.2404$, found: 428.2397.

\section{((2'-Azido-2,3,4,5-tetrahydro-[1,1'-biphenyl]-2-yl)oxy)(tert-butyl)diphenylsilane} (S7)

Cautions: $\mathrm{TMSN}_{3}$ is volatile, latex-permeable and absorbed by the skin. $\mathrm{TMSN}_{3}$ is known to be hydrolytically unstable, resulting in the release of hydrazoic acid, an unstable and very toxic compound. See also General Information.

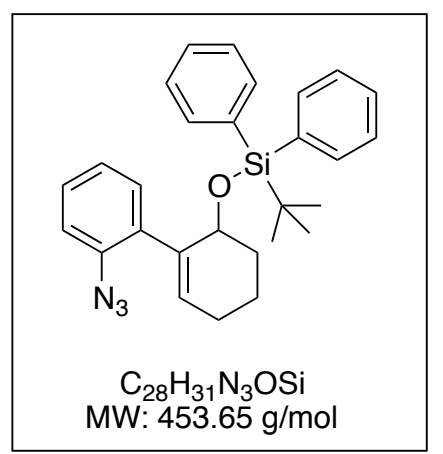

To a solution of $\mathbf{S 6}(1.41 \mathrm{~g}, 3.30 \mathrm{mmol})$ in dry $\mathrm{CH}_{3} \mathrm{CN}(8 \mathrm{~mL})$ at $0{ }^{\circ} \mathrm{C}$ under argon was added $t$-BuONO (90\% purity, $0.653 \mathrm{~mL}$, $4.94 \mathrm{mmol})$ dropwise followed by $\mathrm{TMSN}_{3}(0.52 \mathrm{~mL}, 3.96$ mmol) slowly. The reaction mixture was stirred at $\mathrm{rt}$ for $1 \mathrm{~h}$. The mixture was concentrated under reduced pressure. Purification by flash column chromatography (pentane then pentane/Et ${ }_{2} \mathrm{O} 10: 1$ ) gave $\mathbf{S 7}$ (1.33 g, $\left.2.93 \mathrm{mmol}, 88 \%\right)$.

Yellow oil. ${ }^{1} \mathbf{H}$ NMR (300 MHz, $\mathbf{C D C l}_{3}$ ) $\delta$ 7.58-7.53 (m, 2H), 7.43-7.19 (m, 9H), 7.12 (dd, J $=7.5,1.6 \mathrm{~Hz}, 1 \mathrm{H}), 7.02(\mathrm{t}, J=7.0 \mathrm{~Hz}, 1 \mathrm{H}), 6.95(\mathrm{~d}, J=8.0 \mathrm{~Hz}, 1 \mathrm{H}), 5.70(\mathrm{t}, J=3.8 \mathrm{~Hz}, 1 \mathrm{H})$, $4.66(\mathrm{t}, J=4.3 \mathrm{~Hz}, 1 \mathrm{H}), 2.28-2.15(\mathrm{~m}, 1 \mathrm{H}), 2.13-1.98(\mathrm{~m}, 1 \mathrm{H}), 1.95-1.82(\mathrm{~m}, 1 \mathrm{H}), 1.80-$ $1.69(\mathrm{~m}, 1 \mathrm{H}), 1.65-1.50(\mathrm{~m}, 2 \mathrm{H}), 0.82(\mathrm{~s}, 9 \mathrm{H}) .{ }^{13} \mathrm{C}$ NMR (75 $\left.\mathbf{M H z}, \mathbf{C D C l}_{3}\right) \delta$ 139.60, 137.26, 135.94 (2C), 135.89 (2C), 134.91, 134.56, 133.73, 131.87, 130.37, 129.30, 129.26, 127.99, 127.27 (2C), 127.21 (2C), 124.43, 118.17, 68.21, 31.99, 26.78 (3C), 25.58, 19.12, 17.88. IR (neat): 3070, 2930, 2856, 2121, 2089, 1575, 1484, 1472, 1441, 1426, 1288, 1104, 1062, 1013, 997, 922, 897, 859, 820, 737, 699. MS (EI, 70 eV) $\mathbf{m} / \mathbf{z}$

(\%): the product completely decomposed during the analysis, no detection possible. HRMS (ESI) calcd for $\mathrm{C}_{28} \mathrm{H}_{31} \mathrm{~N}_{3} \mathrm{OSiNa:} 476.2129$, found: 476.2121 .

\section{2'-Azido-2,3,4,5-tetrahydro-[1,1'-biphenyl]-2-ol (S8)}

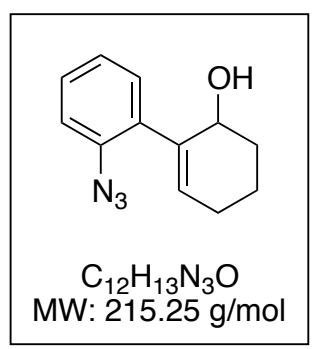

Caution: See General Information.

To a solution of $\mathbf{S} 7(1.15 \mathrm{~g}, 2.54 \mathrm{mmol})$ in dry THF $(48 \mathrm{~mL})$ at $0{ }^{\circ} \mathrm{C}$ under argon was added a $1 \mathrm{M}$ solution of TBAF in THF $(12.69 \mathrm{~mL}$, $12.69 \mathrm{mmol}$ ). The mixture was stirred at $50{ }^{\circ} \mathrm{C}$ for $4 \mathrm{~h}$. The mixture was then cooled down to $\mathrm{rt}$ and water $(150 \mathrm{~mL})$ and $\mathrm{CH}_{2} \mathrm{Cl}_{2}(150 \mathrm{~mL})$ were added. The two layers were separated and the aqueous layer 
was extracted with $\mathrm{CH}_{2} \mathrm{Cl}_{2}(3 \times 150 \mathrm{~mL})$. The combined organic layers were dried over $\mathrm{Na}_{2} \mathrm{SO}_{4}$, filtered, and concentrated under reduced pressure. Purification by flash column chromatography (pentane/Et $2 \mathrm{O}$ 15:1 then 5:1) gave $\mathbf{S 8}$ (502 mg, $2.33 \mathrm{mmol}, 92 \%$ ).

Yellow oil. ${ }^{1} \mathbf{H}$ NMR (300 MHz, $\mathbf{C D C l}_{3}$ ) $\delta$ 7.36-7.28 (m, 1H), 7.22-7.08 (m, 3H), 5.80 (t, $J=$ $3.8 \mathrm{~Hz}, 1 \mathrm{H}), 4.59(\mathrm{t}, J=4.4 \mathrm{~Hz}, 1 \mathrm{H}), 2.32-2.07(\mathrm{~m}, 2 \mathrm{H}), 2.01-1.62(\mathrm{~m}, 5 \mathrm{H}) .{ }^{13} \mathrm{C}$ NMR (75 MHz, $\left.\mathbf{C D C l}_{3}\right) \delta 138.74,137.22,133.77,131.28,131.19,128.50,124.93,118.30,67.02$, 31.51, 25.77, 17.87. IR (neat): 3358 (br), 2933, 2858, 2832, 2118, 2085, 1573, 1493, 1440, 1285, 1159, 1147, 1057, 970, 914, 748. MS (EI, 70 eV) m/z (\%): $215\left(\mathrm{M}^{+}, 1\right), 187$ $\left(\mathrm{M}^{+}-\mathrm{N}_{2}, 12\right), 170$ (28), 169 (45), 168 (71), 167 (39), 143 (17), 131 (26), 130 (100), 115 (22), 103 (15), 89 (12), 77 (20), 63 (11), 51 (15), 39 (16). HRMS (ESI) calcd for $\mathrm{C}_{12} \mathrm{H}_{13} \mathrm{~N}_{3} \mathrm{ONa}$ : 238.0951, found: 238.0949 .

\section{2'-Azido-2,3,4,5-tetrahydro-[1,1'-biphenyl]-2-yl 2-chloroacetate (S9)}

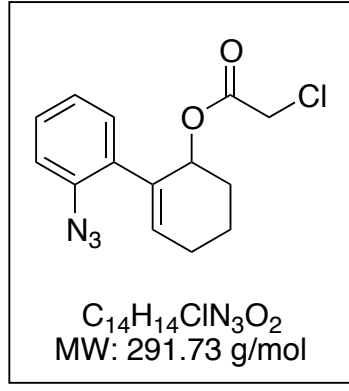

Caution: See General Information.

To a solution of $\mathbf{S 8}(200 \mathrm{mg}, 0.93 \mathrm{mmol})$ in dry $\mathrm{CH}_{2} \mathrm{Cl}_{2}(7.5 \mathrm{~mL})$ at rt under argon was added pyridine $(0.150 \mathrm{~mL}, 1.86 \mathrm{mmol})$. The reaction mixture was cooled down to $0{ }^{\circ} \mathrm{C}$ and chloroacetyl chloride $(0.148 \mathrm{~mL}, 1.86 \mathrm{mmol})$ was added dropwise. The mixture was stirred at $0{ }^{\circ} \mathrm{C}$ for $2 \mathrm{~h}$. The mixture was then diluted with $\mathrm{CH}_{2} \mathrm{Cl}_{2}(12 \mathrm{~mL})$ and washed with water $(3 \times 12 \mathrm{~mL})$. The organic layer was dried over $\mathrm{Na}_{2} \mathrm{SO}_{4}$, filtered, and concentrated under reduced pressure. Purification by flash column chromatography (pentane/Et 20 99:1 then 98:2) gave $\mathbf{S 9}$ (239 $\mathrm{mg}, 0.82 \mathrm{mmol}, 89 \%$ ). Yellowish oil. ${ }^{1} \mathbf{H}$ NMR (300 MHz, $\mathbf{C D C l}_{3}$ ) $\delta$ 7.33-7.27 (m, 1H), 7.15-7.03 (m, 3H), 5.97 (t, $J=3.9 \mathrm{~Hz}, 1 \mathrm{H}), 5.92(\mathrm{t}, J=4.4 \mathrm{~Hz}, 1 \mathrm{H}), 3.85(\mathrm{q}, J=14.7 \mathrm{~Hz}, 2 \mathrm{H}), 2.37-2.12(\mathrm{~m}, 2 \mathrm{H}), 2.07-$ $1.91(\mathrm{~m}, 2 \mathrm{H}), 1.85-1.70(\mathrm{~m}, 2 \mathrm{H}) .{ }^{13} \mathbf{C}$ NMR (75 MHz, $\left.\mathbf{C D C l}_{3}\right) \delta 166.69,137.54,134.30$, 134.05, 132.52, 130.90, 128.69, 124.62, 118.38, 71.37, 40.97, 28.43, 25.39, 17.71. IR (neat): 2942, 2863, 2832, 2121, 2091, 1752, 1729, 1574, 1484, 1441, 1410, 1278, 1180, 1156, 1091, 1052, 1006, 965, 916, 750. MS (EI, 70 eV) m/z (\%): $291\left(\mathrm{M}^{+}\right.$, 1), $170(6)$, 169 (61), 168 (100), 167 (43), 166 (10), 139 (5), 115 (7), 83 (18), 50 (6). HRMS (ESI) calcd for $\mathrm{C}_{14} \mathrm{H}_{14} \mathrm{ClN}_{3} \mathrm{O}_{2} \mathrm{Na}$ : 314.0667, found: 314.0665 . 


\section{2'-Azido-2,3,4,5-tetrahydro-[1,1'-biphenyl]-2-yl 2-iodoacetate (3)}

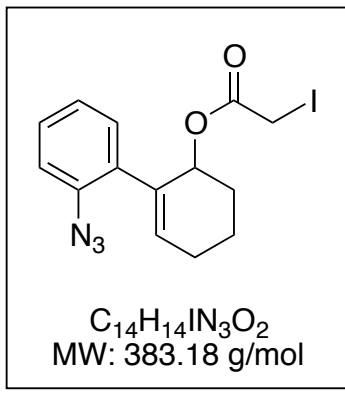

Caution: See General Information.

To a solution of $\mathbf{S 9}(100 \mathrm{mg}, 0.34 \mathrm{mmol})$ in acetone $(2 \mathrm{~mL})$ at $\mathrm{rt}$ under argon was added $\mathrm{NaI}$ (67 $\mathrm{mg}, 0.45 \mathrm{mmol}$ ). The mixture was stirred at rt for $24 \mathrm{~h}$ (caution: flask wrapped in aluminum foil to protect the reaction from light). The solvent was then removed under reduced pressure (caution: flask wrapped in aluminum foil) and the residue was dissolved in a mixture of water $(5 \mathrm{~mL})$ and $\mathrm{CH}_{2} \mathrm{Cl}_{2}(5 \mathrm{~mL})$. The two layers were separated and the aqueous layer was extracted with $\mathrm{CH}_{2} \mathrm{Cl}_{2}(3 \times 3 \mathrm{~mL})$. The combined organic layers were successively washed with sat. aq. $\mathrm{Na}_{2} \mathrm{~S}_{2} \mathrm{O}_{3}(2 \times 3 \mathrm{~mL})$ and brine $(1 \times 3 \mathrm{~mL})$, dried over $\mathrm{Na}_{2} \mathrm{SO}_{4}$, filtered, and concentrated under reduced pressure (caution: flask wrapped in aluminum foil). Purification by flash column chromatography (pentane/Et ${ }_{2} \mathrm{O}$ 95:5) gave 3 (120 mg, $\left.0.31 \mathrm{mmol}, 91 \%\right)$.

Yellowish oil. ${ }^{1} \mathbf{H}$ NMR (300 $\left.\mathbf{~ M H z , ~} \mathbf{C D C l}_{3}\right) \delta$ 7.32-7.26 (m, 1H), 7.18-7.04 (m, 3H), $5.97(\mathrm{t}$, $J=3.8 \mathrm{~Hz}, 1 \mathrm{H}), 5.87(\mathrm{t}, J=4.4 \mathrm{~Hz}, 1 \mathrm{H}), 3.50(\mathrm{~s}, 2 \mathrm{H}), 2.37-2.12(\mathrm{~m}, 2 \mathrm{H}), 2.05-1.68(\mathrm{~m}, 4 \mathrm{H})$. ${ }^{13}$ C NMR (75 MHz, $\left.\mathbf{C D C l}_{3}\right) \delta$ 168.23, 137.51, 134.45, 133.91, 132.67, 131.03, 128.59, 124.66, 118.42, 70.96, 28.16, 25.43, 17.80, -5.17. IR (neat): 3051, 2939, 2863, 2120, 2090, 1721, 1573, 1484, 1441, 1413, 1248, 1081, 1006, 967, 918, 749, 683. MS (EI, 70 eV) $\boldsymbol{m} / \mathbf{z}(\%): 170$ (8), 169 (57), 168 (100), 167 (49), 166 (11), 139 (8), 83 (23), 63 (5). HRMS (ESI) calcd for $\mathrm{C}_{14} \mathrm{H}_{14} \mathrm{IN}_{3} \mathrm{O}_{2} \mathrm{Na}$ : 406.0023, found: 406.0015 .

\section{2'-Azido-2-(1-ethoxy-2-iodoethoxy)-2,3,4,5-tetrahydro-1,1'-biphenyl (5)}

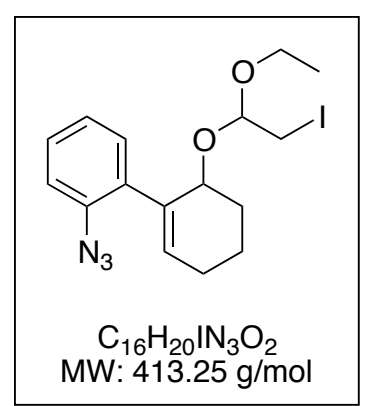

Caution: See General Information.

To a solution of $\mathbf{S 8}(100 \mathrm{mg}, 0.46 \mathrm{mmol})$ in dry $\mathrm{CH}_{2} \mathrm{Cl}_{2}(1 \mathrm{~mL})$ at rt under argon was added ethyl vinyl ether (67 $\mu \mathrm{L}, 0.70 \mathrm{mmol})$. The mixture was cooled down to $-78^{\circ} \mathrm{C}$ and NIS (157 $\mathrm{mg}, 0.70 \mathrm{mmol}$ ) was added portionwise. The mixture was stirred at $-78{ }^{\circ} \mathrm{C}$ for 5 minutes then allowed to slowly warm up to $0{ }^{\circ} \mathrm{C}$ over $2 \mathrm{~h}$

(caution: flask wrapped in aluminum foil to protect the reaction from light). The mixture was diluted with $\mathrm{CH}_{2} \mathrm{Cl}_{2}(2 \mathrm{~mL})$, then washed with water $(1 \times 2 \mathrm{~mL})$ and a $10 \%$ aqueous $\mathrm{Na}_{2} \mathrm{~S}_{2} \mathrm{O}_{3}$ solution $(1 \times 2 \mathrm{~mL})$, dried over $\mathrm{Na}_{2} \mathrm{SO}_{4}$, filtered, and concentrated under reduced pressure (caution: flask wrapped in aluminum foil). Purification by flash column chromatography (pentane/Et ${ }_{2} \mathrm{O}$ 98:2) gave $\mathbf{5}$ as a mixture of diastereomers 
contaminated with unidentified side products $(166 \mathrm{mg},<86 \%, 52: 48 \mathrm{dr}$ as determined by ${ }^{1} \mathrm{H}$ NMR). The diastereomers were inseparable.

Mixture of diastereomers: yellowish oil. ${ }^{\mathbf{1}} \mathbf{H}$ NMR (300 $\left.\mathbf{~ M H z}, \mathbf{C D C l}_{3}\right) \delta 7.34-7.05(\mathrm{~m}, 4 \mathrm{H}$ major $+4 \mathrm{H}$ minor), $5.85(\mathrm{t}, J=3.8 \mathrm{~Hz}, 1 \mathrm{H}$ major $), 5.81(\mathrm{t}, J=3.8 \mathrm{~Hz}, 1 \mathrm{H}$ minor $), 4.65(\mathrm{t}, J=$ $5.6 \mathrm{~Hz}, 1 \mathrm{H}$ major), $4.58(\mathrm{t}, J=3.2 \mathrm{~Hz}, 1 \mathrm{H}$ major), 4.52 (t, $J=4.1 \mathrm{~Hz}, 1 \mathrm{H}$ minor), 4.39 (dd, $J$ = 6.6, $4.2 \mathrm{~Hz}, 1 \mathrm{H}$ minor), 3.54-2.67 (m, $4 \mathrm{H}$ major $+4 \mathrm{H}$ minor), 2.32-1.61 (m, $6 \mathrm{H}$ major + 6H minor), 1.16 ( $\mathrm{t}, J=7.0 \mathrm{~Hz}, 3 \mathrm{H}$ minor), 0.82 ( $\mathrm{t}, J=7.0 \mathrm{~Hz}, 3 \mathrm{H}$ major). IR (neat): 2973, 2933, 2119, 2086, 1573, 1483, 1441, 1283, 1097, 1045, 1008, 920, 750. MS (EI, 70 eV) m/z (\%): 170 (14), 169 (63), 168 (100), 167 (56), 166 (12), 139 (8), 83 (22). HRMS (ESI) calcd for $\mathrm{C}_{16} \mathrm{H}_{20} \mathrm{IN}_{3} \mathrm{O}_{2} \mathrm{Na}: 436.0492$, found: 436.0486 .

Major diastereomer: ${ }^{13} \mathbf{C}$ NMR (75 $\mathbf{~ M H z , ~} \mathbf{C D C l}_{3}$ ) $\delta=137.33,136.36,134.43,132.54$, 131.66, 128.32, 124.63, 118.18, 102.54, 70.92, 61.56, 28.01, 25.55, 16.96, 14.80, 6.10.

Minor diastereomer: ${ }^{13} \mathbf{C}$ NMR (75 $\mathbf{M H z}, \mathbf{C D C l}_{3}$ ) $\delta=137.20,136.82,134.29,132.12$, $131.71,128.46,124.83,118.32,100.00,72.92$, 59.01, 29.84, 25.58, 17.65, 14.99, 5.61.

\section{2-Ethoxy-1,2,3a,4,5,6,6a,7-octahydrofuro[2,3-d]carbazole (6)}

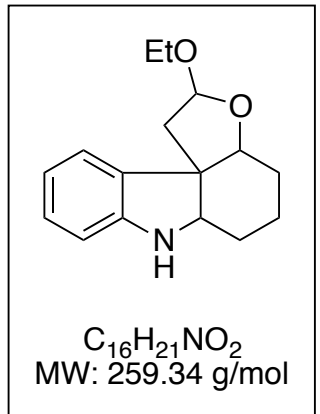

To an open to air solution of 5 (118 $\mathrm{mg}, 0.28 \mathrm{mmol}$, 52:48 $\mathrm{dr}$ as determined by $\left.{ }^{1} \mathrm{H} \mathrm{NMR}\right)$ in benzene $(0.8 \mathrm{~mL})$ at $\mathrm{rt}$, in a 2-necked 10 $\mathrm{mL}$ round bottom flask, was added a $1 \mathrm{M}$ solution of $\mathrm{Et}_{3} \mathrm{~B}$ in hexane (0.14 $\mathrm{mL}, 0.14 \mathrm{mmol}$ ) with a syringe (cautions: the needle should be immersed into the reaction mixture in order to avoid a direct contact of $E t_{3} B$ drops with air. Flask wrapped in aluminum foil to protect the reaction from light). The reaction mixture was stirred at $\mathrm{rt}$ for 30 minutes then $\mathrm{Et}_{3} \mathrm{~B}$ (0.14 $\mathrm{mL}, 0.14 \mathrm{mmol}$ ) was added. The reaction mixture was stirred at rt for 30 minutes then $\mathrm{Et}_{3} \mathrm{~B}(0.14 \mathrm{~mL}, 0.14 \mathrm{mmol})$ was added. After $1 \mathrm{~h}$ at $\mathrm{rt}$, the reaction mixture was refluxed and $\mathrm{Et}_{3} \mathrm{~B}(0.14 \mathrm{~mL}, 0.14 \mathrm{mmol})$ was added. The mixture was stirred at reflux for 30 minutes then $\mathrm{Et}_{3} \mathrm{~B}(0.14 \mathrm{~mL}, 0.14 \mathrm{mmol})$ was added. The reaction mixture was refluxed for $1.5 \mathrm{~h}$ then sat. aq. $\mathrm{NaHCO}_{3}(5 \mathrm{~mL})$ was added. The two layers were separated and the aqueous layer was extracted with $\mathrm{Et}_{2} \mathrm{O}(3 \times 3 \mathrm{~mL})$. The combined organic layers were washed with brine $(1 \times 3 \mathrm{~mL})$, dried over $\mathrm{Na}_{2} \mathrm{SO}_{4}$, filtered, and concentrated under reduced pressure at $35{ }^{\circ} \mathrm{C}$. Purification by flash column chromatography (cyclohexane/AcOEt 8:1) gave 6 as a mixture of diastereomers 
contaminated with unidentified side products $(29 \mathrm{mg},<40 \%, 55: 45 \mathrm{dr}$ as determined by ${ }^{1} \mathrm{H}$ NMR). The diastereomers were inseparable.

Mixture of diastereomers: yellow oil. Due to the low purity of the mixture after chromatography, only the ${ }^{1} \mathrm{H}$ NMR and GC-MS analyses have been performed. ${ }^{\mathbf{1}} \mathbf{H} \mathbf{N M R}$ $\left(300 \mathbf{M H z} \mathbf{C D C l}_{3}\right)$ (the observable signals that confirmed the structure of 6 have been listed) $\delta 7.16(\mathrm{~d}, J=6.9 \mathrm{~Hz}, 1 \mathrm{H}$ major), $7.09-6.64(\mathrm{~m}, 3 \mathrm{H}$ major $+4 \mathrm{H}$ minor $), 5.26(\mathrm{dd}, J=$ 6.0, $1.8 \mathrm{~Hz}, 1 \mathrm{H}$ major), 5.21 (dd, $J=5.8,4.5 \mathrm{~Hz}, 1 \mathrm{H}$ minor), 4.56 (t, J = 2.6 Hz, $1 \mathrm{H}$ minor), 4.30-4.25 (m, 1H major), 4.04 (dd, $J=8.3,5.3 \mathrm{~Hz}, 1 \mathrm{H}$ major), 3.90-3.77 (m, $1 \mathrm{H}$ major + 2H minor), 3.57-3.39 (m, 2H major $+2 \mathrm{H}$ minor), 2.72 (dd, $J=13.8,6.0 \mathrm{~Hz}, 1 \mathrm{H}$ minor).

Major diastereomer: MS (EI, 70 eV) m/z (\%): $259\left(\mathrm{M}^{+}, 62\right), 214$ (21), 188 (36), 170 (83), 159 (92), 130 (100), 118 (27), 77 (22).

Minor diastereomer: MS (EI, 70 eV) m/z (\%): $259\left(\mathrm{M}^{+}, 65\right), 214$ (25), 188 (54), 170 (81), 159 (96), 130 (100), 118 (27), 77 (24). 


\subsection{N-Benzylated derivative}

The synthesis of the amino azide $\mathbf{S 1 3}$ was finally achieved from the nitro alcohol S4 after conversion of its hydroxy functionality into an azido group and a Staudinger reaction/hydrolysis/reductive amination sequence. Indeed, via a Mitsunobu reaction involving diphenylphosphoryl azide (DPPA), S4 was readily converted into the azide S10 in 88\% yield..$^{5}$ From S10, the nitro amine $\mathbf{S 1 1}$ was successfully prepared using the optimized sequence mentioned above. Since the complete separation of $\mathbf{S 1 1}$ from small amounts of benzyl alcohol, resulting from the partial reduction of benzaldehyde by $\mathrm{NaBH}_{4}$, was not possible, the nitro amine was used as a crude product in the subsequent reduction step. The aniline $\mathbf{S 1 2}$ was then obtained in 61\% yield from S10. Finally, $\mathbf{S 1 2}$ was converted into the amino azide $\mathbf{S 1 3}$ in good yield with the $\mathrm{NaNO}_{2} / \mathrm{NaN}_{3} / \mathrm{HCl}$ system. After an acetylation with chloroacetylchloride and a Finkelstein reaction the desired radical precursor $\mathbf{1 a}$ is formed.
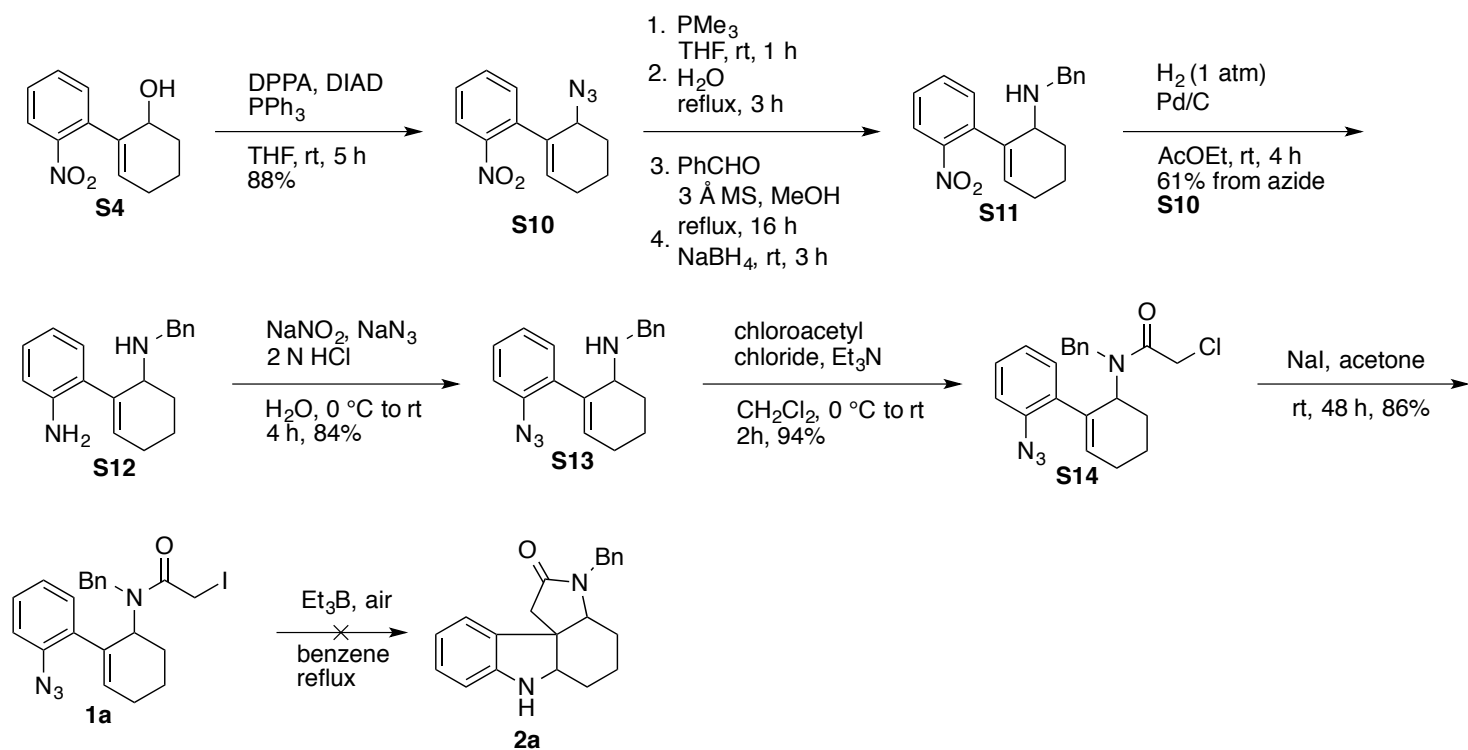

\section{2-Azido-2'-nitro-2,3,4,5-tetrahydro-1,1'-biphenyl (S10)}

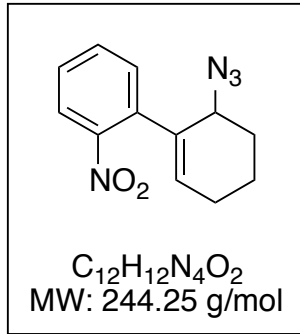

To a solution of S4 (2.02 g, $9.22 \mathrm{mmol})$ and $\mathrm{PPh}_{3}(3.14 \mathrm{~g}, 11.98$ mmol) in dry THF (41 mL) at $0{ }^{\circ} \mathrm{C}$ under argon was slowly added DIAD (2.32 mL, $11.98 \mathrm{mmol}$ ) followed by DPPA (2.59 mL, 11.98 mmol) dropwise. The reaction mixture was stirred at $\mathrm{rt}$ for $5 \mathrm{~h}$. The solvent was then removed under reduced pressure. Purification by 
flash column chromatography (cyclohexane/toluene 3:1) gave $\mathbf{S 1 0}$ (1.98 g, $8.11 \mathrm{mmol}$, $88 \%)$.

Yellowish oil. ${ }^{1} \mathbf{H}$ NMR (300 MHz, $\left.\mathbf{C D C l}_{3}\right) \delta 7.98(\mathrm{dd}, J=8.1,1.2 \mathrm{~Hz}, 1 \mathrm{H}), 7.60(\mathrm{td}, J=7.5$, $1.2 \mathrm{~Hz}, 1 \mathrm{H}$ ), 7.46 (td, $J=8.1,1.5 \mathrm{~Hz}, 1 \mathrm{H}$ ), 7.39 (dd, $J=7.5,1.5 \mathrm{~Hz}, 1 \mathrm{H}), 5.87$ (t, $J=3.8 \mathrm{~Hz}$, 1H), $4.14(\mathrm{t}, J=4.3 \mathrm{~Hz}, 1 \mathrm{H}), 2.34-1.99(\mathrm{~m}, 4 \mathrm{H}), 1.92-1.70(\mathrm{~m}, 2 \mathrm{H}) .{ }^{13} \mathbf{C}$ NMR (75 MHz, $\left.\mathrm{CDCl}_{3}\right) \delta 148.27,136.60,134.43,133.06,132.33,131.53,128.42,124.41,58.83,28.76$, 25.21, 17.62. IR (neat): 2939, 2867, 2090, 1607, 1570, 1520, 1438, 1341, 1297, 1243, 1159, 1091, 941, 913, 849, 785, 747. MS (EI, 70 eV) m/z (\%): 244 (M+, 0.1), 202 (77), 184 (36), 170 (35), 168 (46), 167 (31), 131 (25), 130 (73), 115 (100), 104 (80), 92 (69), 91 (56), 89 (53), 77 (96), 76 (54), 63 (41), 55 (52), 51 (44), 39 (34). HRMS (ESI) calcd for $\mathrm{C}_{12} \mathrm{H}_{12} \mathrm{~N}_{4} \mathrm{O}_{2} \mathrm{Na}$ : 267.0852, found: 267.0855.

\section{$N^{2}$-Benzyl-2,3,4,5-tetrahydro-[1,1'-biphenyl]-2,2'-diamine (S12)}

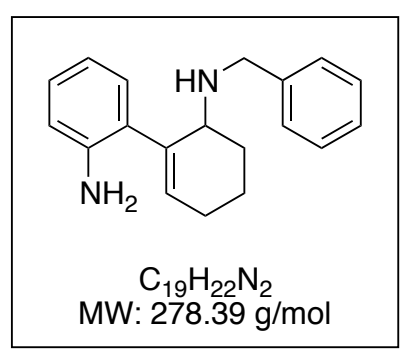

To a solution of $\mathbf{S 1 0}(1.17 \mathrm{~g}, 4.79 \mathrm{mmol})$ in dry THF (22 $\mathrm{mL})$ at rt under argon was slowly added a $1 \mathrm{M}$ solution of $\mathrm{PMe}_{3}$ in THF (19.16 $\mathrm{mL}, 19.16 \mathrm{mmol})$. The reaction mixture was stirred at $\mathrm{rt}$ for $1 \mathrm{~h}$ then water $(0.60 \mathrm{~mL}, 33.53 \mathrm{mmol})$ was added and the mixture was refluxed for $3 \mathrm{~h}$. The mixture was then cooled down to rt, concentrated under reduced pressure, and azeotropically dried with toluene $(3 \times 40 \mathrm{~mL})$. The residue was dissolved in $\mathrm{MeOH}(99 \mathrm{~mL})$ then activated $3 \AA$ molecular sieves (20 g) were added followed by freshly distilled benzaldehyde $(0.49 \mathrm{~mL}, 4.79$ mmol). The mixture was refluxed for $16 \mathrm{~h}$. The mixture was then cooled down to $0{ }^{\circ} \mathrm{C}$ and $\mathrm{NaBH}_{4}$ (200 mg, $5.27 \mathrm{mmol}$ ) was added portionwise. The reaction mixture was stirred at $\mathrm{rt}$ for $3 \mathrm{~h}$. The mixture was then filtered to remove the solids (rinsed with $\mathrm{MeOH})$ and the filtrate was concentrated under reduced pressure. The residue was dissolved in $\mathrm{CH}_{2} \mathrm{Cl}_{2}(30 \mathrm{~mL})$ and sat. aq. $\mathrm{NaHCO}_{3}(30 \mathrm{~mL})$. The two layers were separated and the aqueous layer was extracted with $\mathrm{CH}_{2} \mathrm{Cl}_{2}(3 \times 10 \mathrm{~mL})$. The combined organic layers were washed with brine $(1 \times 10 \mathrm{~mL})$, dried over $\mathrm{Na}_{2} \mathrm{SO}_{4}$, filtered, and concentrated under reduced pressure. The crude product S11 (1.53 g) obtained was dissolved in EtOAc (109 mL) at rt under argon and the solution was degassed with argon under a slight vacuum for 5 minutes to remove the oxygen. 5\% Pd/C (611 mg, 0.29 mmol) was added under argon and the mixture was degassed with argon for 1 minute. The mixture was stirred under an atmosphere (balloon) of $\mathrm{H}_{2}$ at $\mathrm{rt}$ for $4 \mathrm{~h}$. The mixture 
was then filtered through a pad of Celite (rinsed with EtOAc) and the filtrate was concentrated under reduced pressure. Purification by flash column chromatography $\left(\mathrm{CH}_{2} \mathrm{Cl}_{2}\right.$ then $\mathrm{CH}_{2} \mathrm{Cl}_{2} / \mathrm{NH}_{3}(7 \mathrm{~N}$ in $\mathrm{MeOH})$ 99.5:0.5 then 99:1) gave $\mathbf{S 1 2}$ (810 mg, 2.91 $\mathrm{mmol}, 61 \%$ from azide $\mathbf{S 1 0}$ ).

Yellow liquid. ${ }^{1} \mathbf{H}$ NMR (300 MHz, $\left.\mathbf{C D C l}_{3}\right) \delta 7.26-7.15(\mathrm{~m}, 3 \mathrm{H}), 7.11-7.03(\mathrm{~m}, 3 \mathrm{H}), 6.93$ (dd, $J=7.5,1.4 \mathrm{~Hz}, 1 \mathrm{H}), 6.74-6.65(\mathrm{~m}, 2 \mathrm{H}), 5.83(\mathrm{td}, J=3.8,0.9 \mathrm{~Hz}, 1 \mathrm{H}), 3.75$ (d, $J=13.3$ $\mathrm{Hz}, 1 \mathrm{H}), 3.59$ (d, $J=13.3 \mathrm{~Hz}, 1 \mathrm{H}), 3.46(\mathrm{t}, J=3.7 \mathrm{~Hz}, 1 \mathrm{H}), 3.14(\mathrm{br} \mathrm{s}, 2 \mathrm{H}), 2.31-2.01(\mathrm{~m}$, 2H), 1.93 - 1.56 (m, 5H). ${ }^{13} \mathbf{C}$ NMR (75 MHz, CDCl $\left._{3}\right) \delta$ 144.47, 140.51, 138.72, 129.81, $129.47,128.24$ (2C), 128.04, 127.98 (2C), 127.89, 126.68, 118.13, 115.47, 54.34, 51.46, 28.13, 25.77, 18.30. IR (neat): 3446 (br), 3357 (br), 3023, 2930, 1610, 1490, 1450, 1291, 1156, 1102, 1069, 916, 744, 697. MS (EI, 70 eV) m/z (\%): $278\left(\mathrm{M}^{+}, 2\right), 235$ (6), 187 (43), 170 (100), 144 (21), 143 (40), 130 (22), 115 (11), 106 (70), 91 (76), 65 (11), 51 (4). HRMS (ESI) calcd for $\mathrm{C}_{19} \mathrm{H}_{23} \mathrm{~N}_{2}: 279.1856$, found: 279.1855 .

\section{2'-Azido- $N$-benzyl-2,3,4,5-tetrahydro-[1,1'-biphenyl]-2-amine (S13)}

Cautions: $\mathrm{NaN}_{3}$ is known to release hydrazoic acid, an unstable and very toxic compound, in the presence of acids. See also General Information.

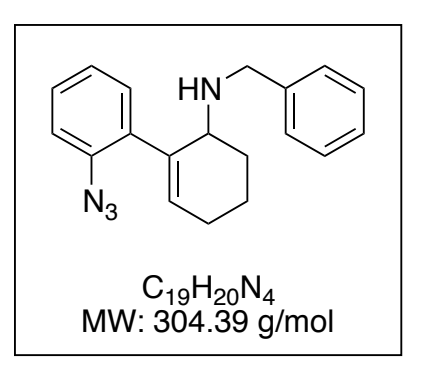

To a solution of $\mathbf{S 1 2}(796 \mathrm{mg}, 2.86 \mathrm{mmol})$ in a $2 \mathrm{~N}$ aqueous $\mathrm{HCl}$ solution $(80 \mathrm{~mL})$ at $0{ }^{\circ} \mathrm{C}$ was added a solution of $\mathrm{NaNO}_{2}(217$ $\mathrm{mg}, 3.14 \mathrm{mmol})$ in water $(8 \mathrm{~mL})$. The reaction mixture was stirred at $0{ }^{\circ} \mathrm{C}$ for $2 \mathrm{~h}$ then a solution of $\mathrm{NaN}_{3}(279 \mathrm{mg}, 4.29$ $\mathrm{mmol})$ in water $(8 \mathrm{~mL})$ was added dropwise. The mixture was stirred at $\mathrm{rt}$ for $2 \mathrm{~h}$. The mixture was then cooled down to $0{ }^{\circ} \mathrm{C}$ and a $25 \% \mathrm{NH}_{4} \mathrm{OH}$ solution was added dropwise until $\mathrm{pH} 11$. The mixture was extracted with $\mathrm{CH}_{2} \mathrm{Cl}_{2}(3 \times 10 \mathrm{~mL})$. The combined organic layers were washed with brine $(1 \times 10$ $\mathrm{mL}$ ), dried over $\mathrm{Na}_{2} \mathrm{SO}_{4}$, filtered, and concentrated under reduced pressure. Purification by flash column chromatography $\left(\mathrm{CH}_{2} \mathrm{Cl}_{2} / \mathrm{MeOH} 99: 1\right)$ gave $\mathbf{S 1 3}(734 \mathrm{mg}, 2.41 \mathrm{mmol}$, $84 \%)$.

Orange oil. ${ }^{1} \mathbf{H}$ NMR (300 MHz, $\left.\mathbf{C D C l}_{3}\right) \delta 7.34-7.26(\mathrm{~m}, 1 \mathrm{H}), 7.23-7.14(\mathrm{~m}, 4 \mathrm{H}), 7.12-$ $7.05(\mathrm{~m}, 2 \mathrm{H}), 7.04-6.99(\mathrm{~m}, 2 \mathrm{H}), 5.75(\mathrm{td}, J=3.8,1.1 \mathrm{~Hz}, 1 \mathrm{H}), 3.70(\mathrm{~d}, J=13.4 \mathrm{~Hz}, 1 \mathrm{H})$, $3.72-3.69(\mathrm{~m}, 1 \mathrm{H}), 3.58(\mathrm{~d}, J=13.4 \mathrm{~Hz}, 1 \mathrm{H}), 2.25-2.08(\mathrm{~m}, 2 \mathrm{H}), 1.90-1.76(\mathrm{~m}, 3 \mathrm{H})$, $1.72-1.60(\mathrm{~m}, 1 \mathrm{H}) .{ }^{13} \mathbf{C}$ NMR (75 MHz, $\left.\mathbf{C D C l}_{3}\right) \delta 140.72,139.00,137.29,134.47,131.17$, 130.58, 128.21, 128.14 (2C), 128.00 (2C), 126.67, 124.73, 118.30, 53.12, 51.00, 28.21, 
25.87, 18.64. IR (neat): 3359 (br), 3023, 2928, 2862, 2117, 2086, 1571, 1483, 1441, 1283, 747, 697. MS (EI, 70 eV) m/z (\%): 170 (6), 169 (61), 168 (100), 167 (51), 166 (10), 139 (7), 115 (4), 83 (20), 77 (5), 63 (3). HRMS (ESI) calcd for $\mathrm{C}_{19} \mathrm{H}_{21} \mathrm{~N}_{4}$ : 305.1761 , found: 305.1758 .

\section{$N$-(2'-Azido-2,3,4,5-tetrahydro-[1,1'-biphenyl]-2-yl)- $N$-benzyl-2-chloroacetamide} (S14)

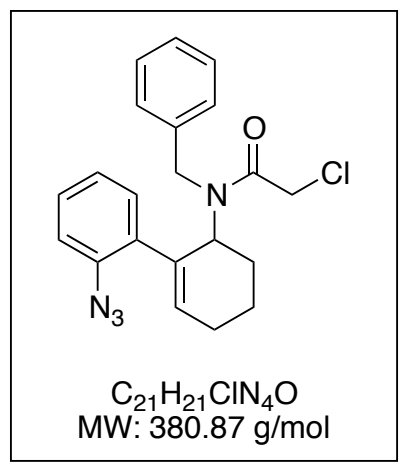

To a solution of $\mathbf{S 1 3}(100 \mathrm{mg}, 0.33 \mathrm{mmol})$ in dry $\mathrm{CH}_{2} \mathrm{Cl}_{2}(1.2$ $\mathrm{mL}$ ) at $\mathrm{rt}$ under argon was added $\mathrm{Et}_{3} \mathrm{~N}$ (55 mixture was cooled down to $0{ }^{\circ} \mathrm{C}$ and chloroacetyl chloride (31 ! $\mathrm{L}, 0.39 \mathrm{mmol}$ ) was added dropwise. The mixture was stirred at $0{ }^{\circ} \mathrm{C}$ for $1 \mathrm{~h}$ then at $\mathrm{rt}$ for $1 \mathrm{~h}$. The mixture was diluted with $\mathrm{CH}_{2} \mathrm{Cl}_{2}(4 \mathrm{~mL})$ and washed with water $(3 \times 4 \mathrm{~mL})$. The organic layer was dried over $\mathrm{Na}_{2} \mathrm{SO}_{4}$, filtered, and concentrated under reduced pressure. Purification by flash column chromatography $\left(\mathrm{CH}_{2} \mathrm{Cl}_{2} /\right.$ pentane $\left.3: 1\right)$ gave $\mathbf{S 1 4}$ contaminated with unidentified side products or the second rotamer $(118 \mathrm{mg}$, $<94 \%)$.

Orange oil. ${ }^{1} \mathbf{H}$ NMR (300 MHz, $\left.\mathbf{C D C l}_{3}\right) \delta 7.33-7.01(\mathrm{~m}, 9 \mathrm{H}), 6.06-6.00(\mathrm{~m}, 1 \mathrm{H}), 5.99-$ $5.90(\mathrm{~m}, 1 \mathrm{H}), 4.38(\mathrm{~d}, J=18.3 \mathrm{~Hz}, 1 \mathrm{H}), 4.18(\mathrm{~d}, J=18.3 \mathrm{~Hz}, 1 \mathrm{H}), 3.56(\mathrm{q}, J=12.2 \mathrm{~Hz}, 2 \mathrm{H})$, 2.23 - $1.55(\mathrm{~m}, 6 \mathrm{H}) .{ }^{13} \mathbf{C}$ NMR (75 MHz, $\left.\mathbf{C D C l}_{3}\right) \delta 168.08,137.85,137.18,135.29,134.54$, 132.33, 129.87, 128.87 (2C), 128.36, 127.32, 125.49 (2C), 124.74, 118.59, 54.17, 47.94, 41.57, 28.15, 25.37, 21.09. IR (in $\mathbf{C D C l}_{3}$ ): 3020, 2933, 2862, 2122, 2096, 1654, 1484, 1442, 1413, 1289, 752, 728, 699. MS (EI, 70 eV) m/z (\%): 345 (2), 317 (12), 316 (44), 288 (7), 260 (5), 225 (17), 197 (13), 183 (24), 170 (34), 143 (7), 115 (11), 91 (100), 65 (9). HRMS (ESI) calcd for $\mathrm{C}_{21} \mathrm{H}_{22} \mathrm{ClN}_{4} \mathrm{O}: 381.1477$, found: 381.1480 .

\section{$N$-(2'-Azido-2,3,4,5-tetrahydro-[1,1'-biphenyl]-2-yl)- $N$-benzyl-2-iodoacetamide}

\section{$((Z)-1 a)$}

To a solution of $\mathbf{S 1 4}$ (98 $\mathrm{mg}, 0.26 \mathrm{mmol}$ ) in acetone (2 $\mathrm{mL}$ ) at rt under argon was added $\mathrm{NaI}$ (96 mg, $0.64 \mathrm{mmol}$ ). The mixture was stirred at rt for $48 \mathrm{~h}$ (caution: flask wrapped in aluminum foil to protect the reaction from light). The solvent was then removed under reduced pressure (caution: flask wrapped in aluminum foil). Purification by flash column chromatography $\left(\mathrm{CH}_{2} \mathrm{Cl}_{2}\right)$ gave $(Z)-\mathbf{1 a}(106 \mathrm{mg}, 0.22 \mathrm{mmol}, 86 \%)$. 


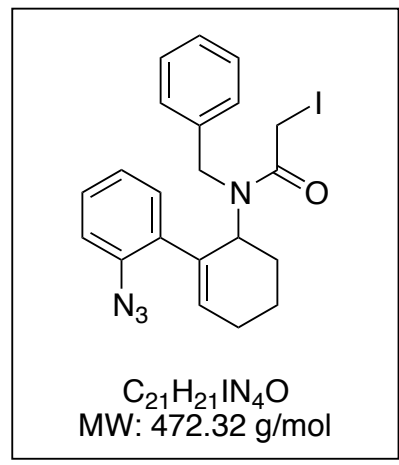

Yellow gum. ${ }^{1} \mathbf{H}$ NMR (300 $\left.\mathbf{M H z}, \mathbf{C D C l}_{3}\right) \delta 7.34-7.03(\mathrm{~m}, 9 \mathrm{H})$, $6.03-5.95(\mathrm{~m}, 2 \mathrm{H}), 4.43(\mathrm{~d}, J=18.3 \mathrm{~Hz}, 1 \mathrm{H}), 4.16(\mathrm{~d}, J=18.3 \mathrm{~Hz}$, $1 \mathrm{H}), 3.35(\mathrm{~d}, J=9.7 \mathrm{~Hz}, 1 \mathrm{H}), 3.21(\mathrm{~d}, J=9.7 \mathrm{~Hz}, 1 \mathrm{H}), 2.21-2.02$ $(\mathrm{m}, 3 \mathrm{H}), 1.82-1.57(\mathrm{~m}, 3 \mathrm{H}) \cdot{ }^{13} \mathrm{C}$ NMR (75 $\left.\mathbf{M H z}, \mathbf{C D C l}_{3}\right) \delta$ $169.21,138.10,137.24,135.46,134.75,132.73,129.86,128.82$ (2C), 128.32, 127.33, 125.30 (2C), 125.09, 118.83, 53.68, 48.79, 28.32, 25.39, 21.06, -2.74. IR (neat): 3020, 2933, 2854, 2121, 2091, 1636, 1484, 1428, 1405, 1290, 1208, 1159, 994, 959, 749, 727, 695. MS (EI, 70 eV) $m / z$ (\%): 317 (15), 316 (48), 288 (10), 260 (7), 225 (24), 197 (17), 183 (28), 170 (42), 143 (10), 115 (16), 91 (100), 65 (11). HRMS (ESI) calcd for $\mathrm{C}_{21} \mathrm{H}_{22} \mathrm{IN}_{4} \mathrm{O}$ : 473.0833, found: 473.0834 . 


\section{3. $\mathbf{N}$-Tosylated derivative}

The allylic alcohol S4 was transformed into the tosylamide S16 via a two-step sequence involving a Mitsunobu reaction followed by the Boc-deprotection, in 59\% yield for the two steps. The nitro moiety of $\mathbf{S 1 6}$ was hydrogenated and the resulting aniline $\mathbf{S 1 7}$ was transformed into the corresponding azido compound $\mathbf{S 1 8}$ upon treatment with tertbutyl nitrite and trimethylsilyl azide ${ }^{3}$ in $72 \%$ for the two steps. The acylation of the tosylamide $\mathbf{S 1 8}$ with bromoacetyl bromide gave the bromoacetamide $\mathbf{S 1 9}$ in $80 \%$ yield, ${ }^{6}$ that was converted to the iodide $\mathbf{1 b}$ by a Finkelstein reaction.
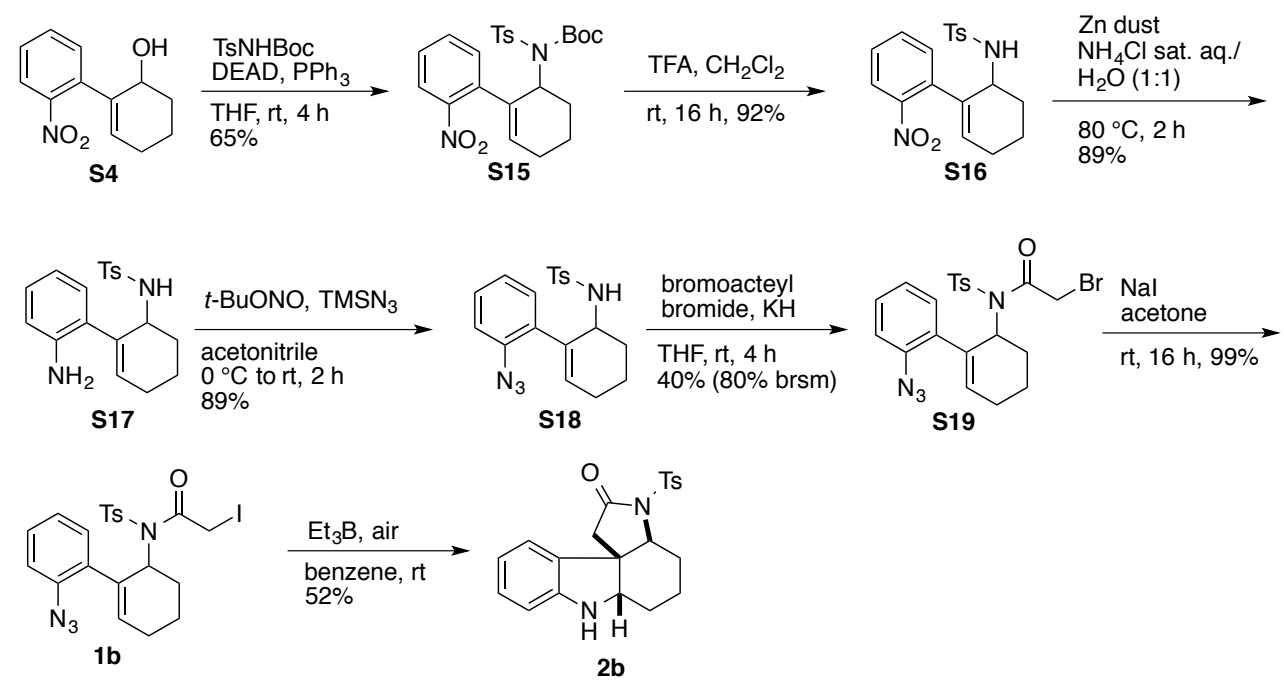

tert-Butyl-(2'-nitro-2,3,4,5-tetrahydro-[1,1'-biphenyl]-2-yl)(tosyl)

carbamate (S15)

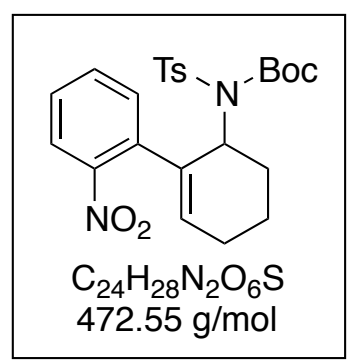

tert-Butyl tosylcarbamate $(2.564,9.45 \mathrm{mmol})$ was dissolved in dry THF (7 mL) and $\mathrm{PPh}_{3}(4.957 \mathrm{~g}, 18.9 \mathrm{mmol})$ was added. The solution was stirred at rt and the allylic alcohol S4 (1.384 g, 6.3 mmol) was added followed by DEAD (2.45 mL, $15.75 \mathrm{mmol}$ ) dropwise. The mixture was stirred for $4 \mathrm{~h}$ until no starting material was left. Then the THF was removed under reduced pressure and the mixture was diluted with EtOAc $(30 \mathrm{~mL})$. The solution was successively washed with $1 \mathrm{M} \mathrm{NaOH}(1 \times 20 \mathrm{~mL})$, water (1 x $20 \mathrm{~mL})$ and brine, dried over $\mathrm{Na}_{2} \mathrm{SO}_{4}$ and concentrated under reduced pressure. The crude was purified by flash column chromatography (pentane/Et $20,2: 1$ ) to give $\mathbf{S 1 5}$ (1.935 g, 65\%).

Yellowish solid. $\mathbf{m}_{\mathbf{p}}: 121.0-121.8{ }^{\circ} \mathrm{C} .{ }^{\mathbf{1}} \mathbf{H}$ NMR (300 $\left.\mathbf{M H z}, \mathbf{C D C l}_{3}\right) \delta 8.05(\mathrm{dd}, J=7.8,1.6$ 
$\mathrm{Hz}, 1 \mathrm{H}), 7.43(\mathrm{~m}, 5 \mathrm{H}), 7.11(\mathrm{~d}, J=8.2 \mathrm{~Hz}, 2 \mathrm{H}), 5.86-5.77(\mathrm{~m}, 1 \mathrm{H}), 5.77-5.61(\mathrm{~m}, 1 \mathrm{H})$, $2.49-2.31(\mathrm{~m}, 1 \mathrm{H}), 2.37$ (s, 3H), $2.30-2.10(\mathrm{~m}, 3 \mathrm{H}), 2.00-1.88(\mathrm{~m}, 2 \mathrm{H}), 1.30$ (s, 9H). ${ }^{13}$ C NMR (75 MHz, $\left.\mathbf{C D C l}_{3}\right) \delta$ 150.25, 148.24, 143.52, 137.68, 136.28, 132.80, 130.25, 128.96 (2C), 128.13, 127.39 (2C), 124.54, 117.47, 84.08, 57.29, 28.42, 27.84, 25.00, 22.24, 21.47. (carbonyl carbon peak missing). IR (neat): 2998, 2937, 1724, 1525, 1344, 1150, 1087, 1005. MS (EI, 70 eV) m/z (\%): 217 (34), 200 (23), 199 (68), 185 (16), 184 (13), 171 (15), 170 (13), 169 (16), 168 (34), 167 (26), 156 (17), 155 (28), 146 (14), 115 (15), 92 (17), 91 (100), 89 (13), 77 (24), 65 (35), 39 (13). HRMS (ESI) calcd for $\mathrm{C}_{24} \mathrm{H}_{28} \mathrm{O}_{6} \mathrm{~N}_{2} \mathrm{NaS}: 495.1560$, found 495.1549 .

\section{4-Methyl- $N$-(2'-nitro-2,3,4,5-tetrahydro-[1,1'-biphenyl]-2-yl)benzenesulfonamide (S16)}

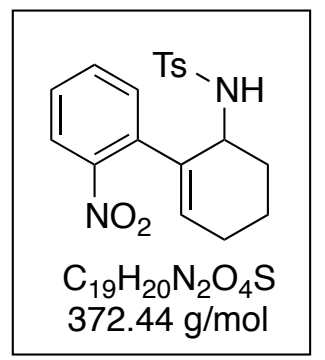

To a stirred solution of tosylcarbamate $\mathbf{S 1 5}$ (1.567 g, $3.3 \mathrm{mmol}$ ) in $\mathrm{CH}_{2} \mathrm{Cl}_{2}(33 \mathrm{~mL})$ was added dropwise TFA (1.27 mL, $\left.16.6 \mathrm{mmol}\right)$. The solution was stirred overnight at rt. The solvent was evaporated under reduced pressure and the crude was purified by flash column chromatography (pentane/Et $2 \mathrm{O}, 4: 1$ to $1: 1$ ) to obtain product $\mathbf{S 1 6}$ (1.14 g, 92\%).

White solid. $\mathbf{m}_{\mathbf{p}}$ : $144.8-146.0{ }^{\circ} \mathrm{C} .{ }^{1} \mathbf{H}$ NMR (300 $\left.\mathbf{~ M H z}, \mathbf{C D C l}_{3}\right) \delta 7.75-7.55(\mathrm{~m}, 1 \mathrm{H}), 7.38$ $(\mathrm{d}, J=8.1 \mathrm{~Hz}, 2 \mathrm{H}), 7.34-7.18(\mathrm{~m}, 2 \mathrm{H}), 7.01-6.88(\mathrm{~m}, 3 \mathrm{H}), 5.66(\mathrm{~s}, 1 \mathrm{H}), 5.21$ (d, J = 6.9 $\mathrm{Hz}, 1 \mathrm{H}), 4.03$ (s, 1H), $2.34(\mathrm{~s}, 3 \mathrm{H}), 2.22-1.96(\mathrm{~m}, 3 \mathrm{H}), 1.96-1.78(\mathrm{~m}, 1 \mathrm{H}), 1.71(\mathrm{~m}, 2 \mathrm{H})$. ${ }^{13}$ C NMR (75 MHz, $\left.\mathbf{C D C l}_{3}\right) \delta$ 149.01, 142.55, 137.31, 135.68, 133.83, 132.27, 132.23, 130.79, 129.30 (2C), 127.62, 126.53 (2C), 123.93, 51.27, 30.88, 25.18, 21.39, 17.04. IR (neat): 3263(br), 2953, 2871, 1516, 1443, 1417, 1351, 1324, 1152. MS (EI, 70 eV) m/z (\%): 217 (37), 200 (23), 199 (69), 171 (18), 170 (16), 169 (24), 168 (46), 167 (34), 158 (15), 156 (21), 155 (36), 146 (19), 130 (19), 128 (16), 115 (20), 92 (17), 91 (100), 77 (25), 65 (42), 39 (15). HRMS (ESI) calcd for $\mathrm{C}_{19} \mathrm{H}_{21} \mathrm{O}_{4} \mathrm{~N}_{2} \mathrm{~S}: 373.1217$, found 373.1211.

\section{$N$-(2'-Amino-2,3,4,5-tetrahydro-[1,1'-biphenyl]-2-yl)-4-methylbenzene- sulfonamide (S17)}

To a solution of nitro compound $\mathbf{S 1 6}(112 \mathrm{mg}, 0.3 \mathrm{mmol})$ in a mixture of EtOH/ $\mathrm{NH}_{4} \mathrm{Cl}$ sat. aq. (1:1, $1 \mathrm{~mL})$ was added zinc dust (98 $\mathrm{mg}, 1.5 \mathrm{mmol})$. The reaction mixture was stirred for $2 \mathrm{~h}$ at $80{ }^{\circ} \mathrm{C}$. Then it was diluted with EtOAc $(10 \mathrm{~mL})$ and $\mathrm{NH}_{3} \cdot \mathrm{H}_{2} \mathrm{O}(1 \mathrm{~mL})$ 


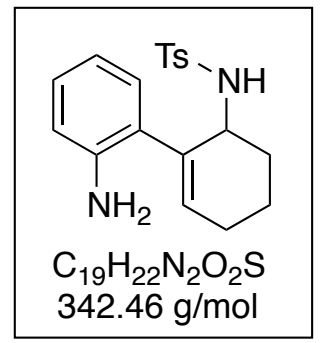

was added. The solid was filtered off over a pad of celite and the filtrate was washed with brine, dried over $\mathrm{Na}_{2} \mathrm{SO}_{4}$ and concentrated under reduced pressure. The residue was purified by flash column chromatography (cyclohexane/EtOAc, 4:1 to 2:1) to get the desired product $\mathbf{S 1 7}$ (91 $\mathrm{mg}, 89 \%$ ).

Yellow solid. $\mathbf{m}_{\mathbf{p}}$ : $97.4-100.7^{\circ} \mathrm{C} .{ }^{1} \mathbf{H}$ NMR (300 $\left.\mathbf{~ M H z}, \mathbf{C D C l}_{3}\right) \delta 7.27-7.25(\mathrm{~m}, 2 \mathrm{H}), 7.04$ - $6.90(\mathrm{~m}, 3 \mathrm{H}), 6.56(\mathrm{~d}, J=7.9 \mathrm{~Hz}, 1 \mathrm{H}), 6.53-6.47(\mathrm{~m}, 2 \mathrm{H}), 5.80(\mathrm{t}, J=3.3 \mathrm{~Hz}, 1 \mathrm{H}), 5.62$ (d, $J=5.0 \mathrm{~Hz}, 1 \mathrm{H}), 3.75(\mathrm{~s}, \mathrm{NH}), 3.59$ (s, NH2), $2.33(\mathrm{~s}, 3 \mathrm{H}), 2.28-1.97(\mathrm{~m}, 3 \mathrm{H}), 1.97-$ 1.63 (m, 3H). ${ }^{13} \mathbf{C}$ NMR (75 MHz, CDCl $\left._{3}\right) \delta 143.19,142.22,136.23,134.94,132.82$, 129.19 (2C), 129.02, 128.01, 127.94, 126.55 (2C), 119.18, 115.83, 52.47, 31.07, 25.29, 21.37, 17.50. IR (neat): 3280, 2936, 1615, 1494, 1447, 1326, 1153. MS (EI, 70 eV) $\mathbf{~ m / z}$ (\%): 187 (21), 172 (9), 171 (22), 170 (100) 169 (3), 168 (9), 158 (6), 155 (5), 144 (9), 143 (47), 142 (3), 132 (3), 130 (9), 117 (4), 115 (4), 106 (4), 91 (15), 77 (5), 65 (8), 56 (3). HRMS (ESI) calcd for $\mathrm{C}_{19} \mathrm{H}_{23} \mathrm{O}_{2} \mathrm{~N}_{2} \mathrm{~S}: 343.1475$, found 343.1486 .

\section{$N$-(2'-Azido-2,3,4,5-tetrahydro-[1,1'-biphenyl]-2-yl)-4-methylbenzene- sulfonamide (S18)}

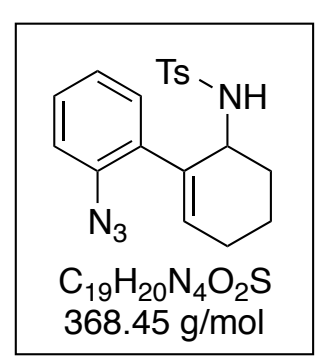

chromatography (pentane/Et $20,4: 1$ ) to get $\mathbf{S 1 8}$ (153 mg, 89\%).

White solid. $\mathbf{m}_{\mathbf{p}}: 156.6-158.3{ }^{\circ} \mathrm{C} .{ }^{\mathbf{1}} \mathbf{H}$ NMR (300 $\left.\mathbf{M H z} \mathbf{C D C l}_{3}\right) \delta 7.35(\mathrm{~d}, J=8.3 \mathrm{~Hz}, 2 \mathrm{H})$, $7.24-7.13(\mathrm{~m}, 1 \mathrm{H}), 7.07-6.82(\mathrm{~m}, 4 \mathrm{H}), 6.73(\mathrm{dd}, J=8.0,0.7 \mathrm{~Hz}, 1 \mathrm{H}), 5.72(\mathrm{t}, J=3.6 \mathrm{~Hz}$, $1 \mathrm{H}), 4.52(\mathrm{~d}, J=6.6 \mathrm{~Hz}, 1 \mathrm{H}), 4.14(\mathrm{~d}, J=4.2 \mathrm{~Hz}, 1 \mathrm{H}), 2.37(\mathrm{~s}, 3 \mathrm{H}), 2.26-1.99(\mathrm{~m}, 3 \mathrm{H}), 1.96$ - $1.79(\mathrm{~m}, 1 \mathrm{H}), 1.79-1.64(\mathrm{~m}, 2 \mathrm{H}) .{ }^{13} \mathbf{C} \mathbf{~ N M R}\left(75 \mathbf{M H z}, \mathbf{C D C l}_{3}\right) \delta 142.54,137.01,136.80$, 135.05, 133.38, 132.46, 131.05, 129.17 (2C), 128.32, 126.78 (2C), 124.65, 117.85, 50.48, 30.56, 25.31, 21.44, 16.94. IR (neat): 3268 (br), 2937 (br), 2121, 1486, 1442, 1327, 1283, 1156. MS (EI, $70 \mathrm{eV}$ ) $\mathbf{m} / \mathbf{z}(\%)$ : the product completely decomposed during the analysis, no detection possible. HRMS (ESI) calcd for $\mathrm{C}_{19} \mathrm{H}_{20} \mathrm{O}_{2} \mathrm{~N}_{4} \mathrm{NaS} 391.1199$, found 391.1196. 


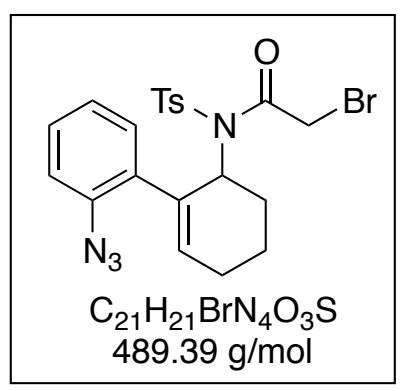

(S19)

To a suspension of potassium hydride (30\% in oil) (220 mg, $1.625 \mathrm{mmol})$ in dry THF (1 mL) was added dropwise a solution of azido-toluenesulfonamide $\mathbf{S 1 8}$ (240 $\mathrm{mg}, 0.65 \mathrm{mmol}$ ) in dry THF (2.5 mL) and the mixture was stirred for $3 \mathrm{~h}$ at $\mathrm{rt}$. Then bromoacetyl bromide ( $60 \mu \mathrm{L}, 0.65 \mathrm{mmol})$ was added and it was

stirred for $1 \mathrm{~h}$ followed by another two additions of bromoacetyl bromide (2 x $60 \mu \mathrm{L}$, $0.65 \mathrm{mmol}$ ) ( $1 \mathrm{~h}$ stirring in between). After stirring overnight the mixture was quenched with EtOAc (10 mL) and water ( $5 \mathrm{~mL})$. The two phases were separated and the aqueous layer was extracted with EtOAc ( $3 \times 10 \mathrm{~mL})$. The combined organic layers were washes sequentially with water and brine, dried over $\mathrm{Na}_{2} \mathrm{SO}_{4}$ and concentrated under reduced pressure to give crude. The crude was purified by flash column chromatography (pentane/Et $2 \mathrm{O}, 7: 1$ for product, resp. 1:1 for recovered starting material) to get $\mathbf{S 1 9}$ (126 mg, 40\%, >80\% brsm).

Gray solid. $\mathbf{m}_{\mathbf{p}}: 101.1-101.8{ }^{\circ} \mathrm{C} .{ }^{\mathbf{1}} \mathbf{H}$ NMR (300 $\left.\mathbf{M H z}, \mathbf{C D C l}_{3}\right) \delta 7.53(\mathrm{~d}, J=8.4 \mathrm{~Hz}, 2 \mathrm{H})$, $7.27-7.22(\mathrm{~m}, 3 \mathrm{H}), 7.02(\mathrm{dd}, J=7.7,5.3 \mathrm{~Hz}, 2 \mathrm{H}), 6.87(\mathrm{~d}, J=8.0 \mathrm{~Hz}, 1 \mathrm{H}), 5.80-5.71(\mathrm{~m}$, $1 \mathrm{H}$ ), $5.37(\mathrm{~s}, 1 \mathrm{H}$ ), 4.23 (A part of AB system, $J=13.7 \mathrm{~Hz}, 1 \mathrm{H}$ ), 3.93 (B part of AB system, $J$ $=13.7 \mathrm{~Hz}, 1 \mathrm{H}), 2.44(\mathrm{~s}, 3 \mathrm{H}), 2.41-2.09(\mathrm{~m}, 4 \mathrm{H}), 2.02-1.87(\mathrm{~m}, 1 \mathrm{H}), 1.87-1.70(\mathrm{~m}, 1 \mathrm{H})$. ${ }^{13}$ C NMR (75 MHz, $\left.\mathbf{C D C l}_{3}\right) \delta 165.49,144.95,137.35,135.73,134.65,132.34,131.81$, 131.29, 129.85 (2C), 128.57, 127.69 (2C), 124.67, 117.71, 59.51, 31.12, 28.10, 24.95, 22.35, 21.62. IR (neat): 3061 (br), 2947 (br), 2127, 1701, 1358, 1292, 1169. MS (EI, 70 eV) $\mathbf{m} / \mathbf{z}(\%): 151$ (3), 136 (20), 135 (4). 134 (22), 123 (22), 121 (24), 108 (4), 107 (4), 106 (5), 95 (12), 93 (13), 71 (5), 56 (6), 55 (100), 54 (16), 53 (5), 43 (8), 42 (14), 41 (13), 39 (9). HRMS (ESI) calcd for $\mathrm{C}_{21} \mathrm{H}_{21} \mathrm{O}_{3} \mathrm{~N}_{4} \mathrm{BrNaS} 511.0410$, found 511.0405 .

\section{$N$-(2'-Azido-2,3,4,5-tetrahydro-[1,1'-biphenyl]-2-yl)-2-iodo- $N$-tosyl-acetamide}

\section{(1b)}

A mixture of tosylacetamide $\mathbf{S 1 9}$ (48 $\mathrm{mg}, 0.1 \mathrm{mmol}$ ) and sodium iodide (38 $\mathrm{mg}, 0.25$ $\mathrm{mmol})$ in acetone $(1 \mathrm{~mL})$ was stirred at $\mathrm{rt}$ for $16 \mathrm{~h}$ (caution: flask wrapped in aluminum foil). The acetone was then removed (caution: flask wrapped in aluminum foil). and the residue was diluted with water $(10 \mathrm{~mL})$ and $\mathrm{CH}_{2} \mathrm{Cl}_{2}(10 \mathrm{~mL})$ and the aqueous layer was extracted with $\mathrm{CH}_{2} \mathrm{Cl}_{2}(3 \times 10 \mathrm{~mL})$. The organic layers were washed sequentially with 


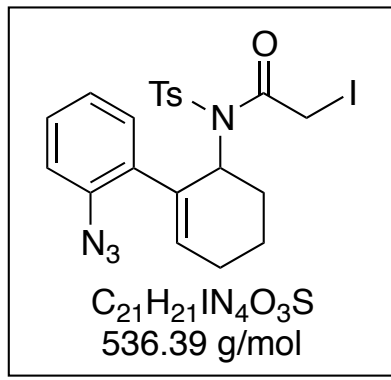

water, $\mathrm{Na}_{2} \mathrm{~S}_{2} \mathrm{O}_{3}$ sat. aq. and brine. The organic phase was then dried over $\mathrm{Na}_{2} \mathrm{SO}_{4}$ and concentrated under reduced pressure to give a clean crude $\mathbf{1 b}$ (53 $\mathrm{mg}$, 99\%), which was used without further purification.

Yellowish solid. ${ }^{1} \mathbf{H}$ NMR (300 $\left.\mathbf{M H z}, \mathbf{C D C l}_{3}\right) \delta 7.55(\mathrm{~d}, J=8.4 \mathrm{~Hz}$, 2H), $7.31-7.20(\mathrm{~m}, 3 \mathrm{H}), 7.04(\mathrm{~d}, J=4.7 \mathrm{~Hz}, 2 \mathrm{H}), 6.92(\mathrm{~d}, J=8.0 \mathrm{~Hz}, 1 \mathrm{H}), 5.82-5.71(\mathrm{~m}$, $1 \mathrm{H}$ ), 5.49 (s, 1H), 4.06 (A part of AB system, $J=11.9 \mathrm{~Hz}, 1 \mathrm{H}$ ), 3.89 (B part of AB system, $J$ $=11.9 \mathrm{~Hz}, 1 \mathrm{H}), 2.44(\mathrm{~s}, 3 \mathrm{H}), 2.37-2.12(\mathrm{~m}, 4 \mathrm{H}), 1.93(\mathrm{~s}, 1 \mathrm{H}), 1.88-1.73(\mathrm{~m}, 1 \mathrm{H})$.

\section{3-Tosyl-3a,4,5,6,6a,7-hexahydro-1H-pyrrolo[2,3-d]carbazol-2(3H)-one (2b)}

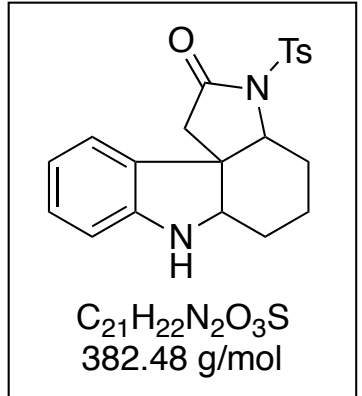

To a solution of aryl azide $\mathbf{1 b}(53 \mathrm{mg}, 0.1 \mathrm{mmol})$ was added $\mathrm{Et}_{3} \mathrm{~B}$ (1 $\mathrm{M}$ in $n$-hexane, $0.1 \mathrm{~mL}, 0.1 \mathrm{mmol}$ ) at rt. The mixture was stirred for $1 \mathrm{~h}$ and another portion of $\mathrm{Et}_{3} \mathrm{~B}$ (1 $\mathrm{M}$ in $n$-hexane, 0.1 $\mathrm{mL}, 0.1 \mathrm{mmol}$ ) was added. This was repeated once (in total 0.3 mmol of $\mathrm{Et}_{3} \mathrm{~B}$ ) and after $3 \mathrm{~h}$ stirring, the reaction was complete. The reaction mixture was filtered over a pad of neutral aluminium oxide, rinsed with $\mathrm{Et}_{2} \mathrm{O}$ and concentrated under reduced pressure. The residue was purified by flash column chromatography (cyclohexane/EtOAc, 4:1) to get the desired product $\mathbf{2 b}$ (20 $\mathrm{mg}, 52 \%)$ as well as a side product 8 (7 mg, 21\%)

White solid. $\mathbf{m}_{\mathbf{p}}: 208.5-209.4{ }^{\circ} \mathrm{C} .{ }^{1} \mathbf{H}$ NMR (300 MHz, $\left.\mathbf{C D C l}_{3}\right) \delta 7.81(\mathrm{~d}, J=8.4 \mathrm{~Hz}, 2 \mathrm{H})$, $7.30(\mathrm{~d}, J=8.0 \mathrm{~Hz}, 2 \mathrm{H}), 7.03(\mathrm{td}, J=7.7,1.1 \mathrm{~Hz}, 1 \mathrm{H}), 6.66(\mathrm{~d}, J=7.8 \mathrm{~Hz}, 1 \mathrm{H}), 6.43(\mathrm{td}, J=$ 7.4, $0.9 \mathrm{~Hz}, 1 \mathrm{H}), 6.30$ (dd, J = 7.4, $0.7 \mathrm{~Hz}, 1 \mathrm{H}), 3.90$ (dd, $J=11.6,5.7 \mathrm{~Hz}, 1 \mathrm{H}), 3.82(\mathrm{~s}, 1 \mathrm{H})$, $3.76(\mathrm{~s}, 1 \mathrm{H}$ ), 2.82 (A part of the AB system, $J=17.0 \mathrm{~Hz}, 1 \mathrm{H}$ ), 2.47 (s, 3H), 2.47 (B part of the AB system, $J=17.0 \mathrm{~Hz}, 1 \mathrm{H}), 2.00-1.88(\mathrm{~m}, 1 \mathrm{H}), 1.88-1.70(\mathrm{~m}, 1 \mathrm{H}), 1.70-1.52(\mathrm{~m}$, 3H), 1.47 - $1.28(\mathrm{~m}, 1 \mathrm{H}) .{ }^{13} \mathbf{C}$ NMR (75 MHz, $\left.\mathbf{C D C l}_{3}\right) \delta 171.33,148.82,144.98,135.31$, 134.81, 129.38 (2C), 128.54, 128.50 (2C), 121.39, 119.23, 109.78, 66.68, 62.23, 46.28, 38.99, 30.35, 25.86, 21.68, 17.29. IR (neat): 1734, 1359, 1169, 1090, 734, 667, 618. HRMS (ESI) calcd for $\mathrm{C}_{21} \mathrm{H}_{23} \mathrm{O}_{3} \mathrm{~N}_{2} \mathrm{~S} 383.1424$, found 383.1317. 
Side Product 8:

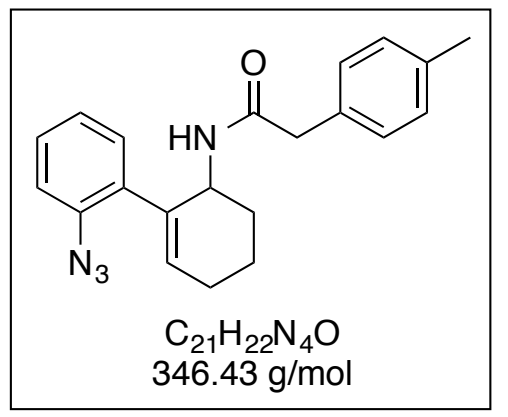

${ }^{1}$ H NMR (300 MHz, $\left.\mathbf{C D C l}_{3}\right) \delta 7.33-7.22(\mathrm{~m}, 2 \mathrm{H}), 7.10-$ $6.91(\mathrm{~m}, 4 \mathrm{H}), 6.80(\mathrm{~d}, J=7.8 \mathrm{~Hz}, 2 \mathrm{H}), 5.71(\mathrm{~s}, 1 \mathrm{H}), 5.33(\mathrm{~s}$, $1 \mathrm{H}), 4.81(\mathrm{~s}, 1 \mathrm{H}), 3.44-3.21(\mathrm{~m}, 2 \mathrm{H}), 2.34(\mathrm{~s}, 3 \mathrm{H}), 2.20-$ $1.83(\mathrm{~m}, 2 \mathrm{H}), 1.83-1.43(\mathrm{~m}, 4 \mathrm{H}) .{ }^{13} \mathrm{C}$ NMR (75 MHz, $\left.\mathbf{C D C l}_{3}\right) \delta 170.43,137.50,136.79,135.29,133.21,132.06$, $131.52,130.35,129.57$ (2C), 129.21 (2C), 128.32, 124.58, 118.03, 47.74, 43.44, 29.72, 25.31, 21.10, 18.91. IR (neat): 2123, 1642, 1512, 1287, 752, 669. MS (EI, 70 eV) m/z (\%): 382 (2, M+), 345 (16), 329 (4), 281 (5), 207 (27), 195 (3), 170 (20), 169 (100), 168 (98), 167 (42), 166 (6) 154 (11), 149 (6), 143 (3), 140 (3), 139 (4), 133 (3), 115 (3), 106 (8), 105 (18), 103 (3). HRMS (ESI) calcd for $\mathrm{C}_{21} \mathrm{H}_{23} \mathrm{ON}_{4}$ 347.1866, found 347.1875.

\section{References}

(1) Banwell, M. G.; Kelly, B. D.; Kokas, O. J.; Lupton, D. W. Org. Lett. 2003, 5, 2497.

(2) Luche, J. L. J. Am. Chem. Soc. 1978, 100, 2226.

(3) Barral, K.; Moorhouse, A. D.; Moses, J. E. Org. Lett. 2007, 9, 1809.

(4) Krafft, M. E.; Cran, J. W. Synlett 2005, 1263.

(5) Chen, J.; Forsyth, C. J. J. Am. Chem. Soc. 2003, 125, 8734.

(6) brsm = based on recovered starting material

\section{NMR Spectra}




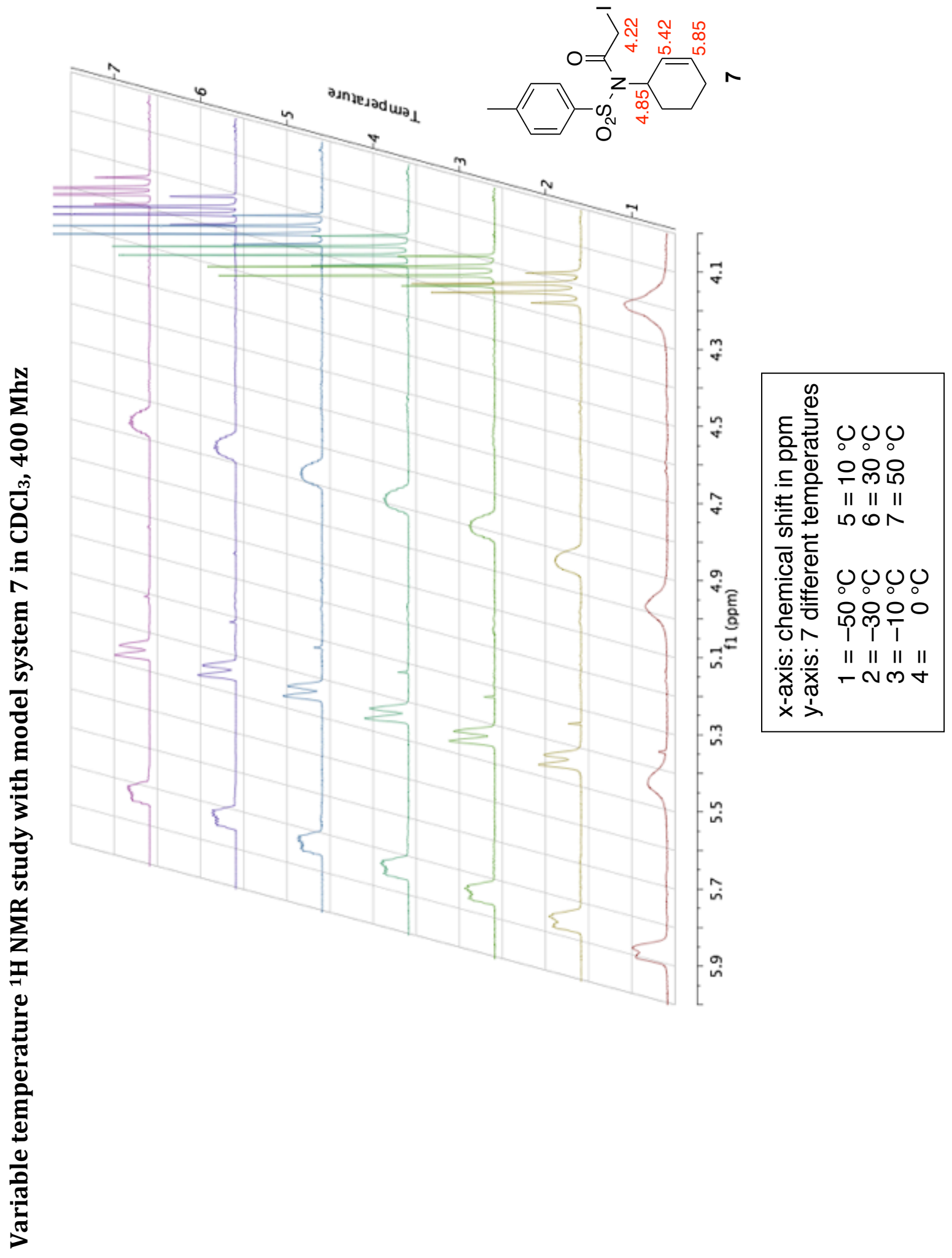




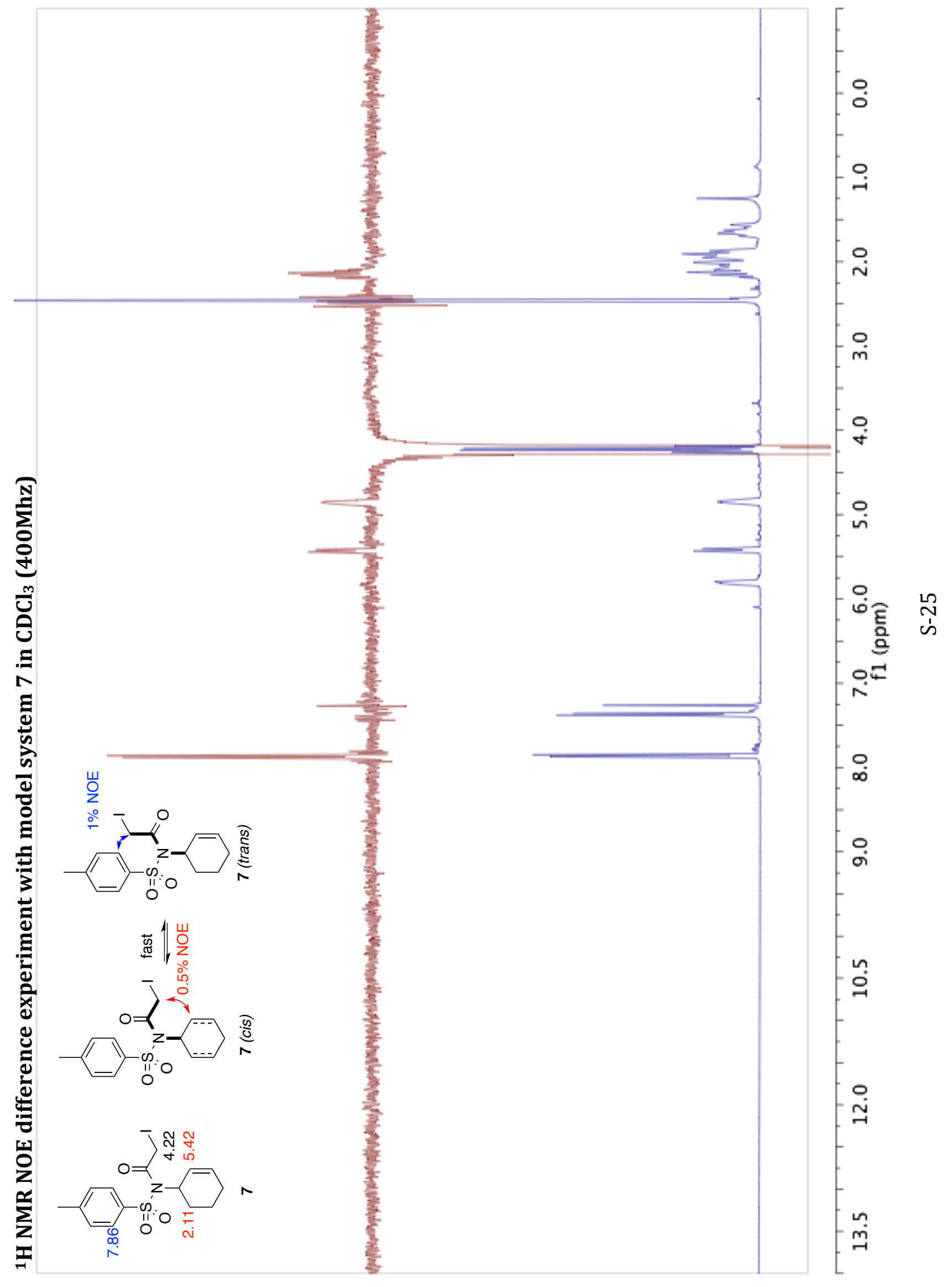



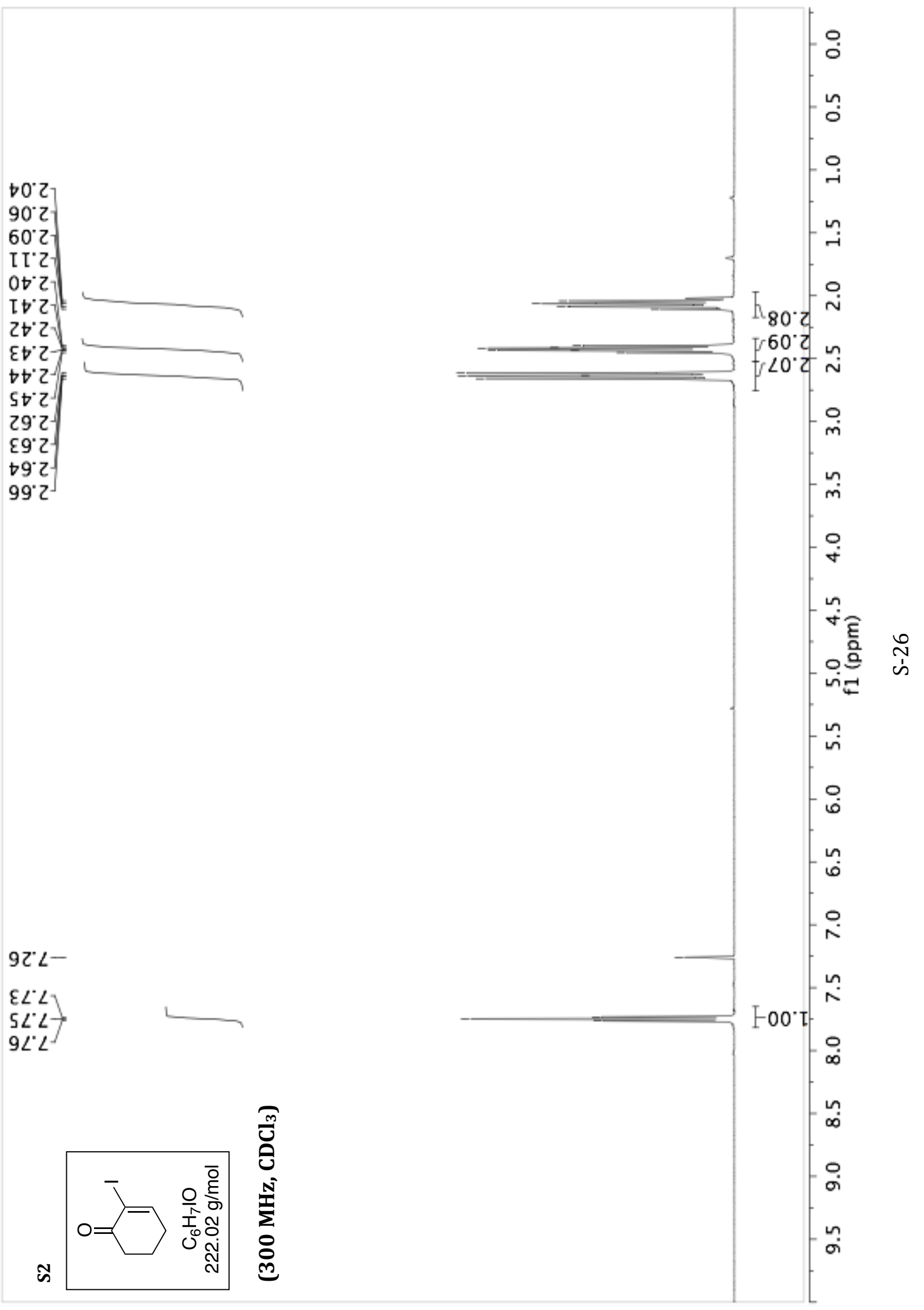


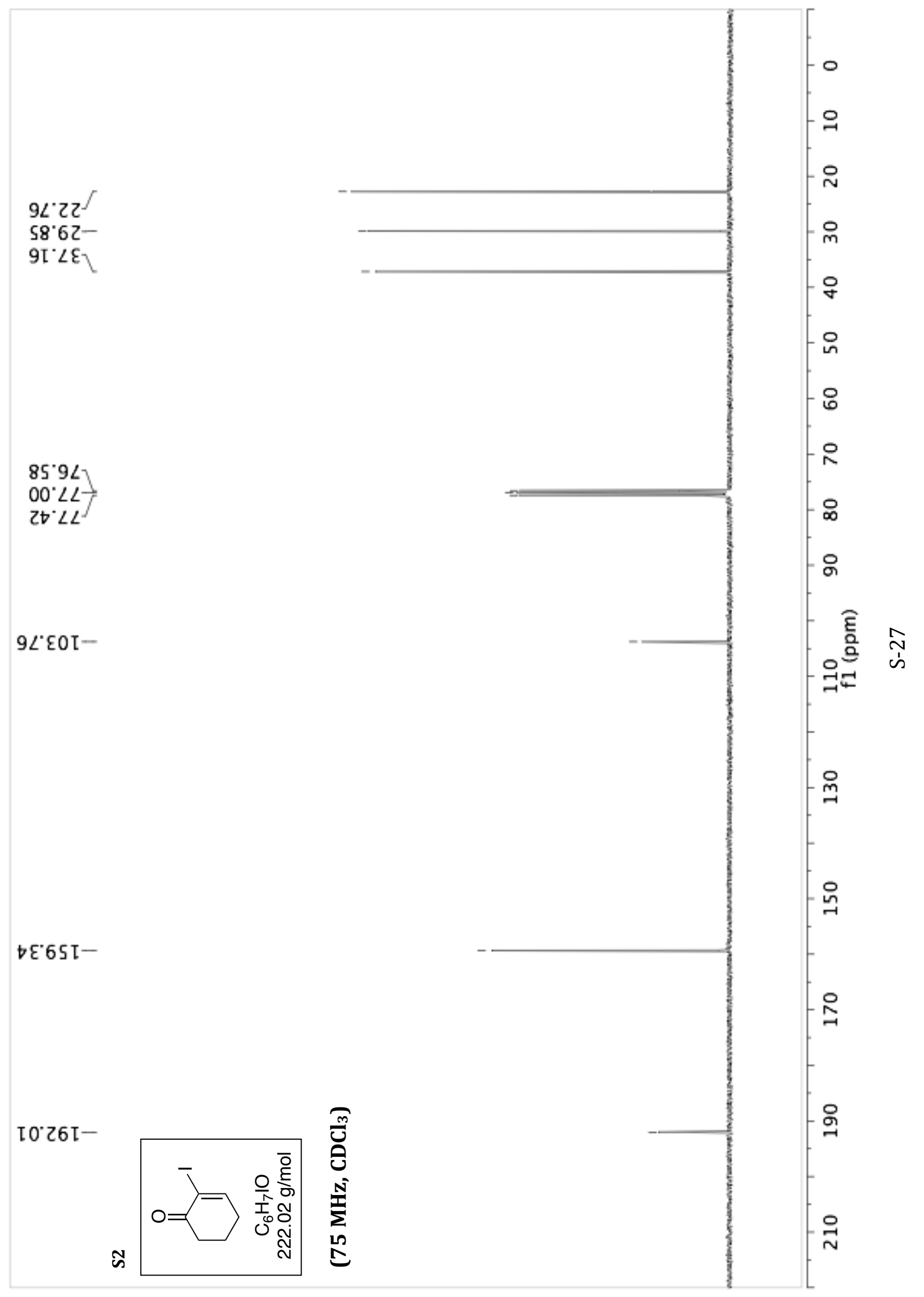



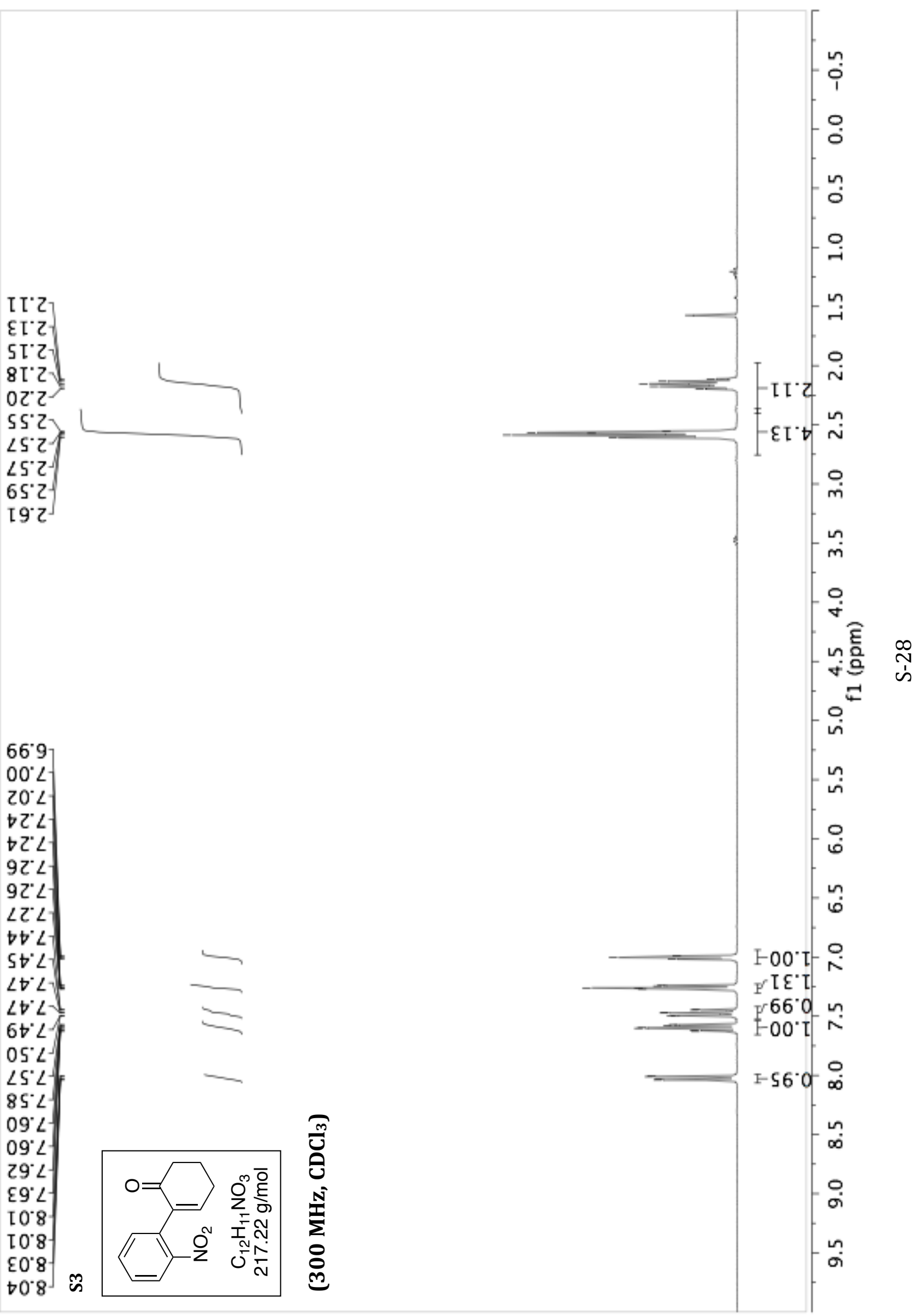


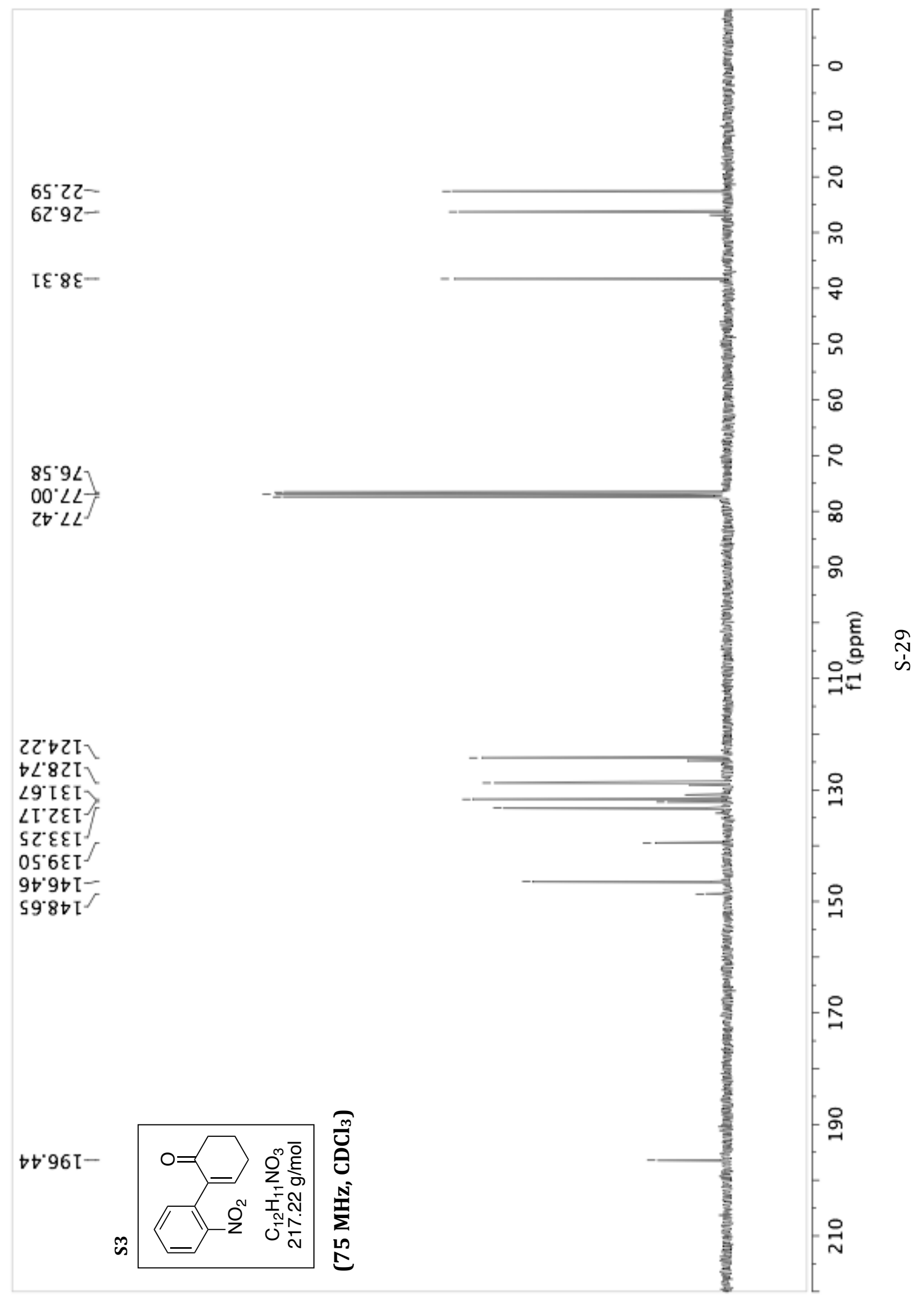



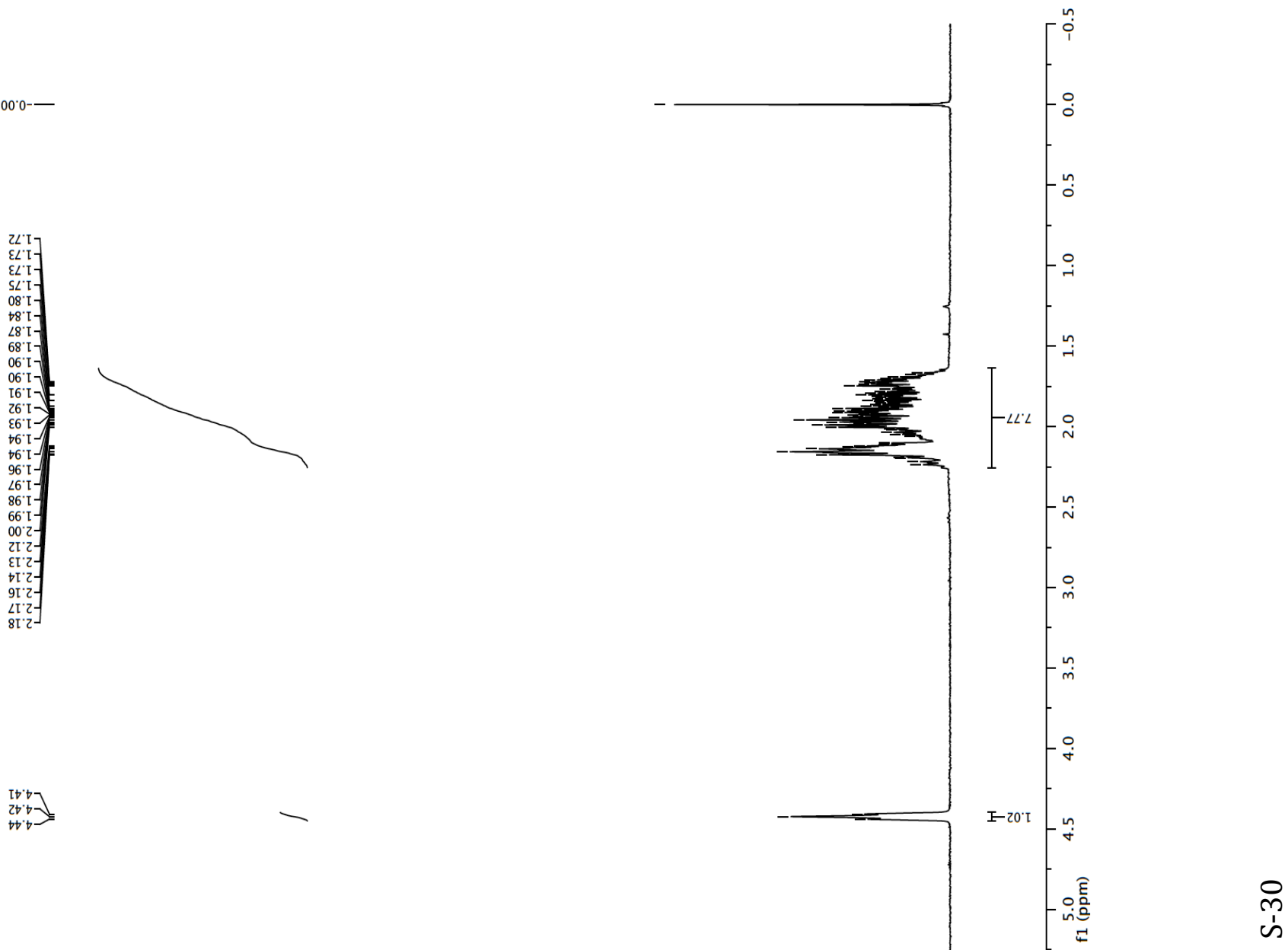

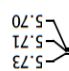

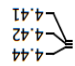

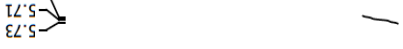

iे

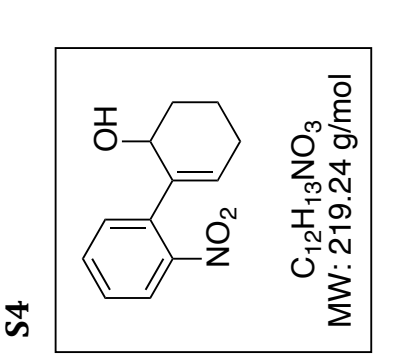

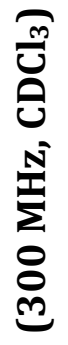

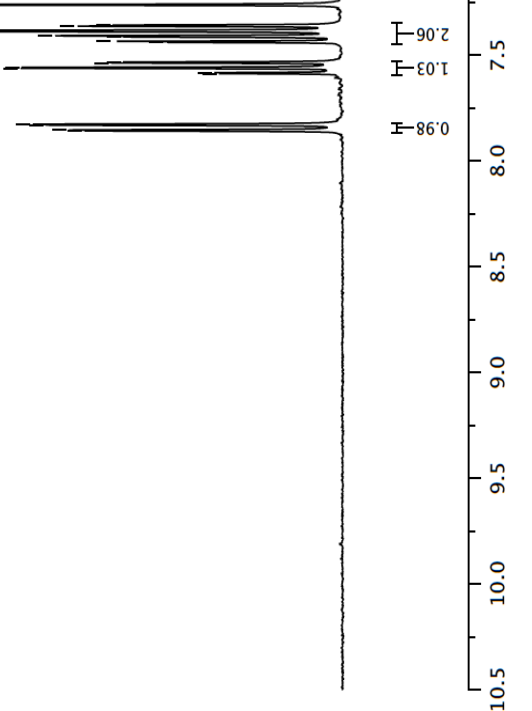




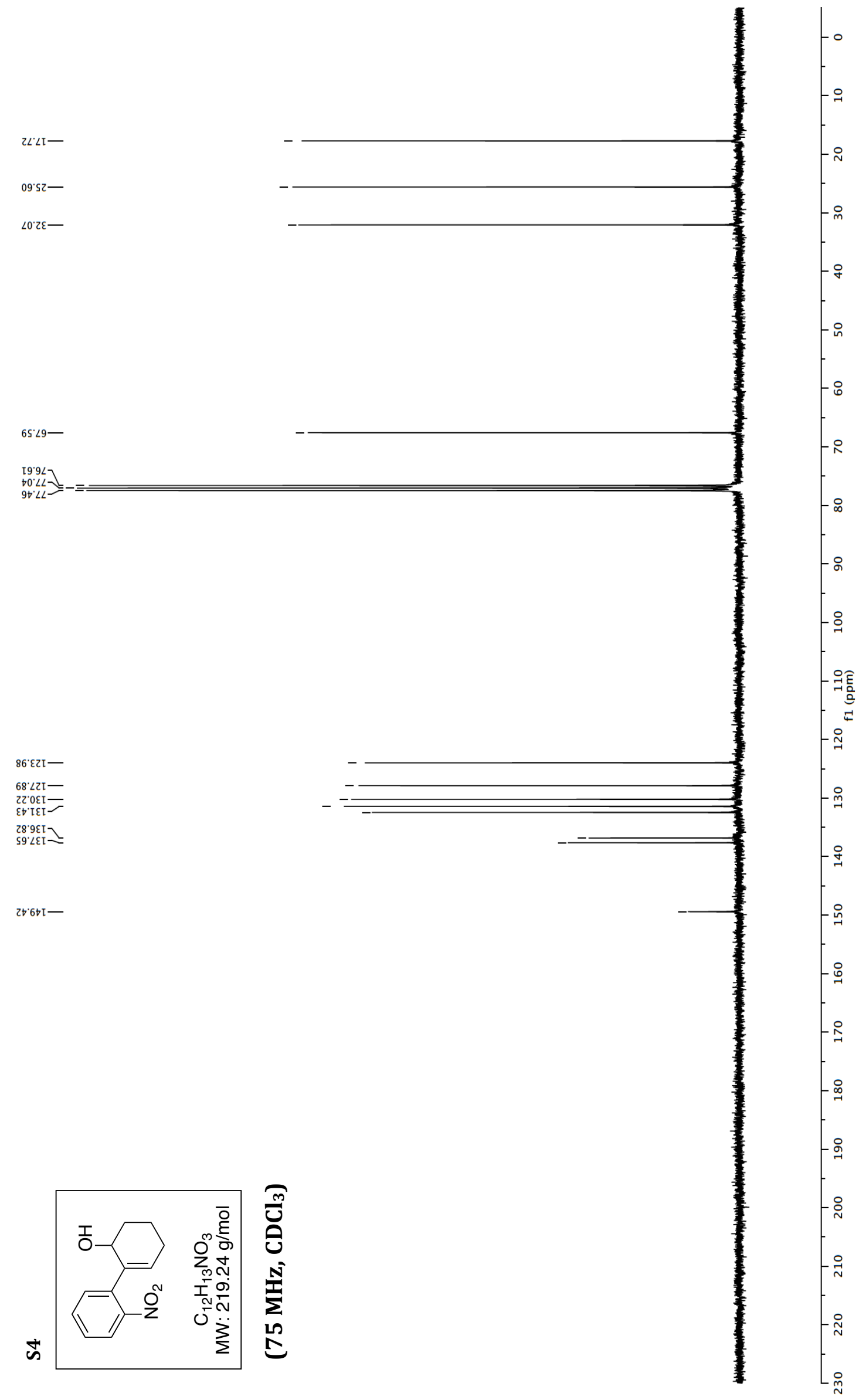




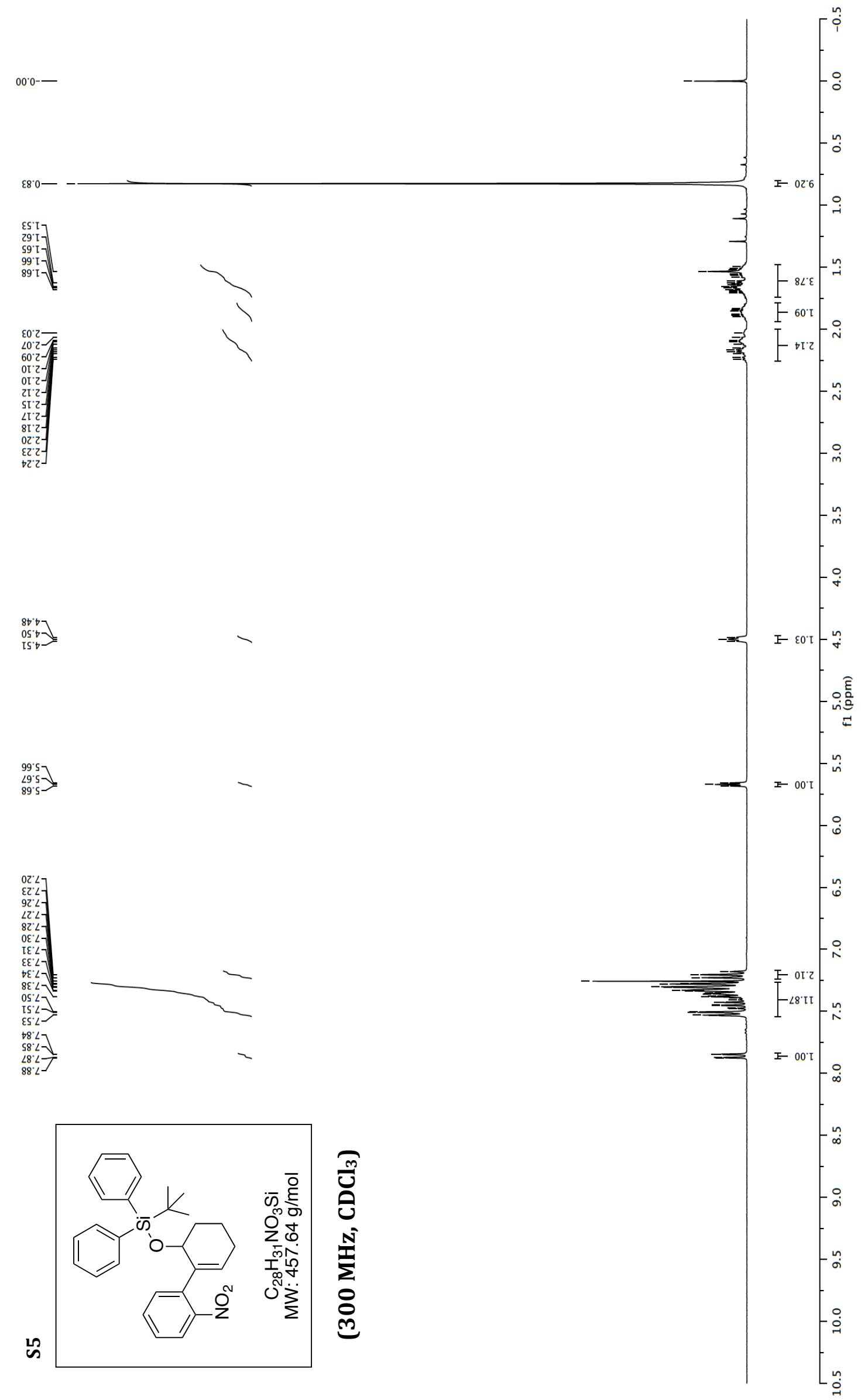




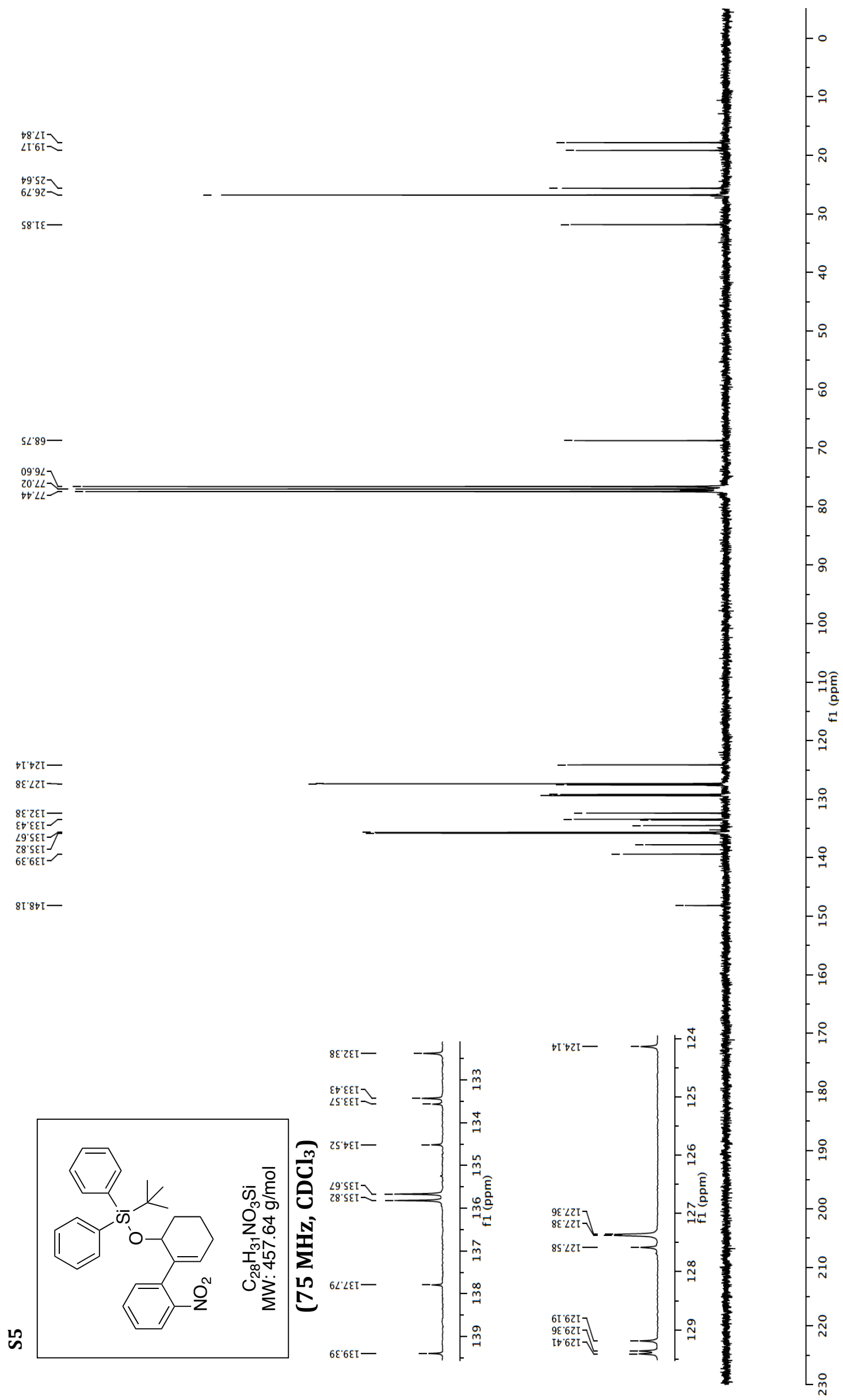




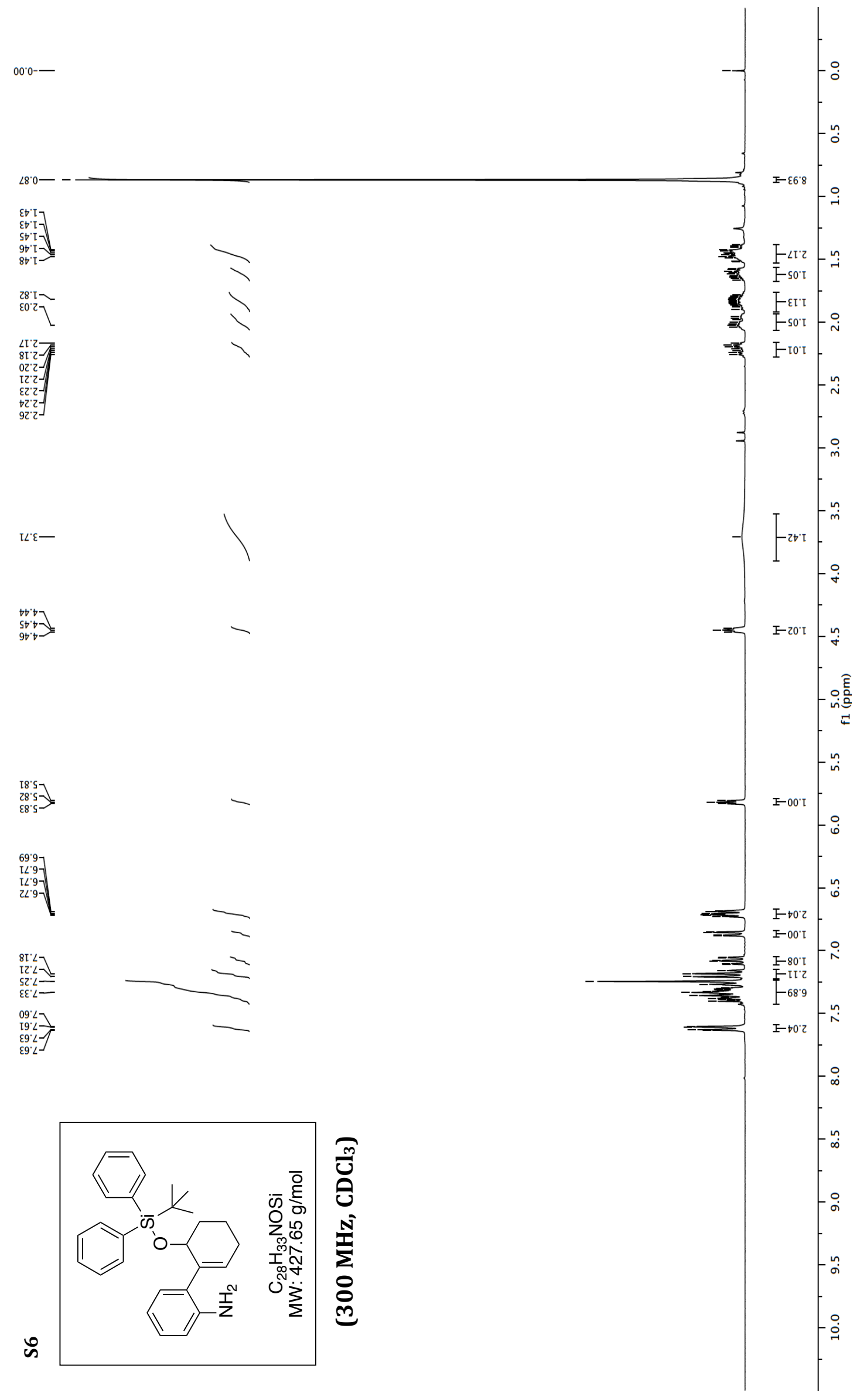




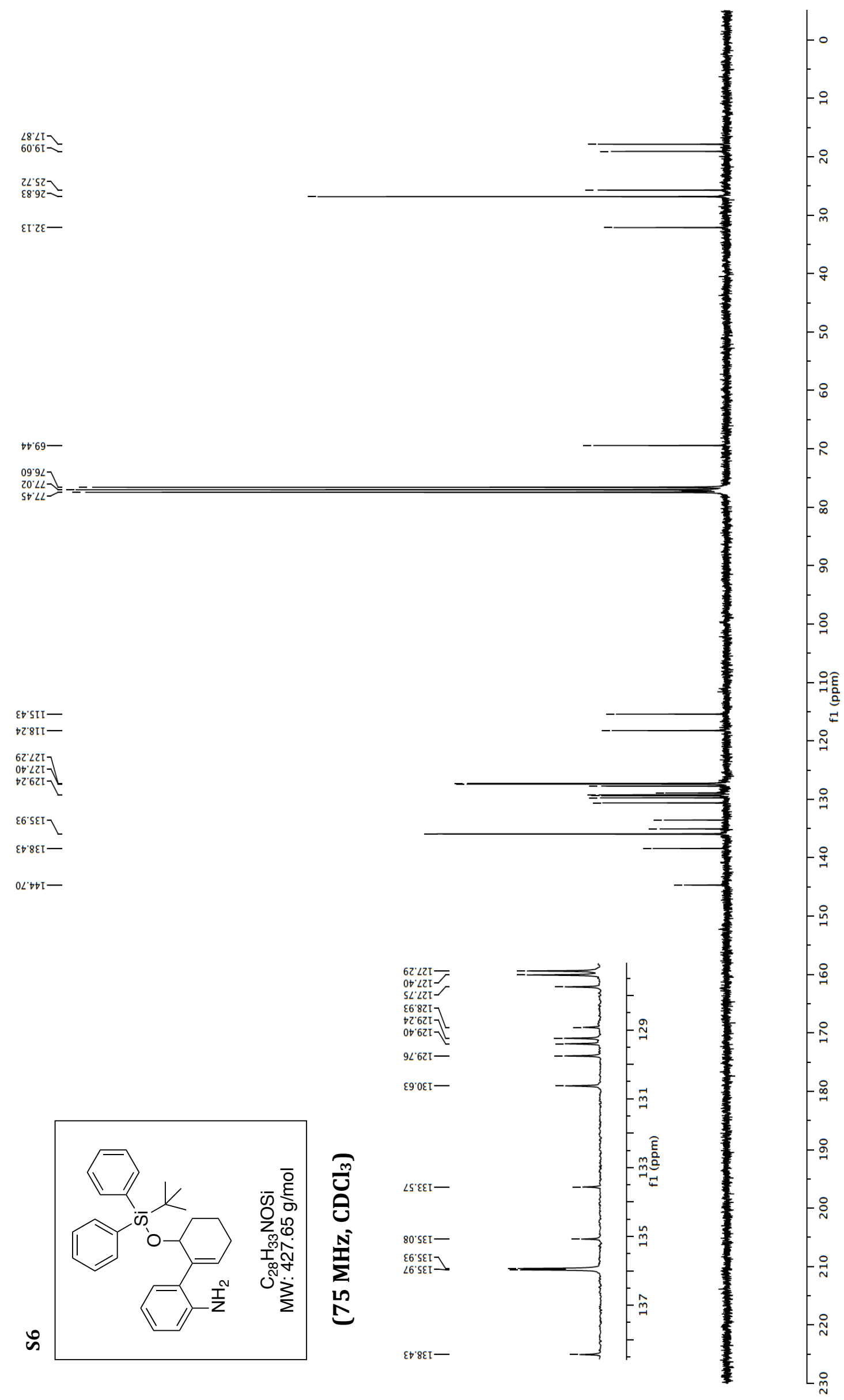

ஸे 


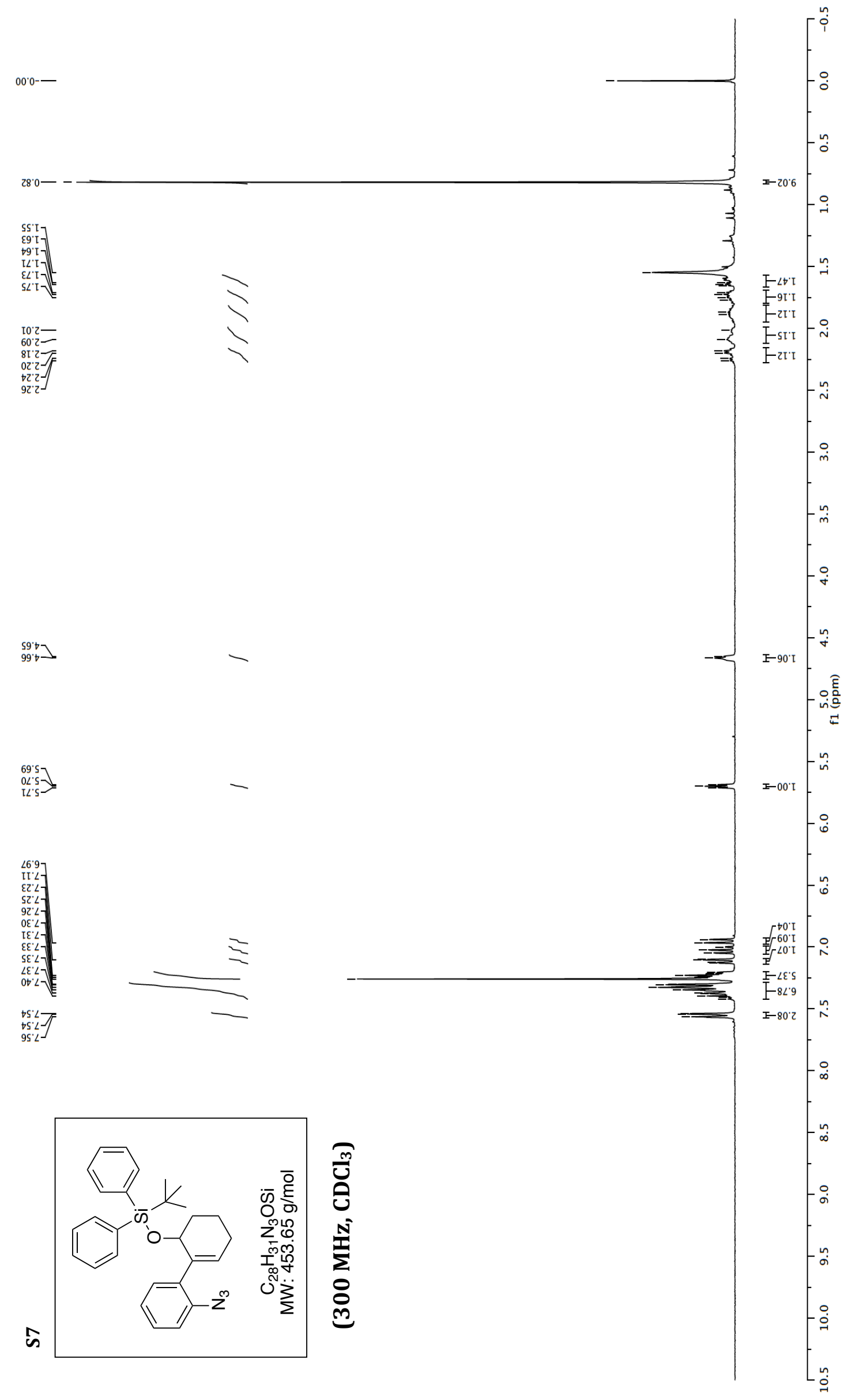




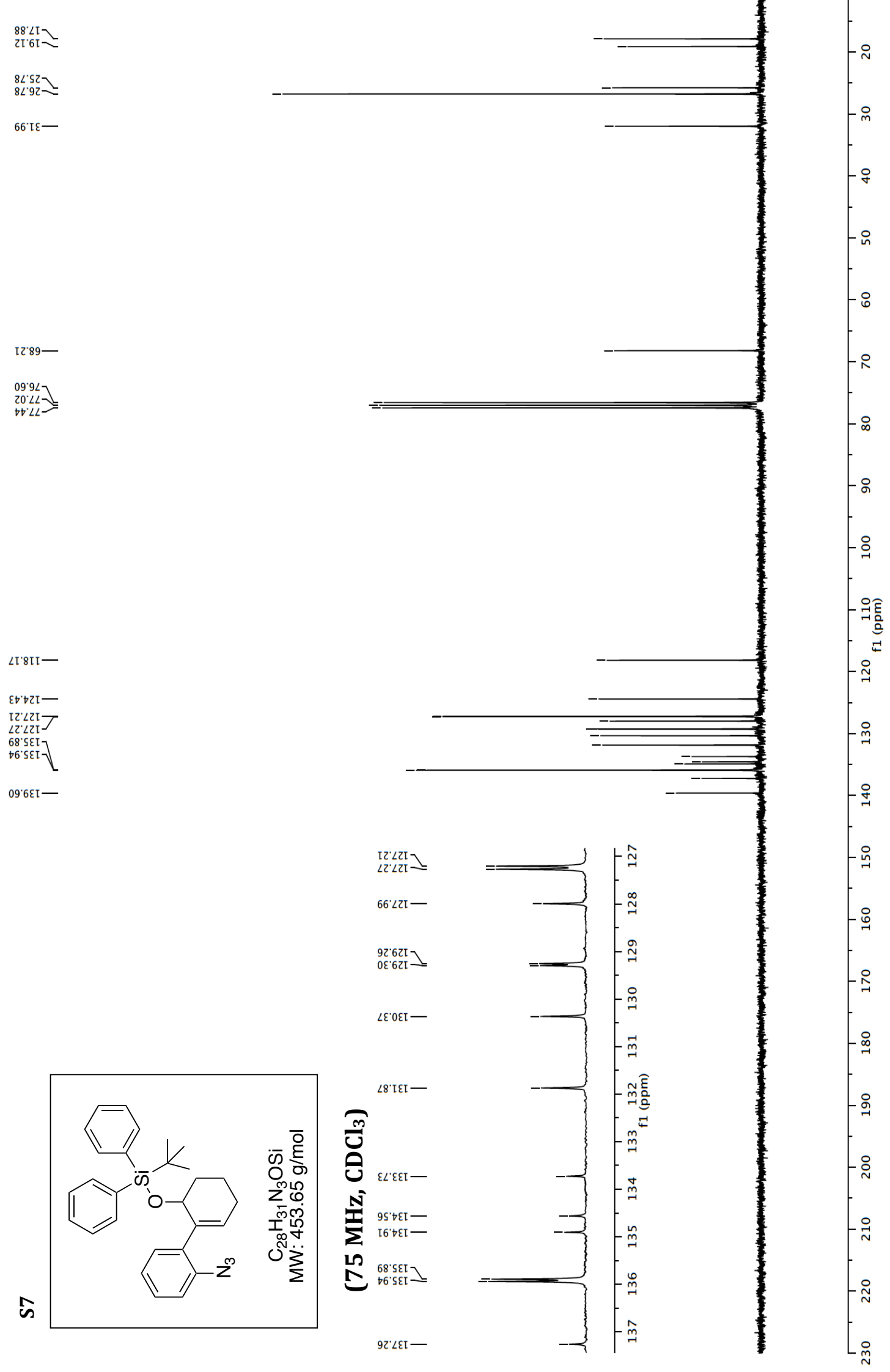




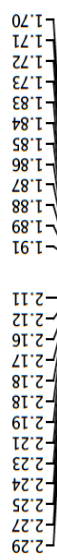

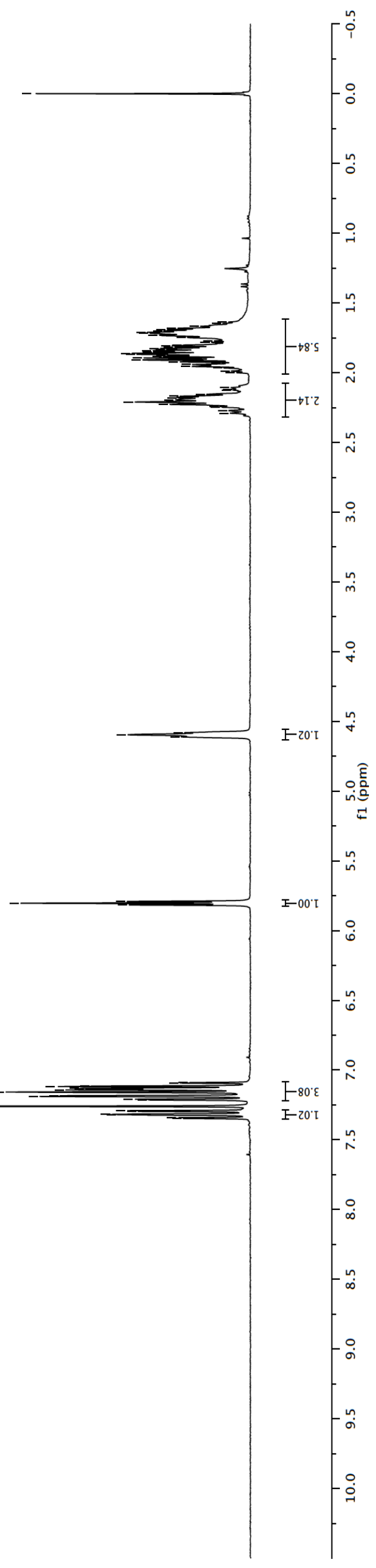

in 


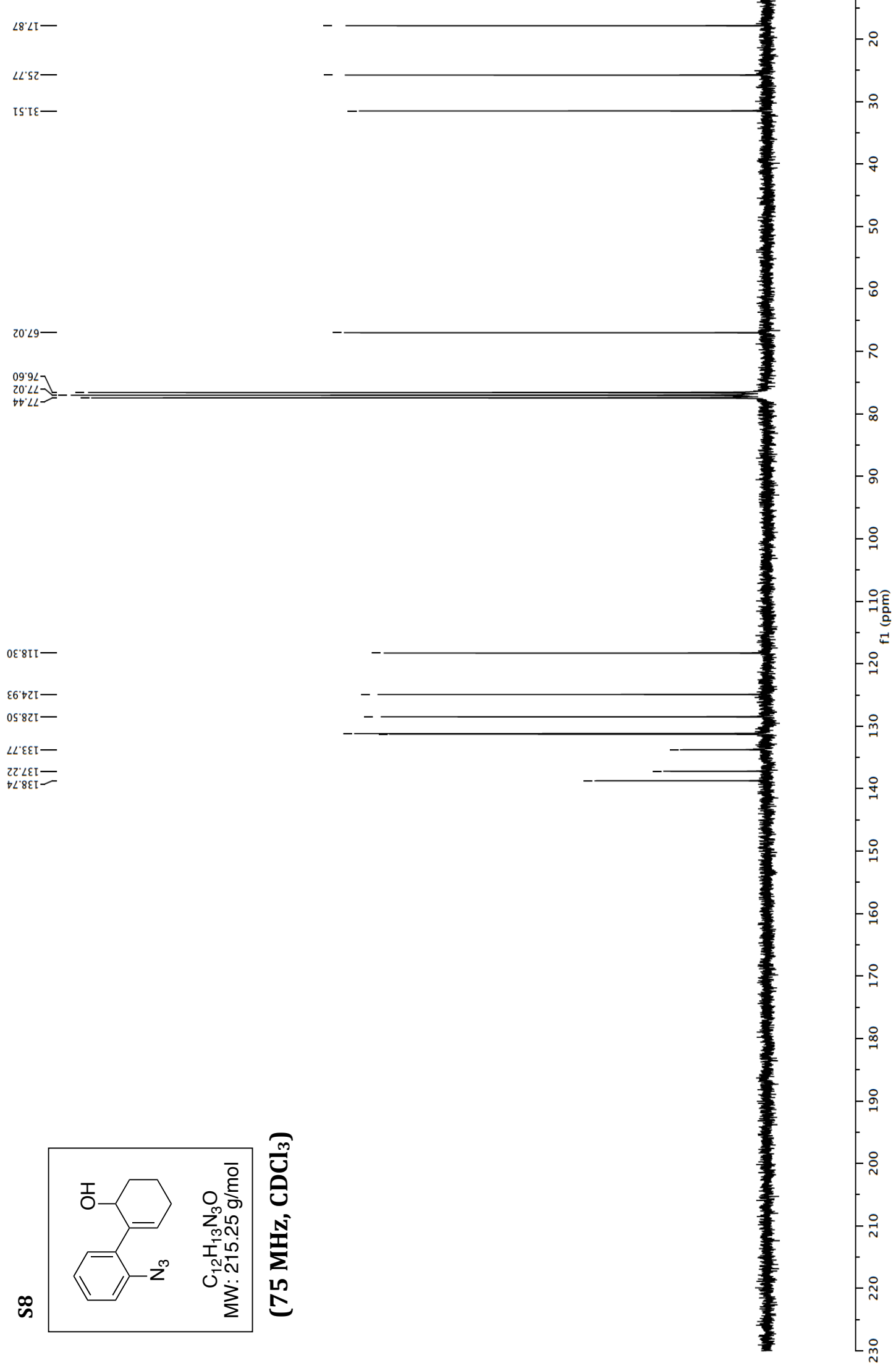

nิ 


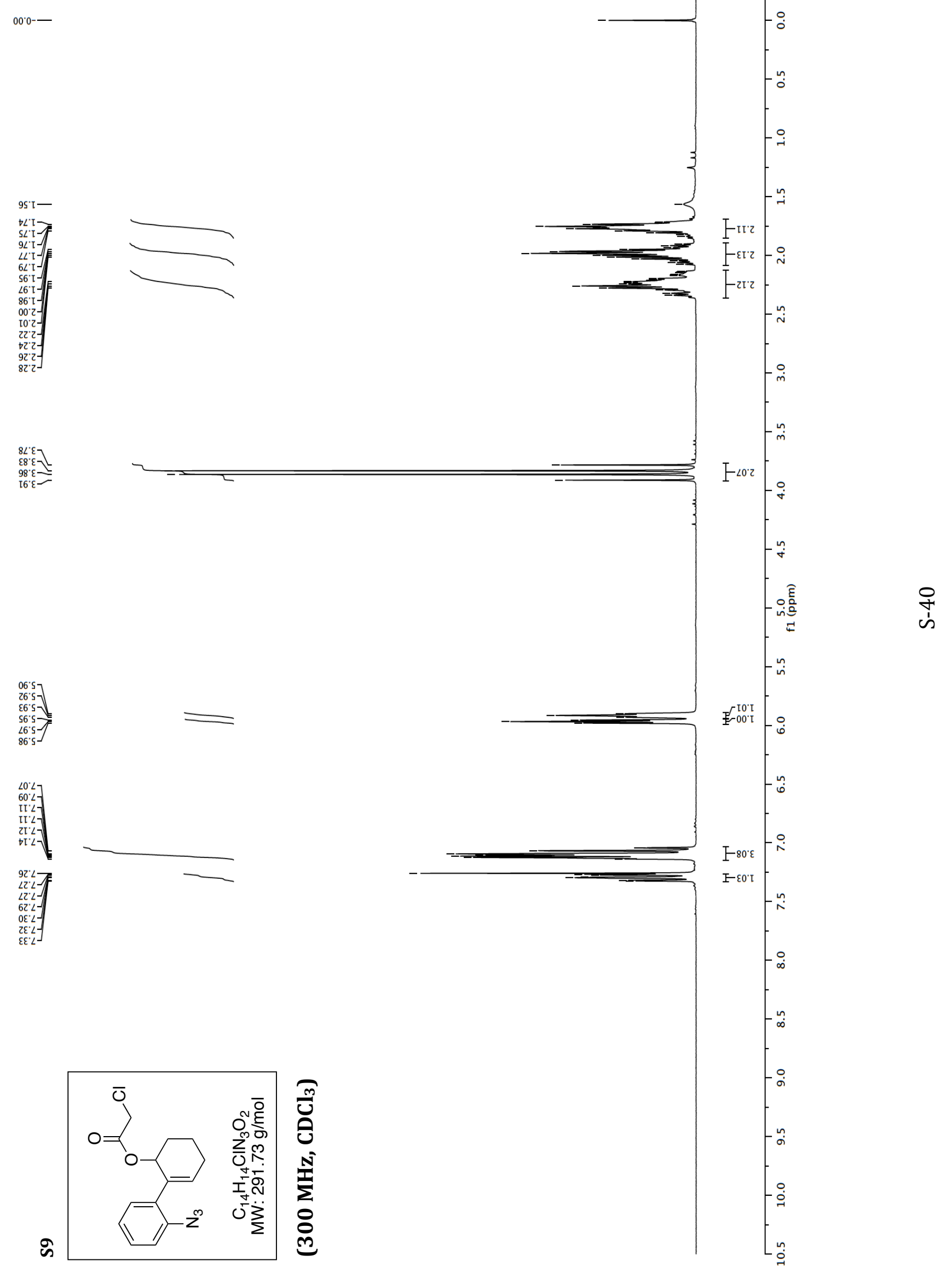




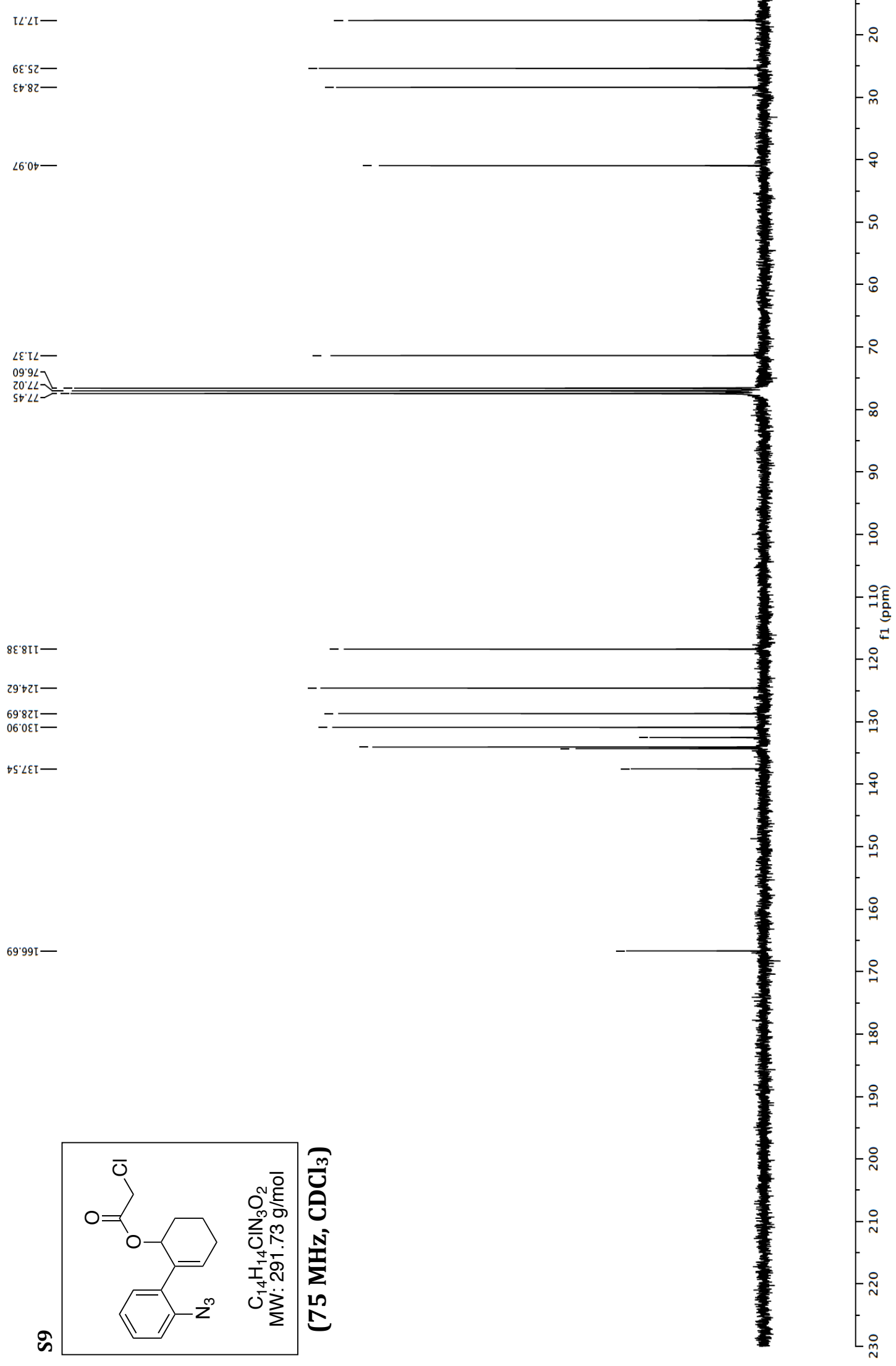



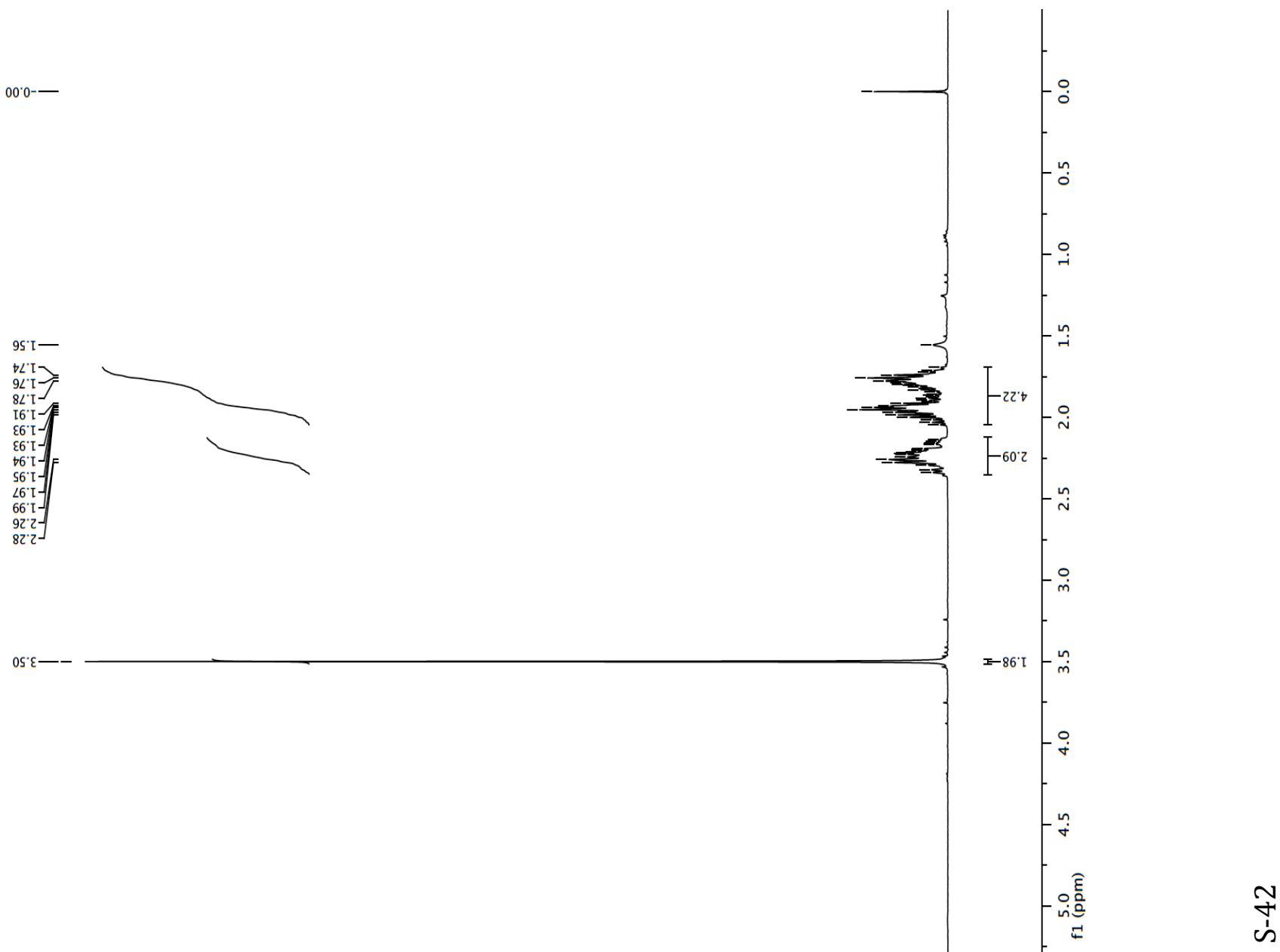

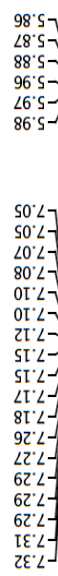
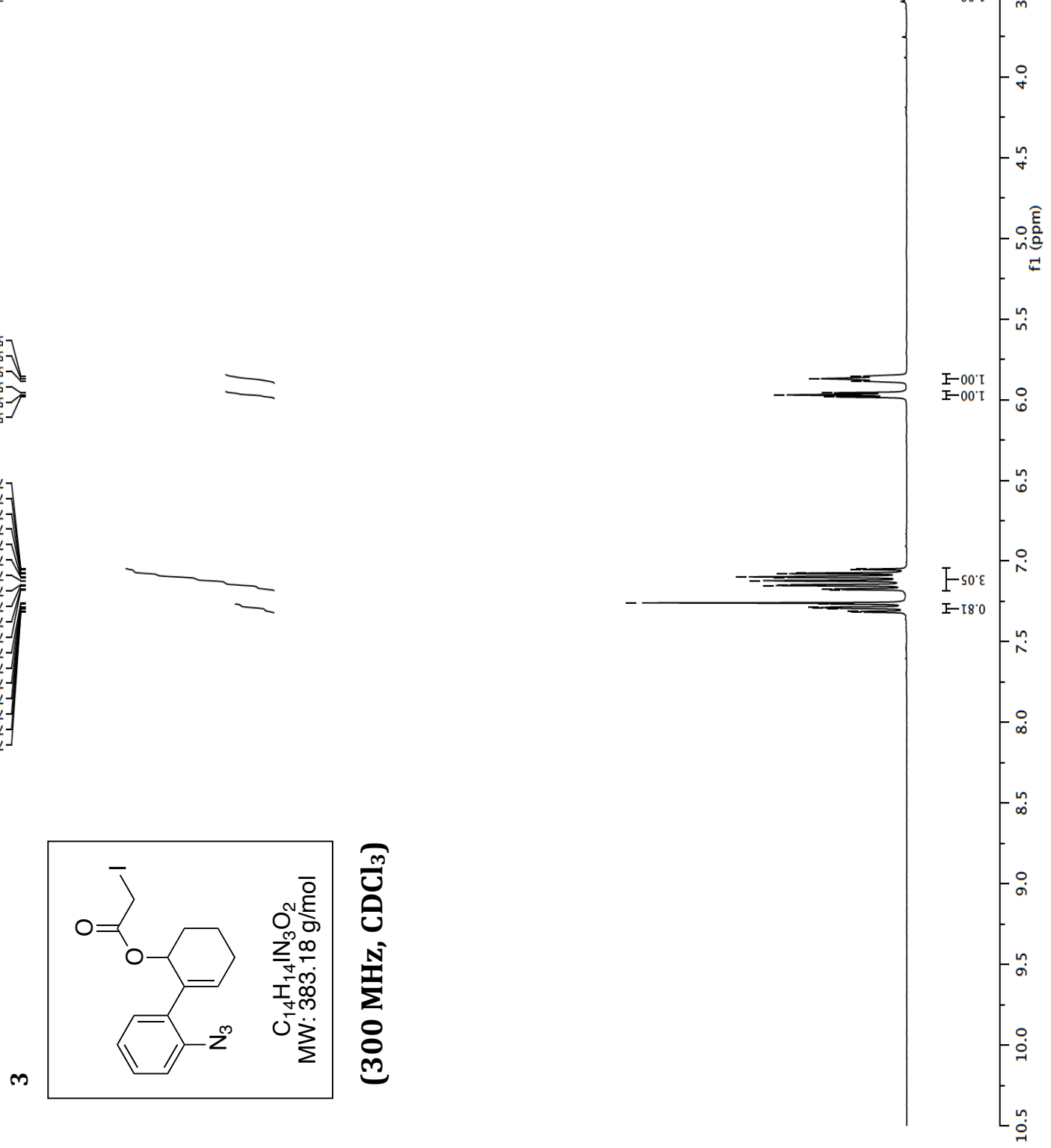


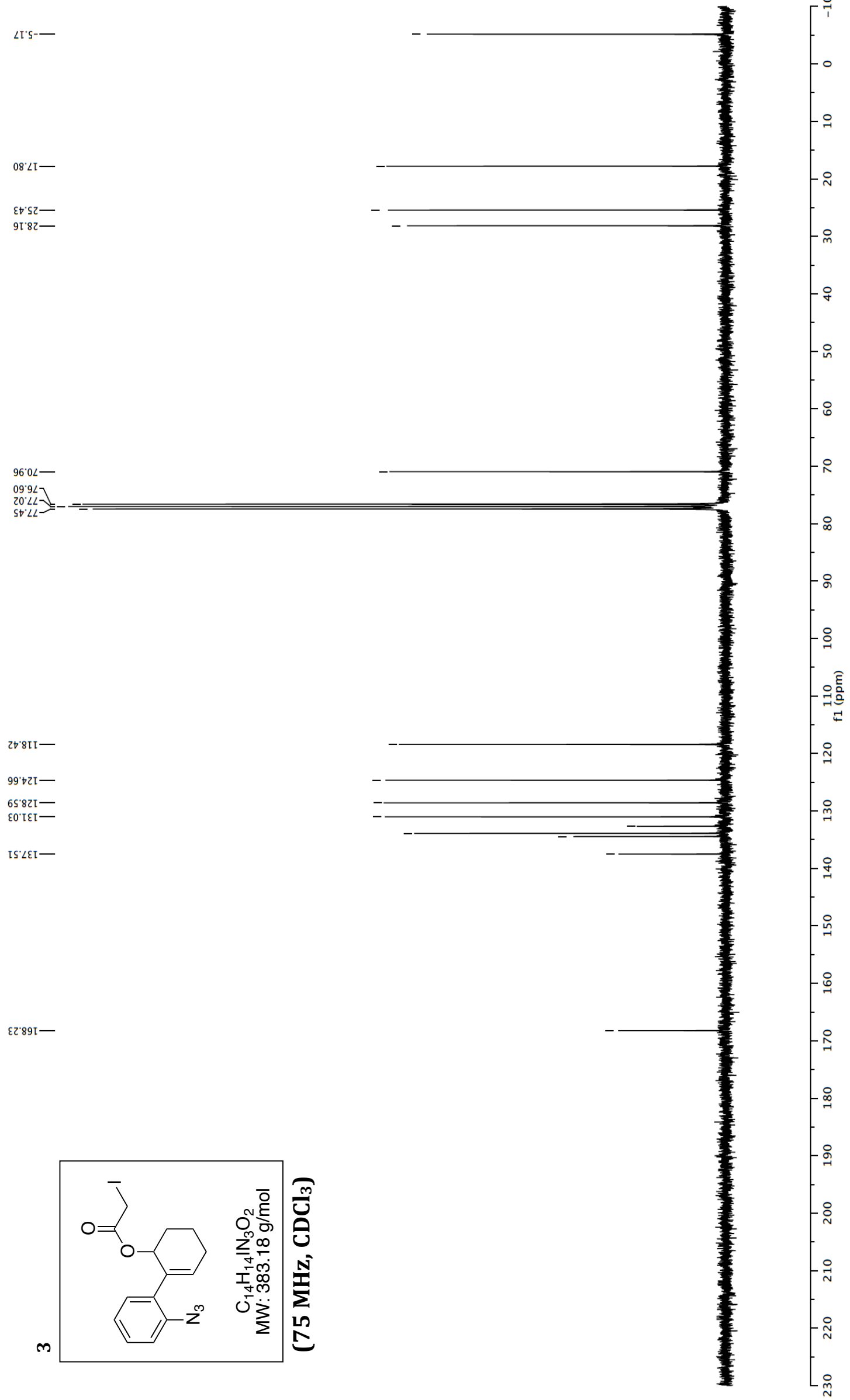




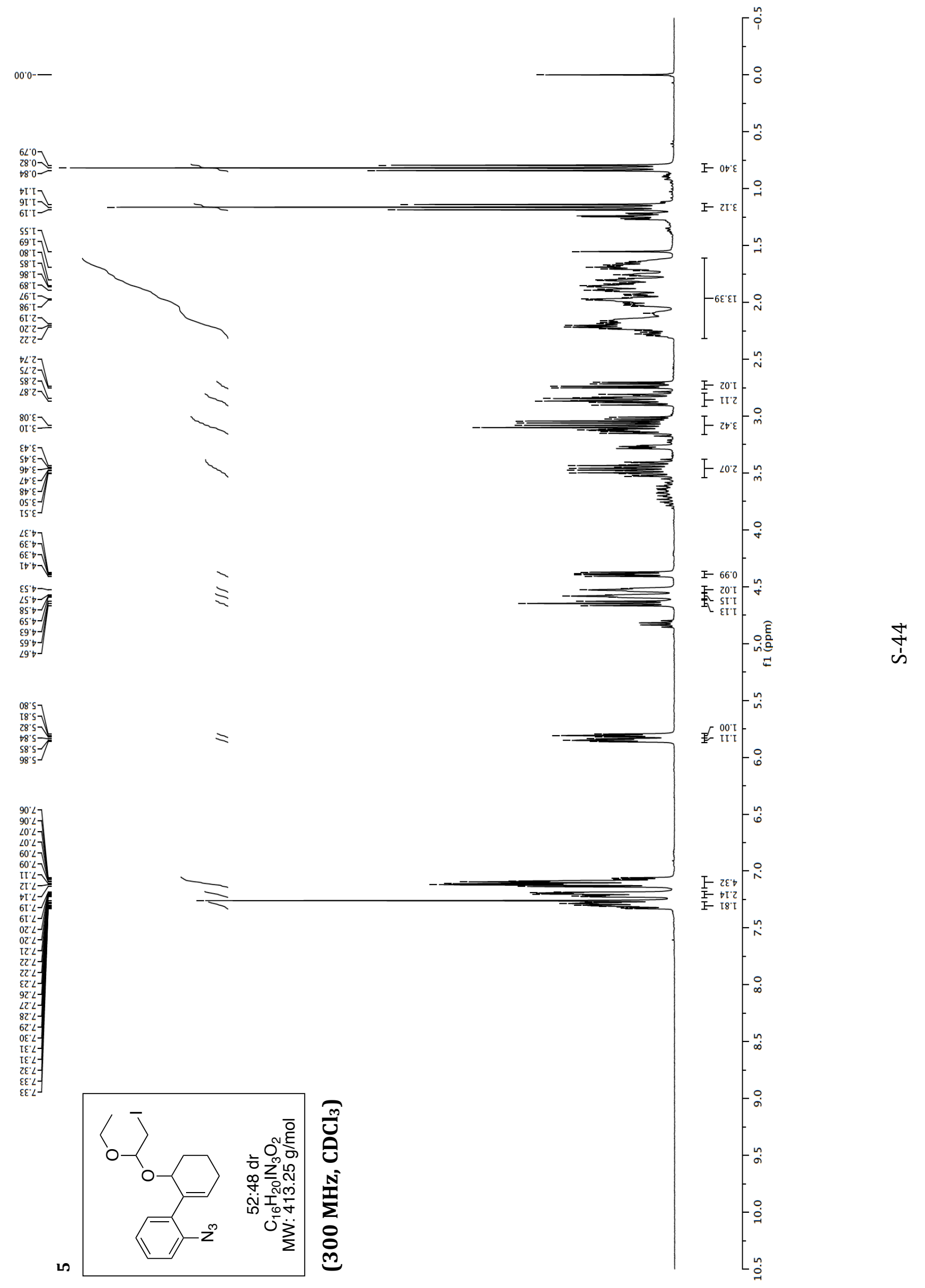




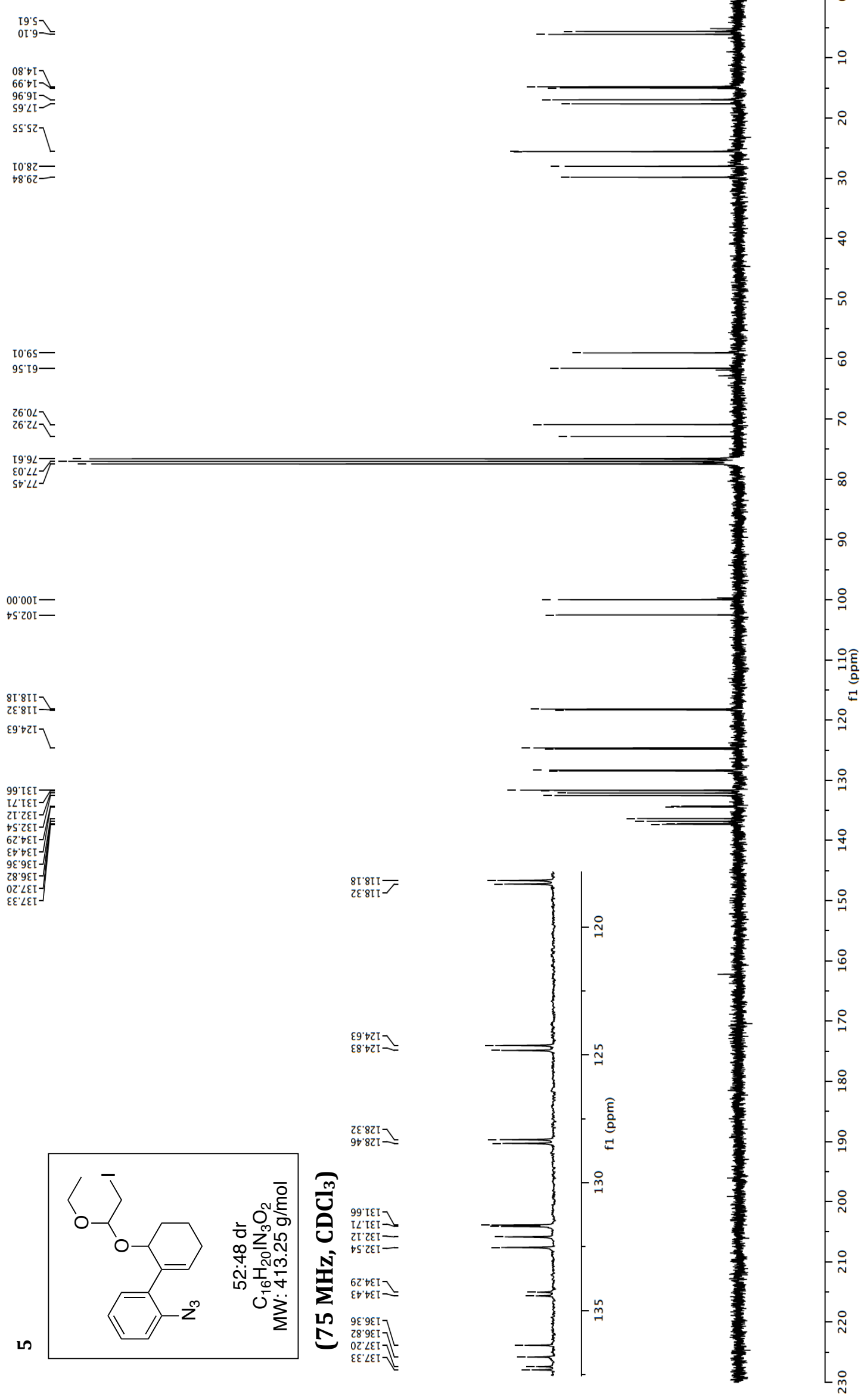




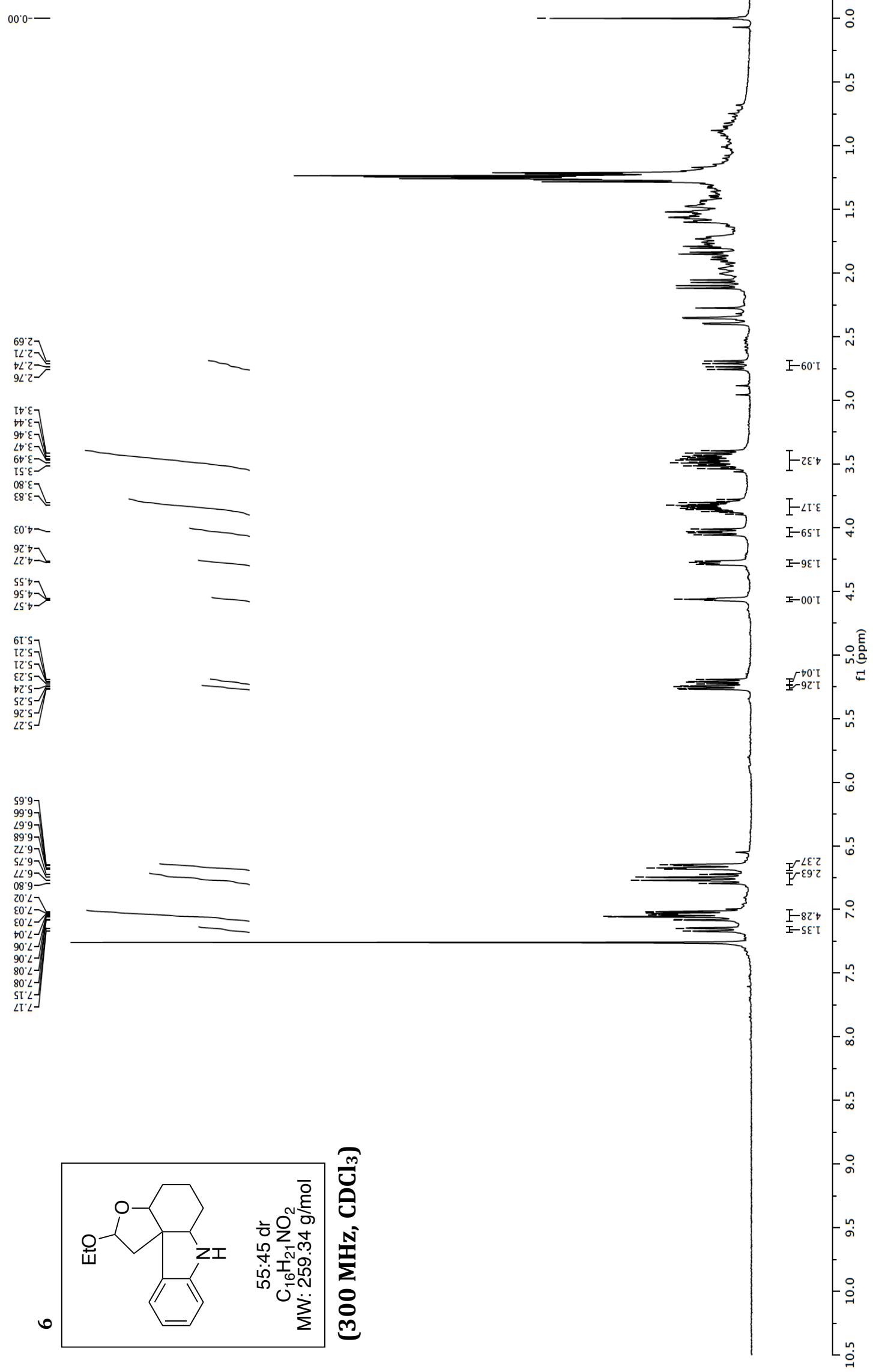




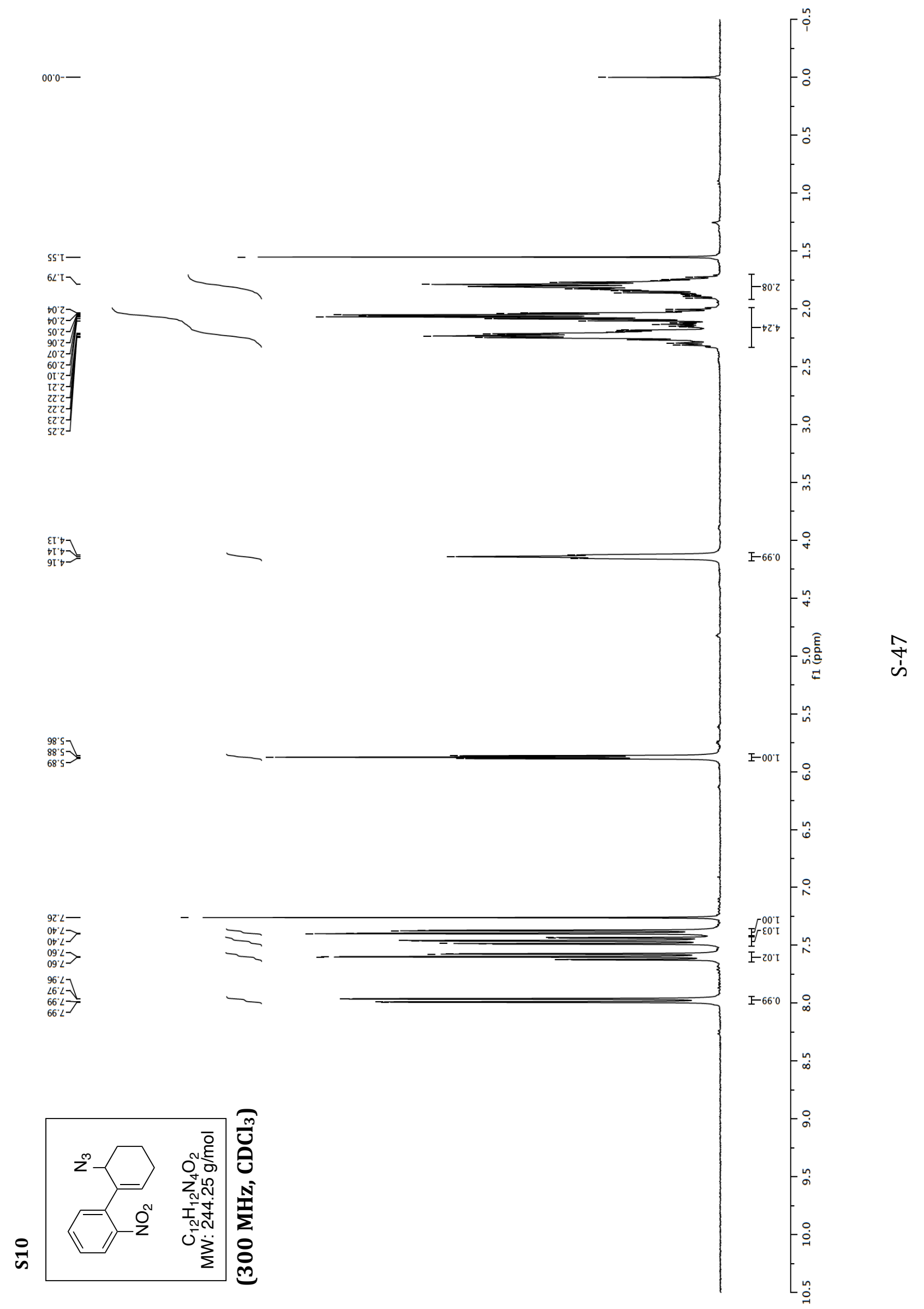




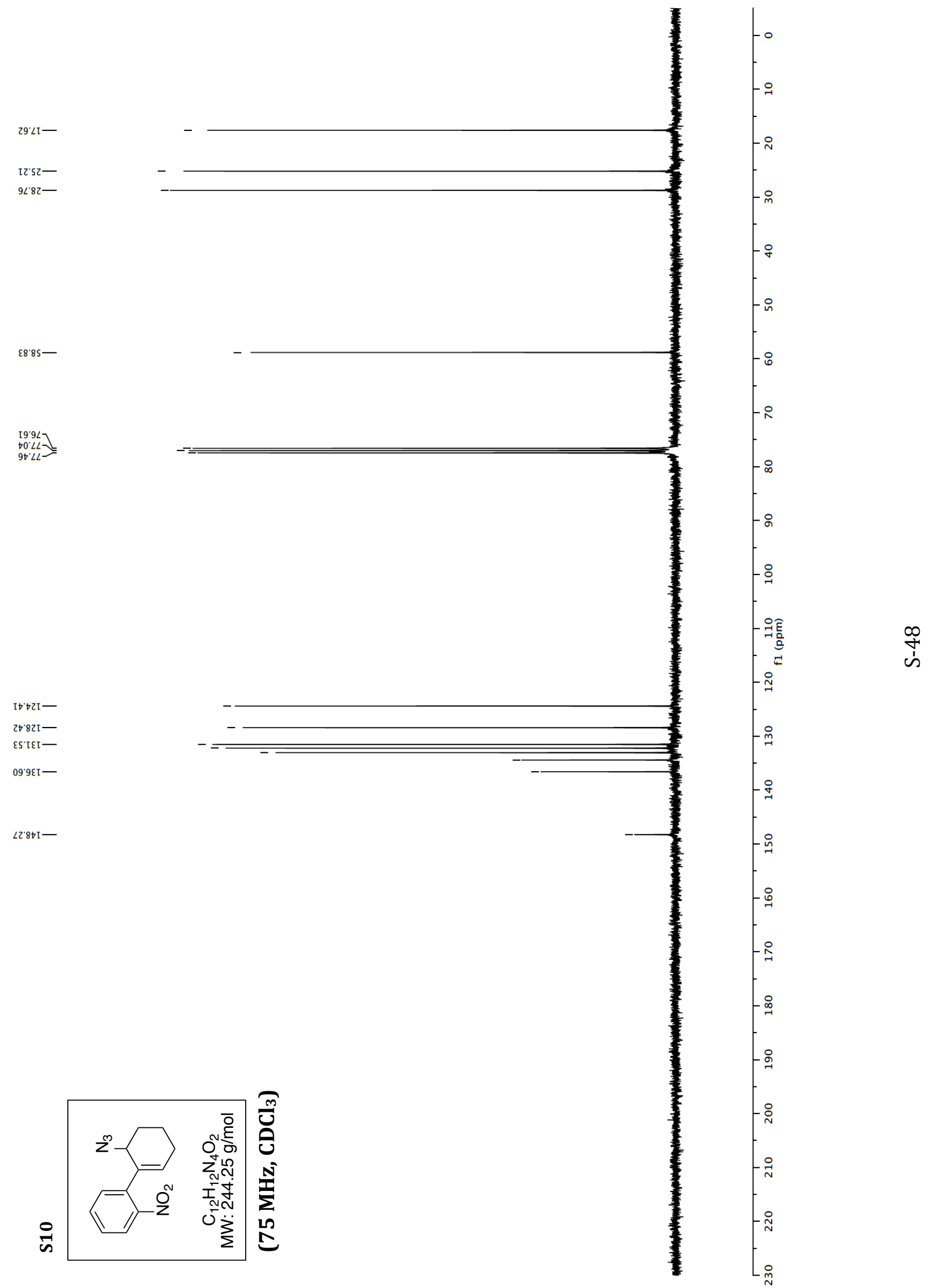



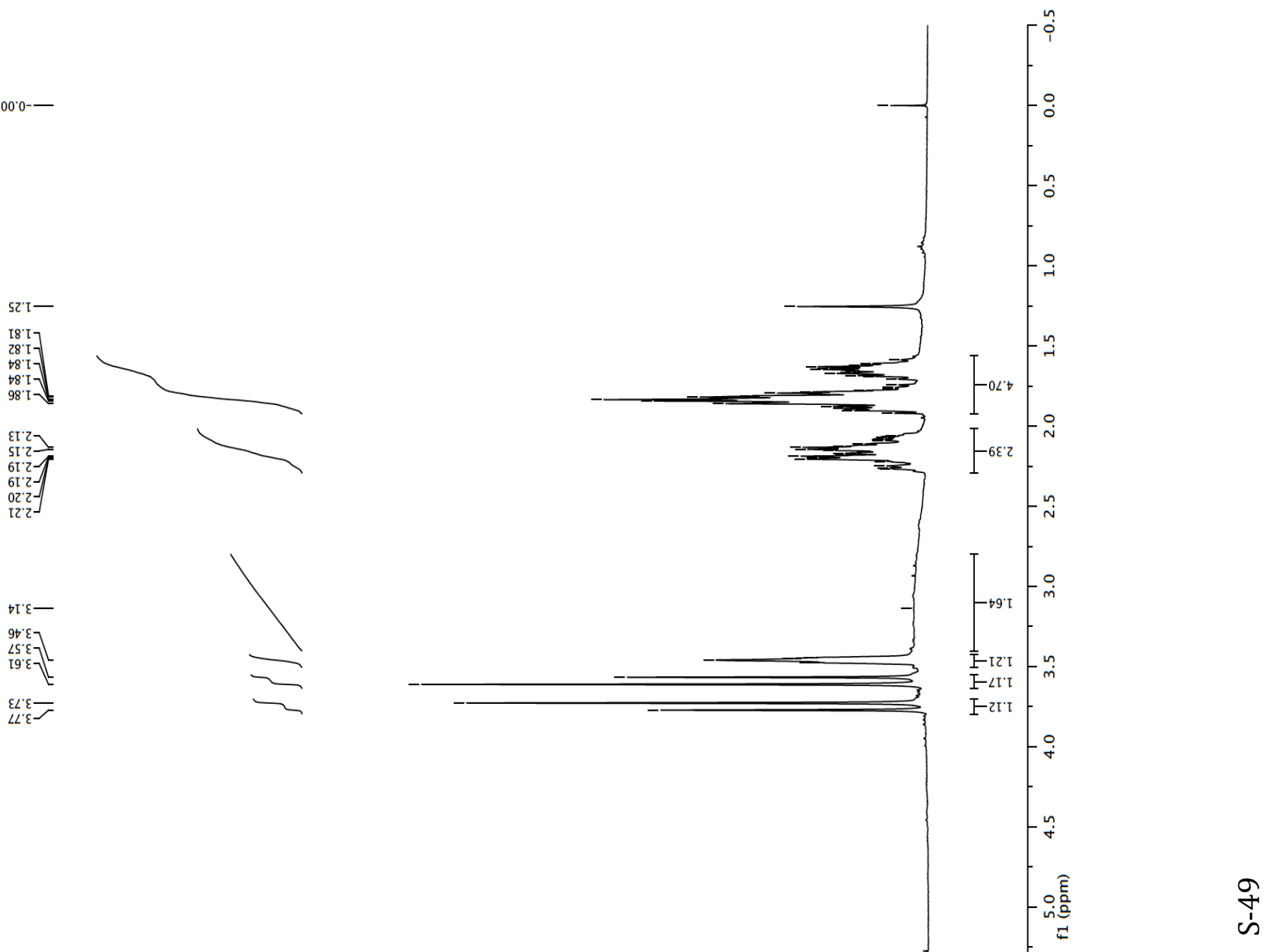

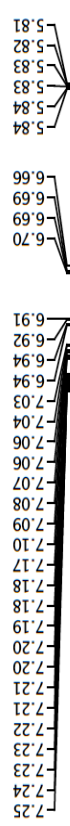

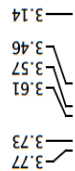

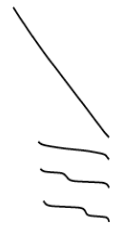

$\stackrel{9}{+}$

के 


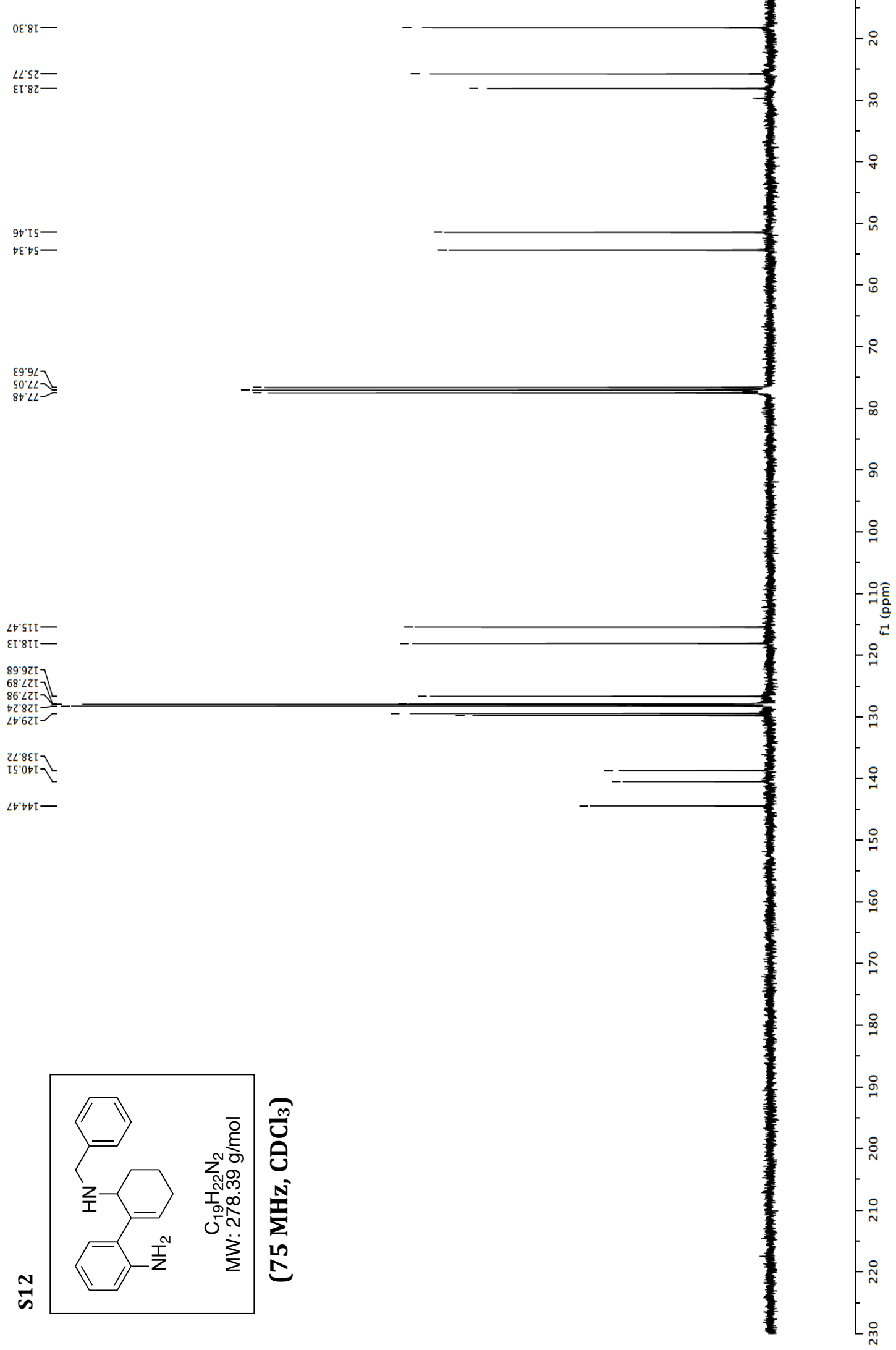




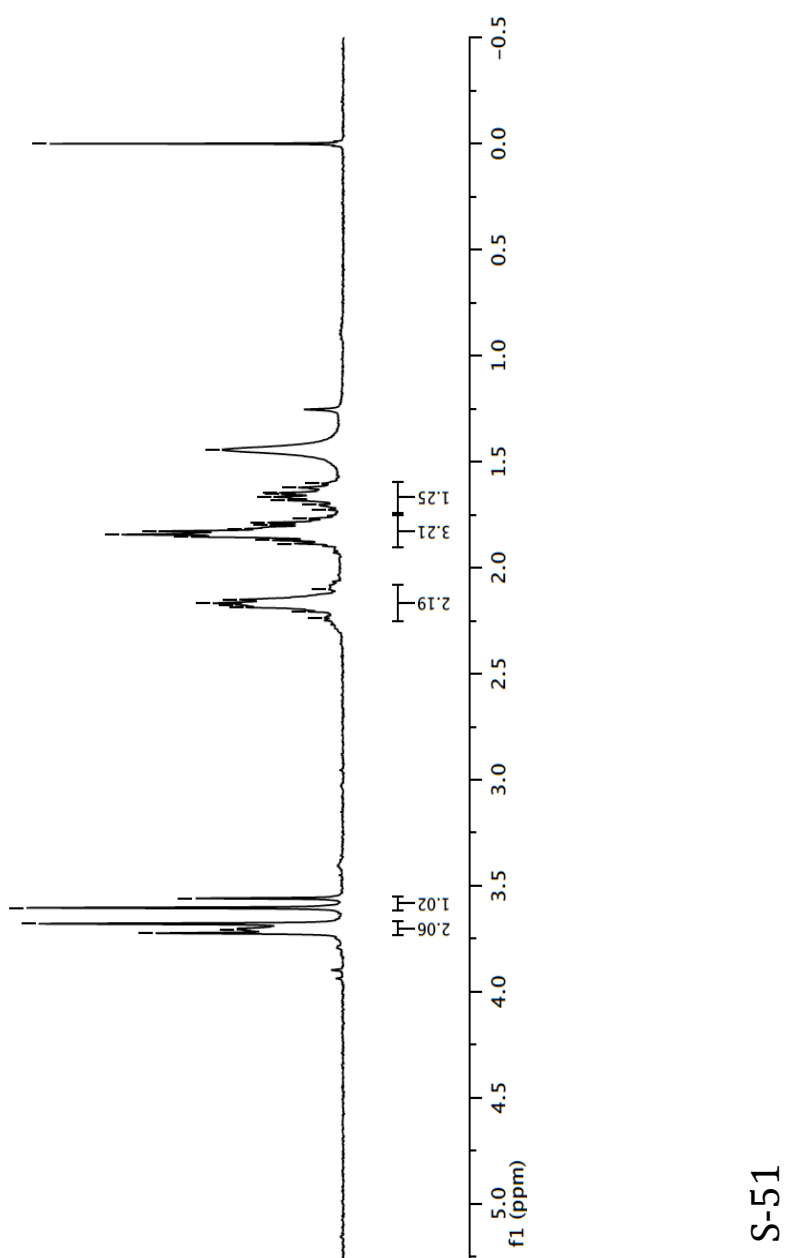

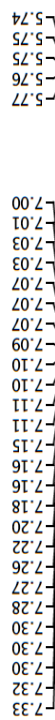

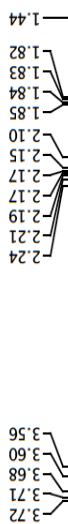

工

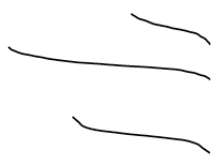

เุ

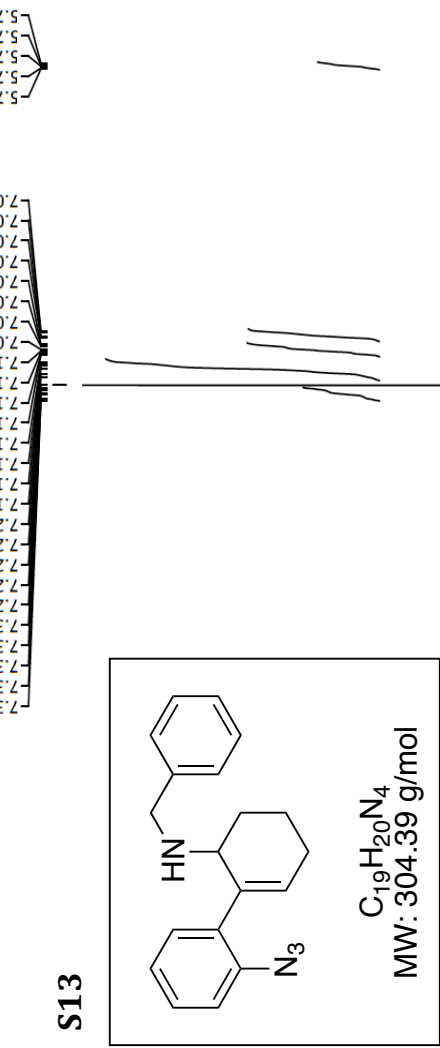

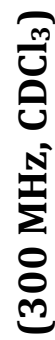

$m$
0
0
0
0
0
0
0 


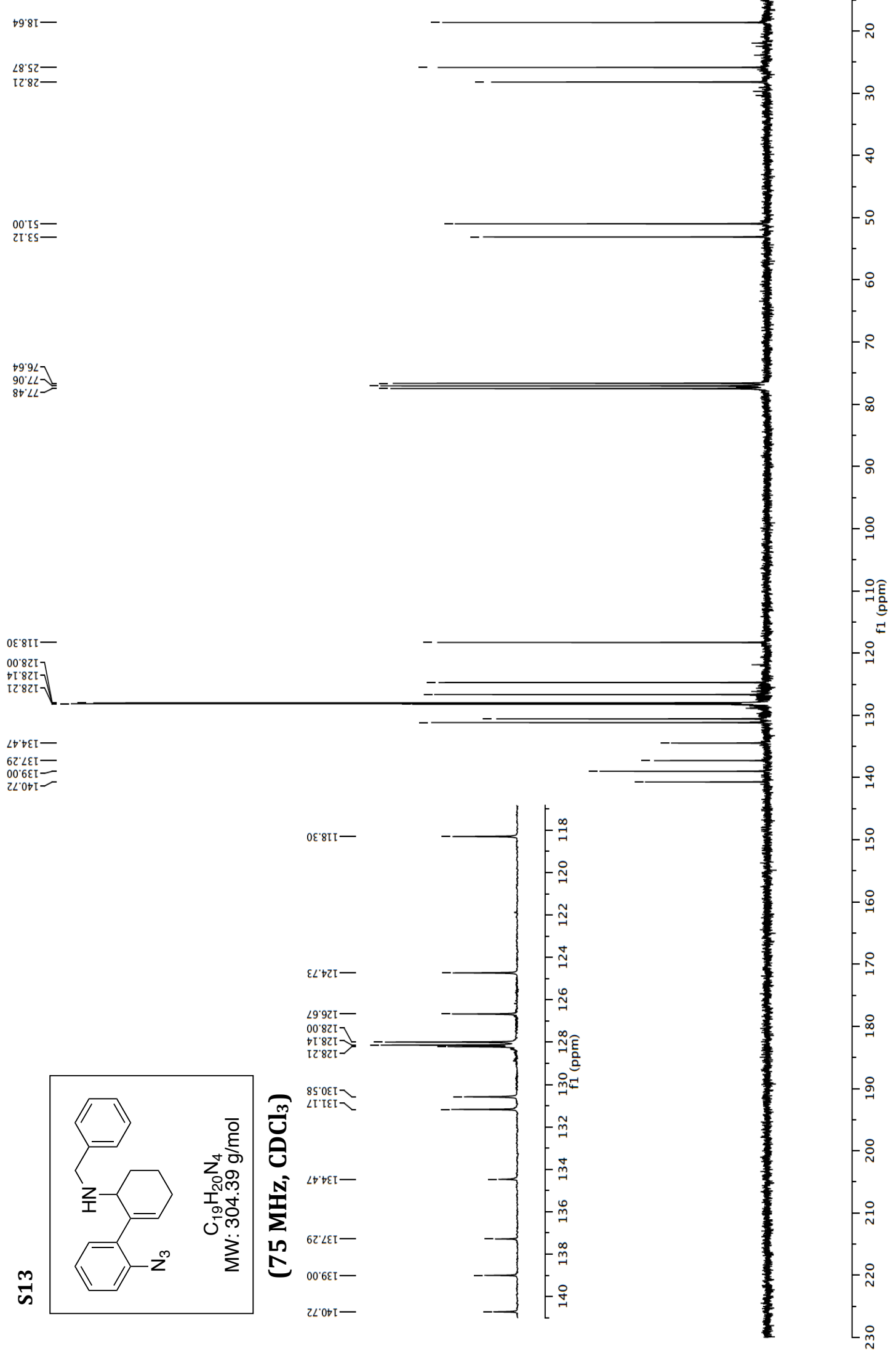



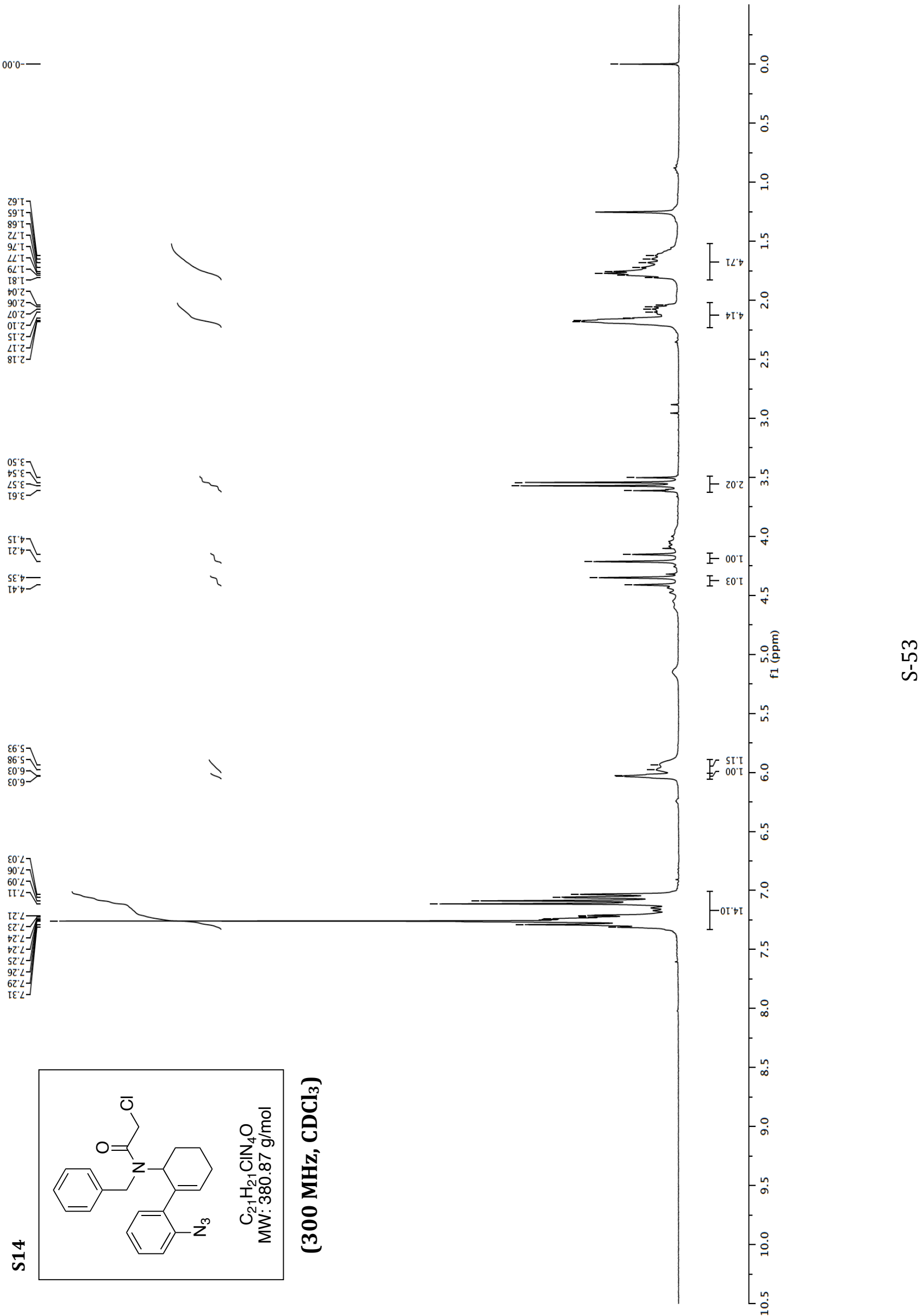


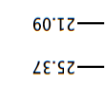

SI 82 -

$\angle S \cdot T t-$

$t 6: \angle t-$

$\angle I ' t S-$

6S.8II-

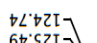

$98.82[$ ]

๕๕'ح६ז-

,

s.tut

996

95
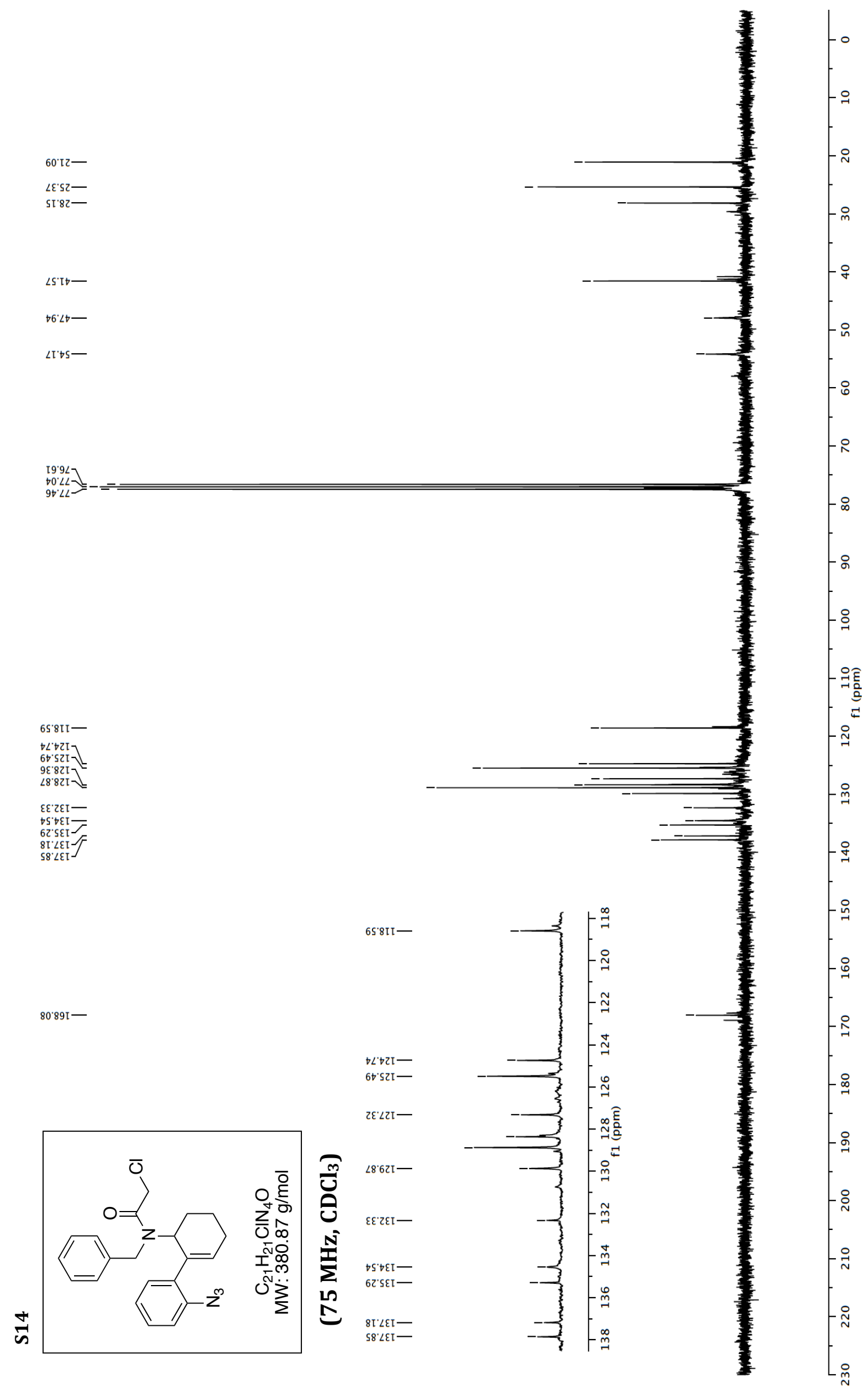

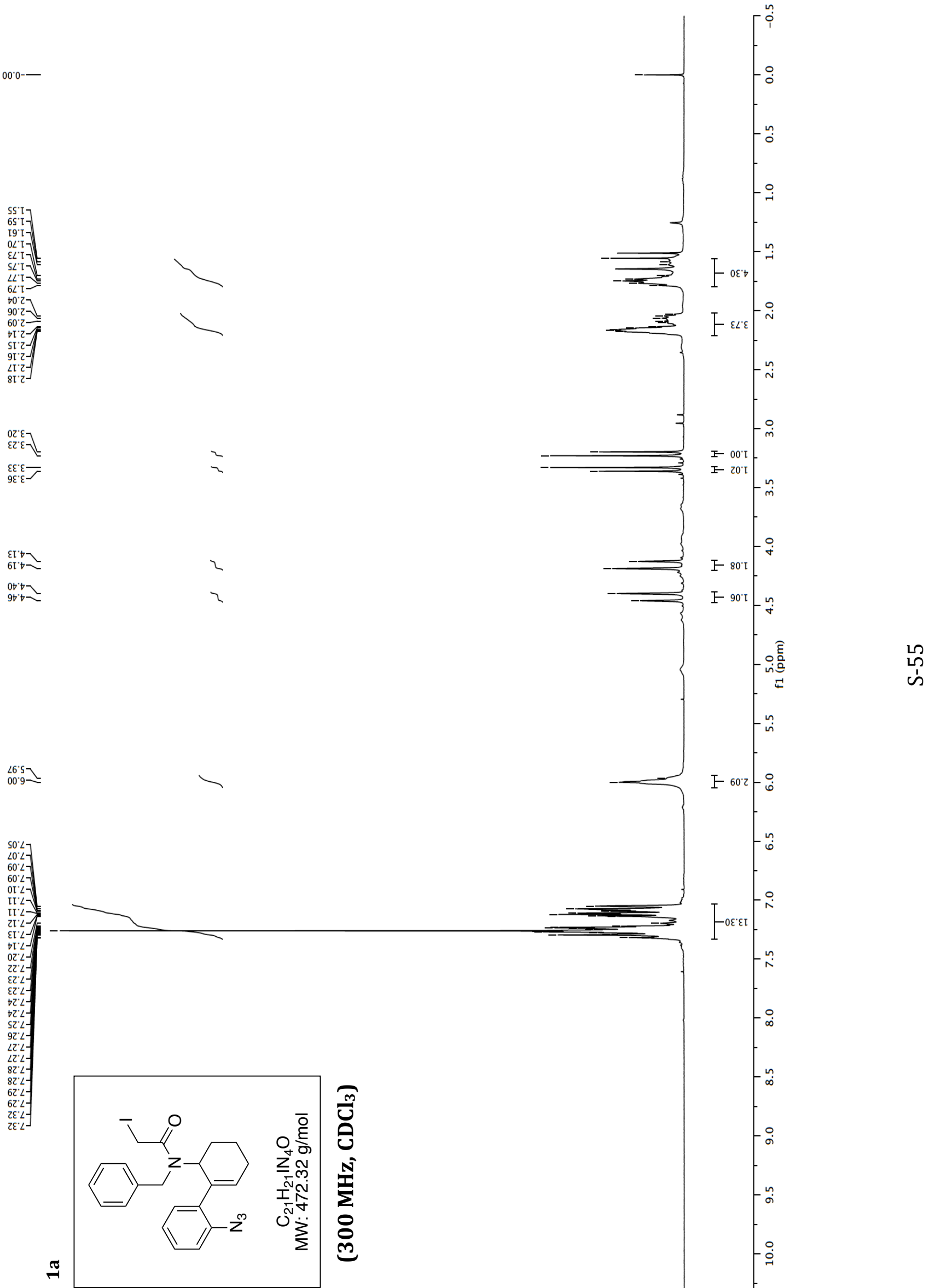

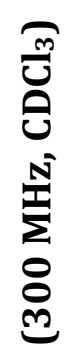




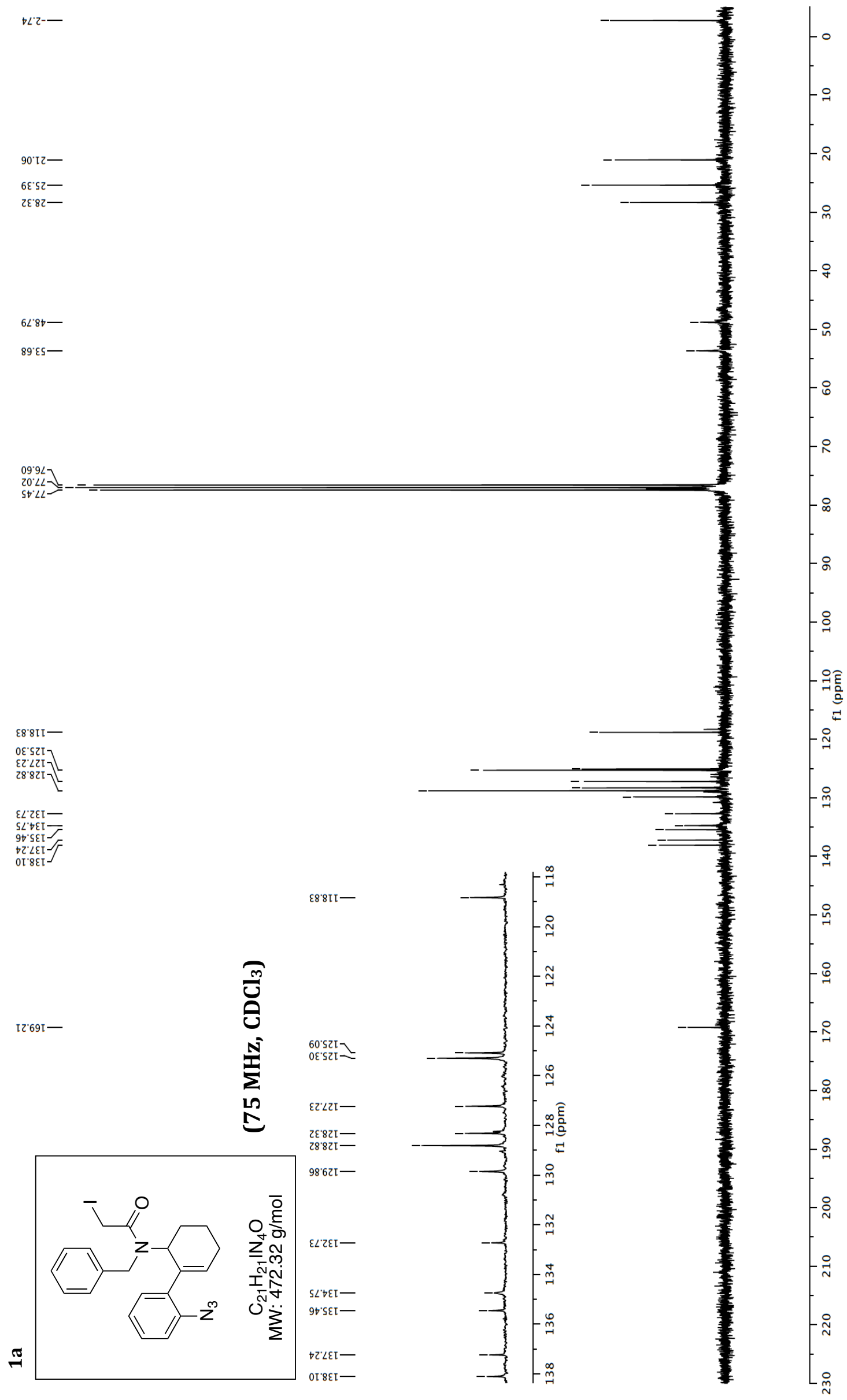




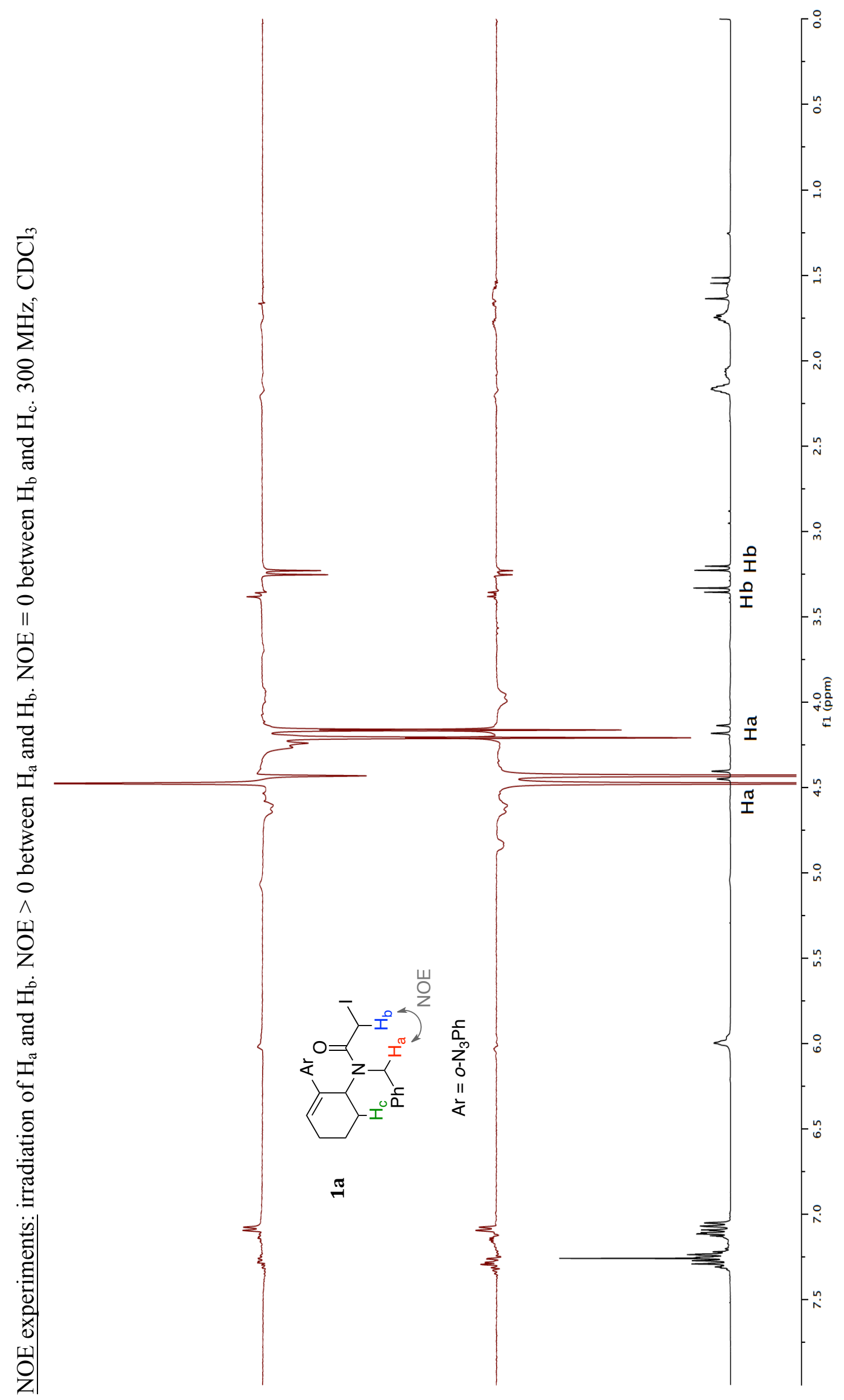

呙 


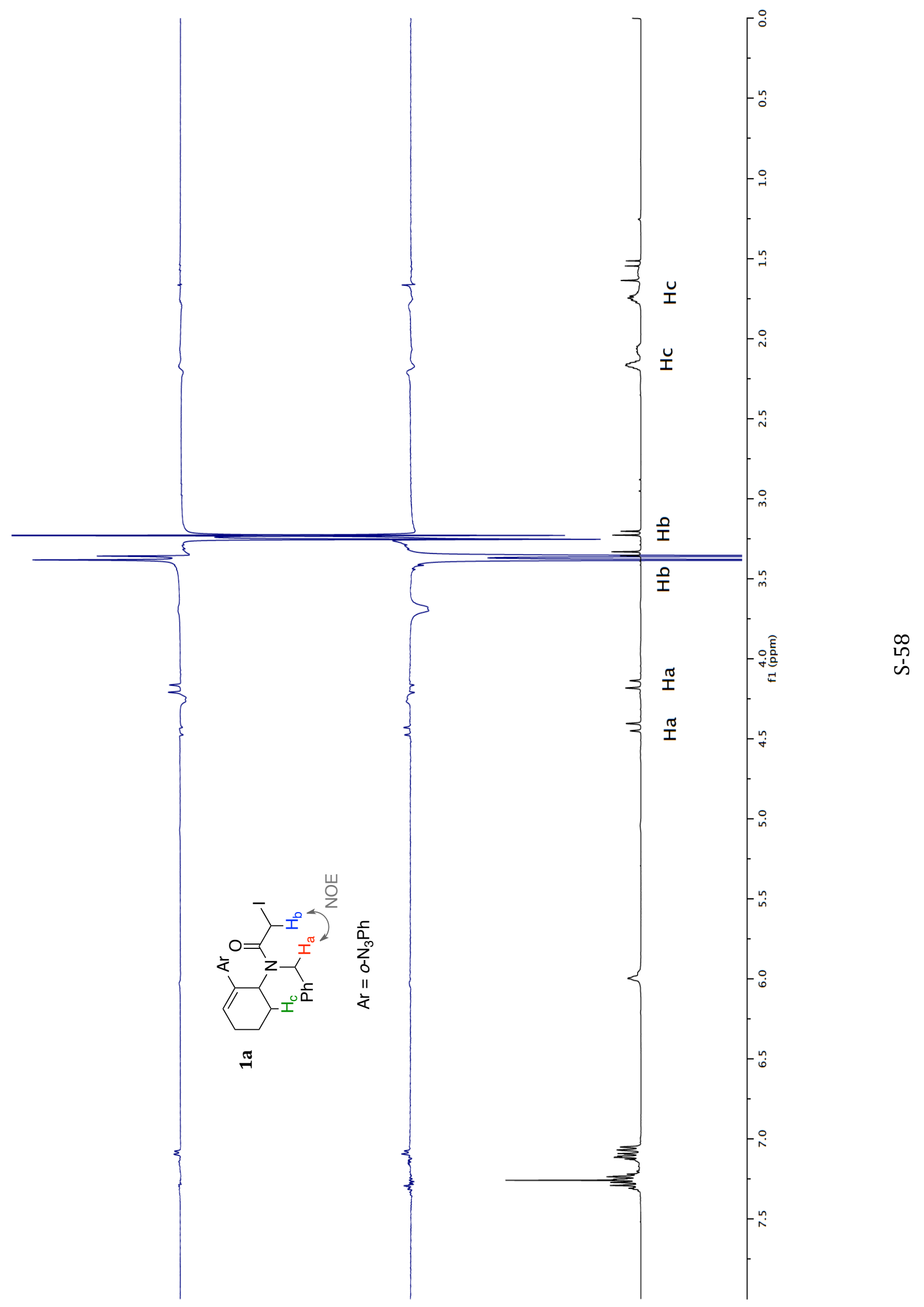




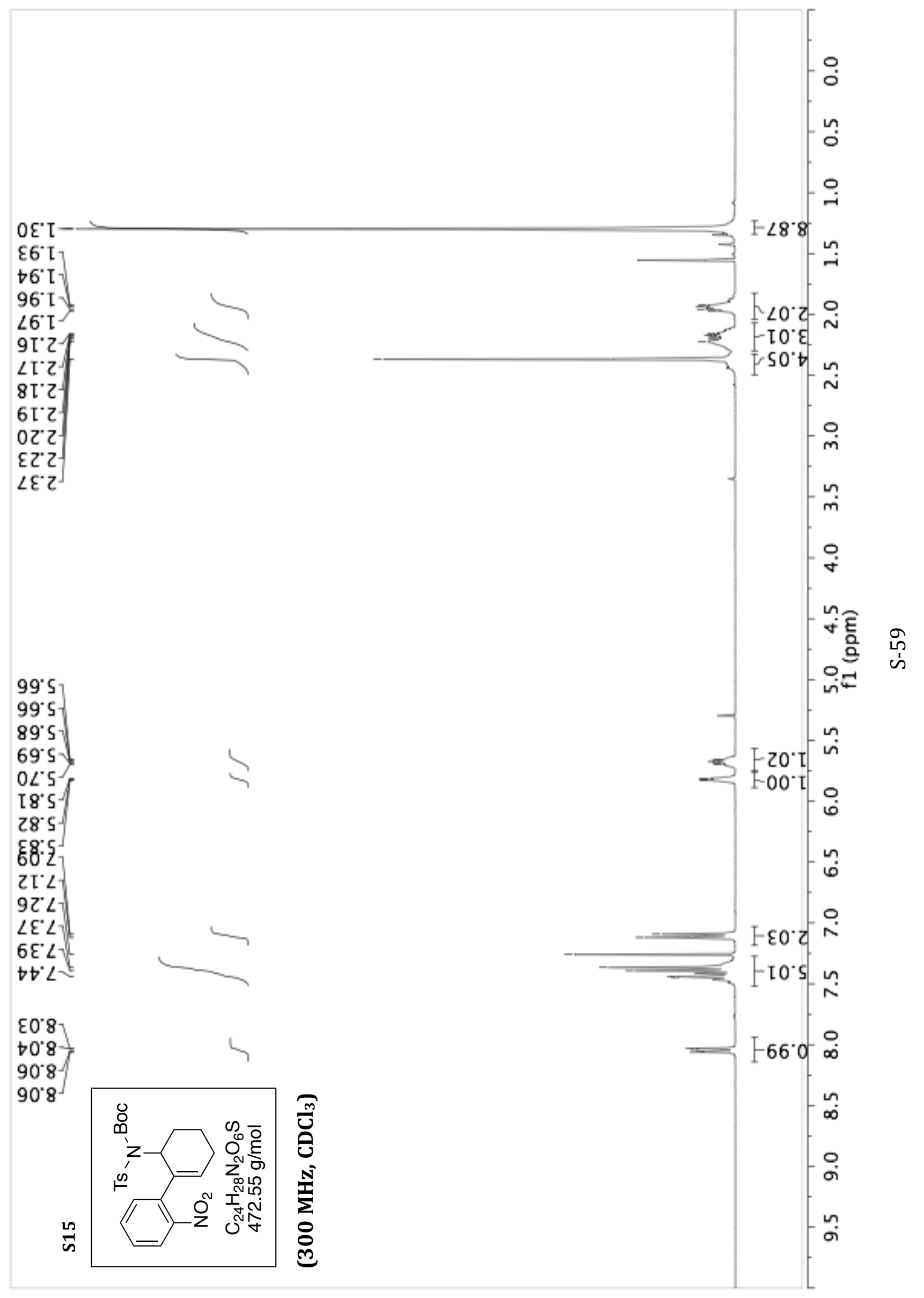




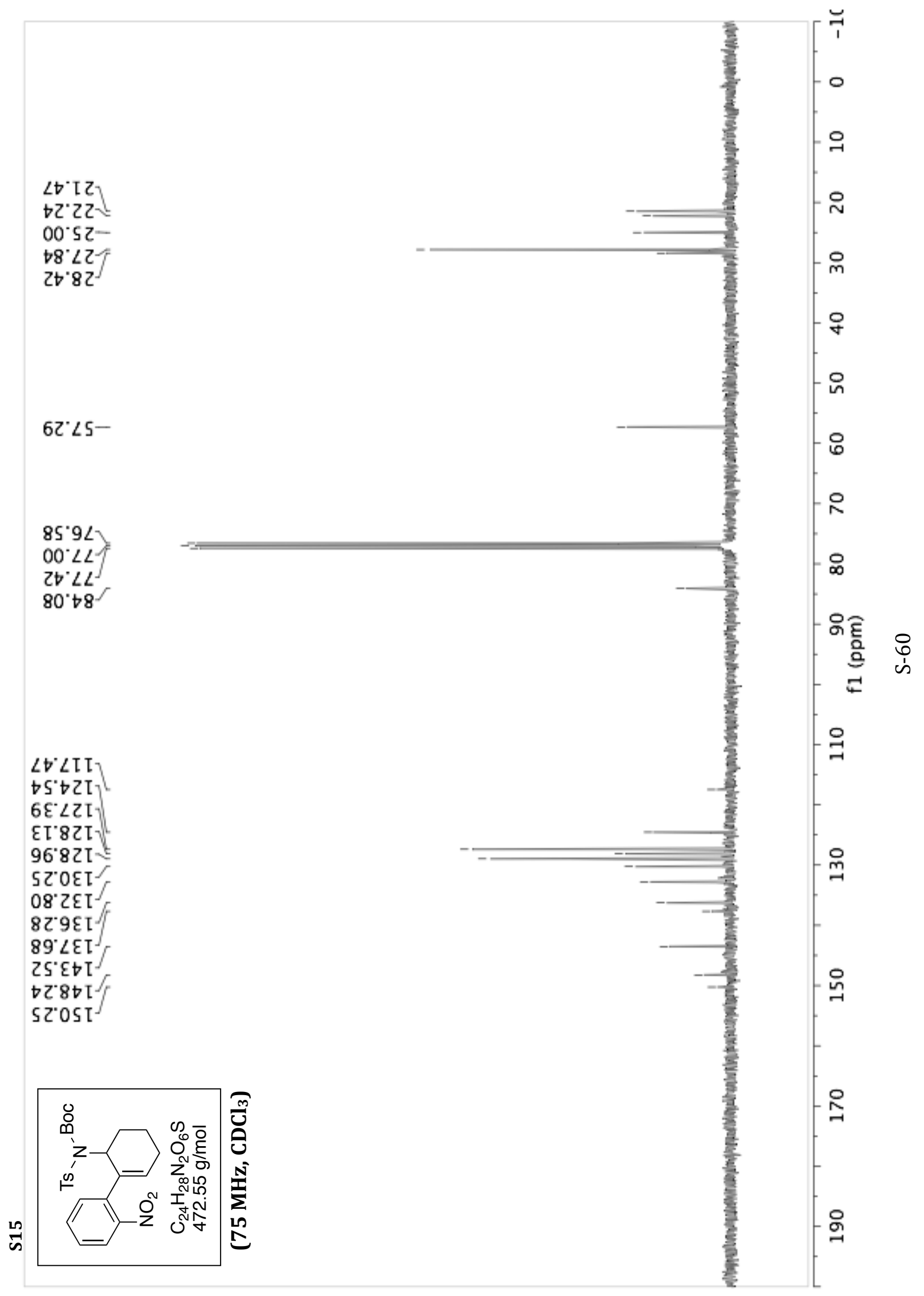




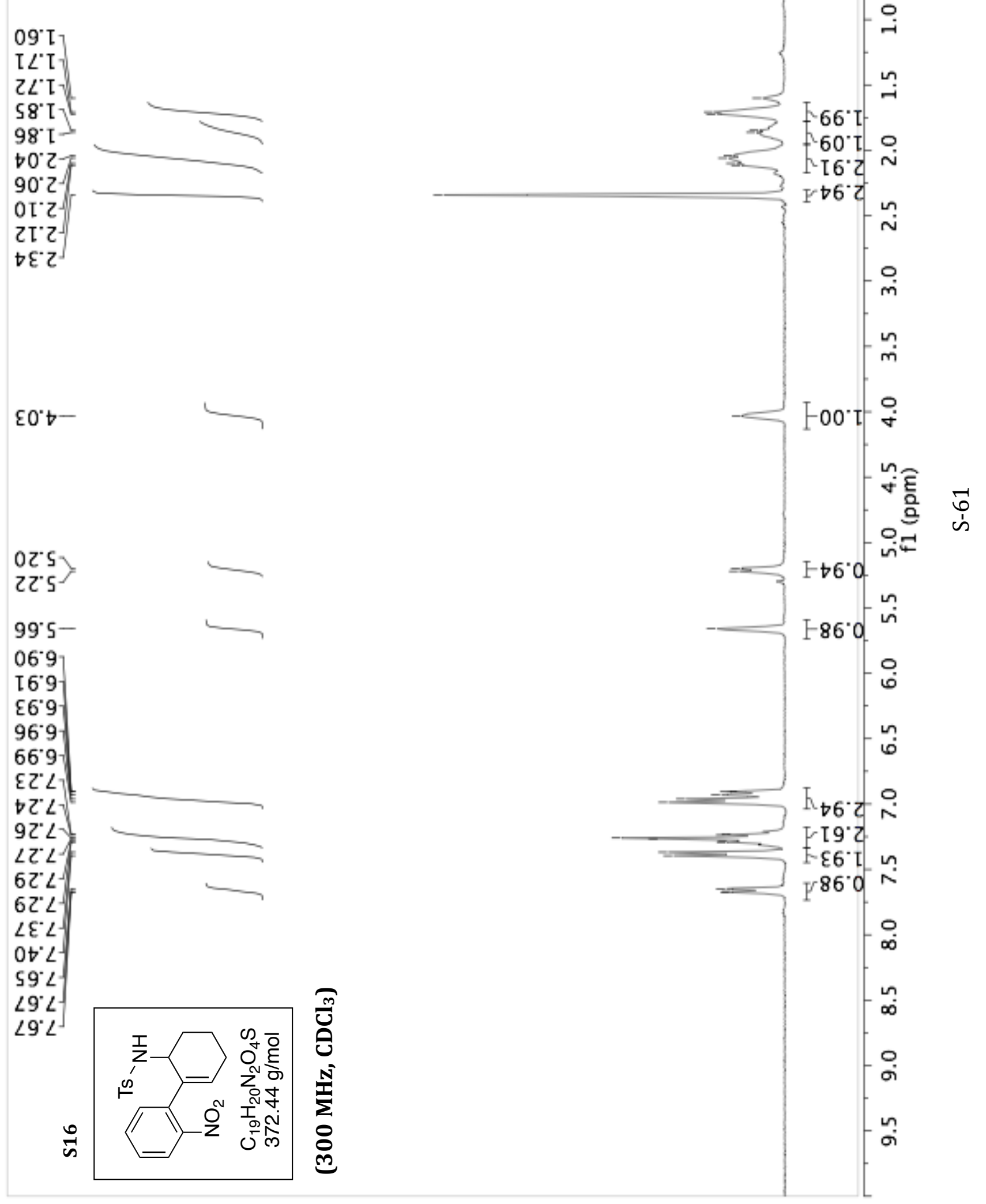




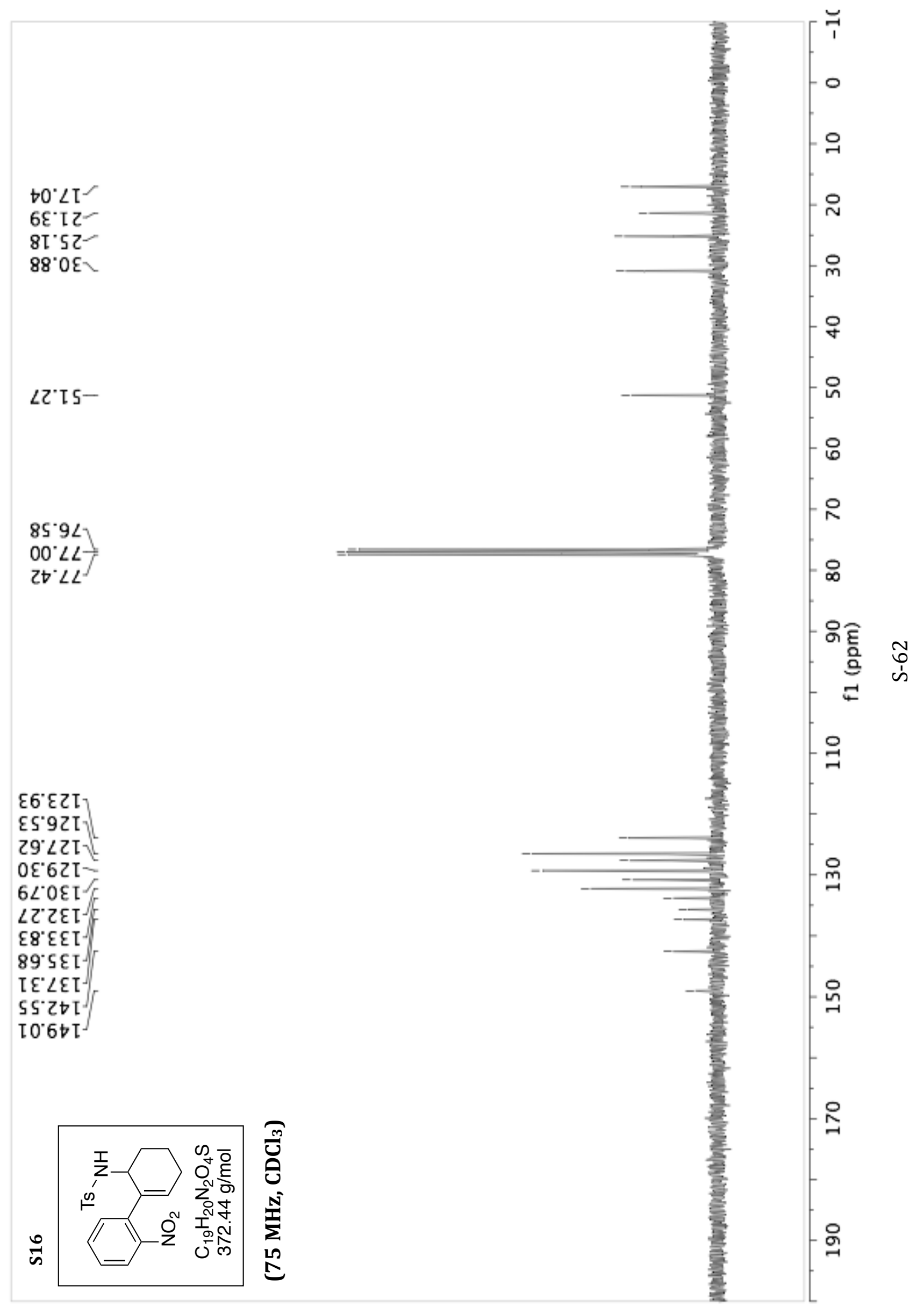




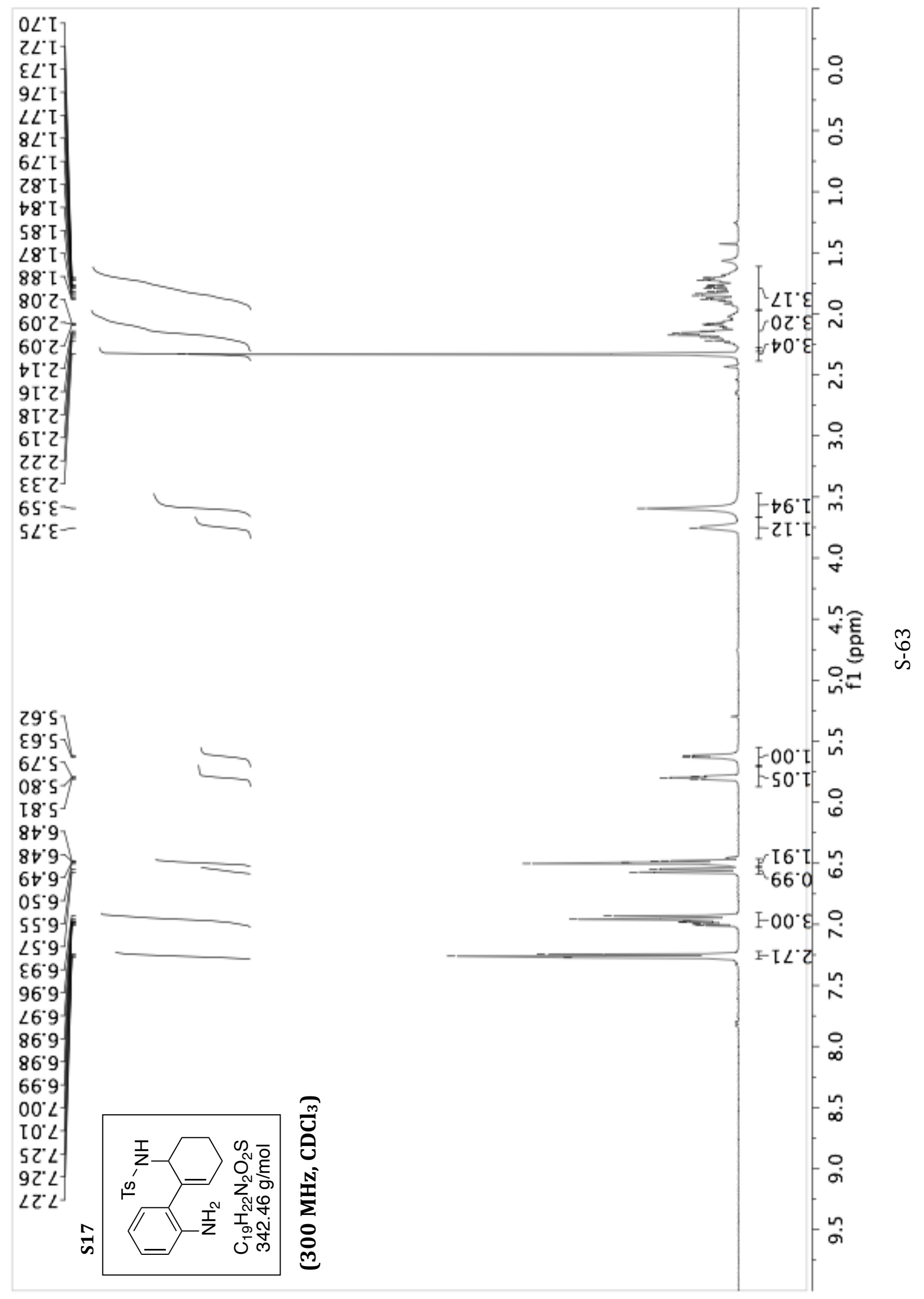




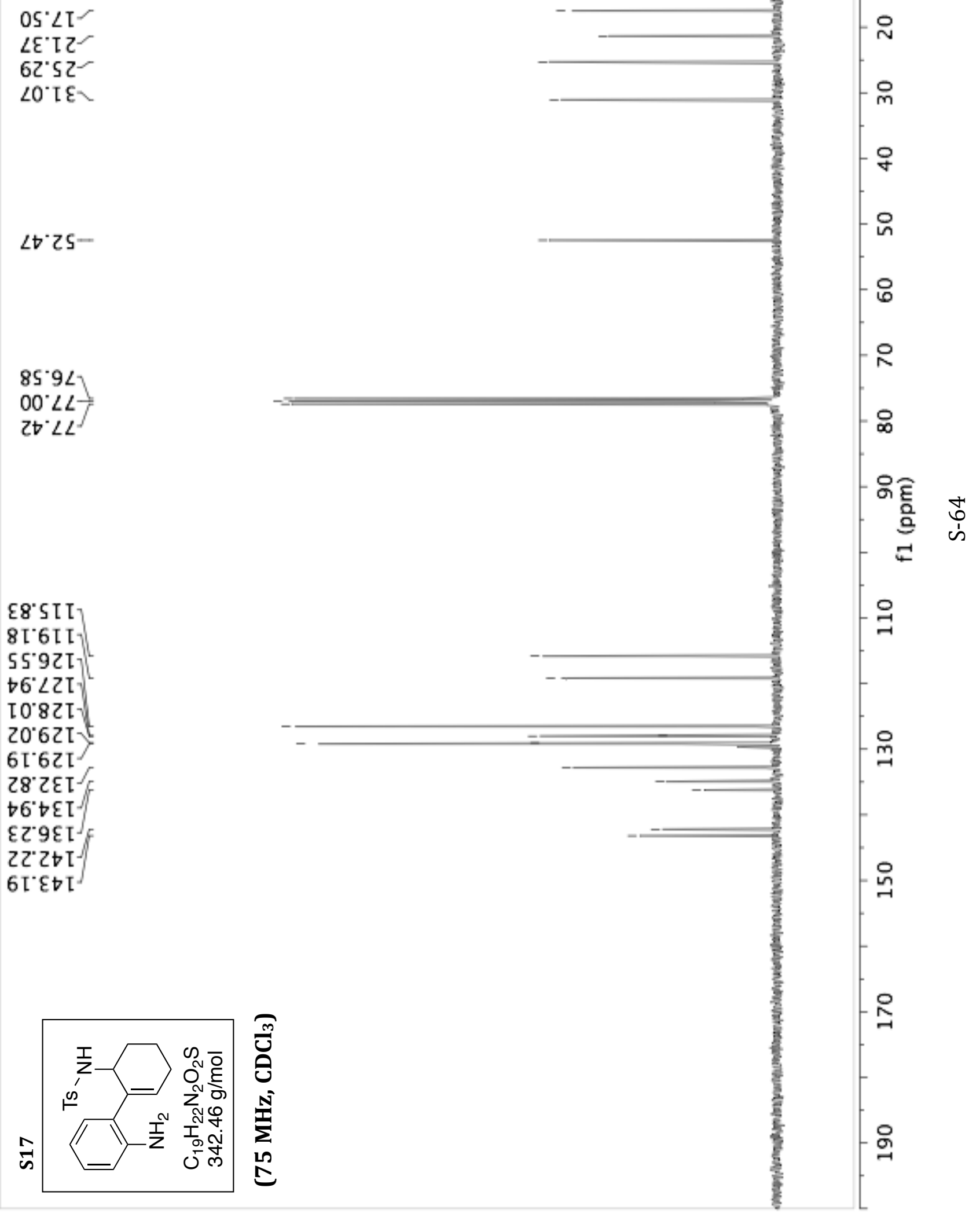




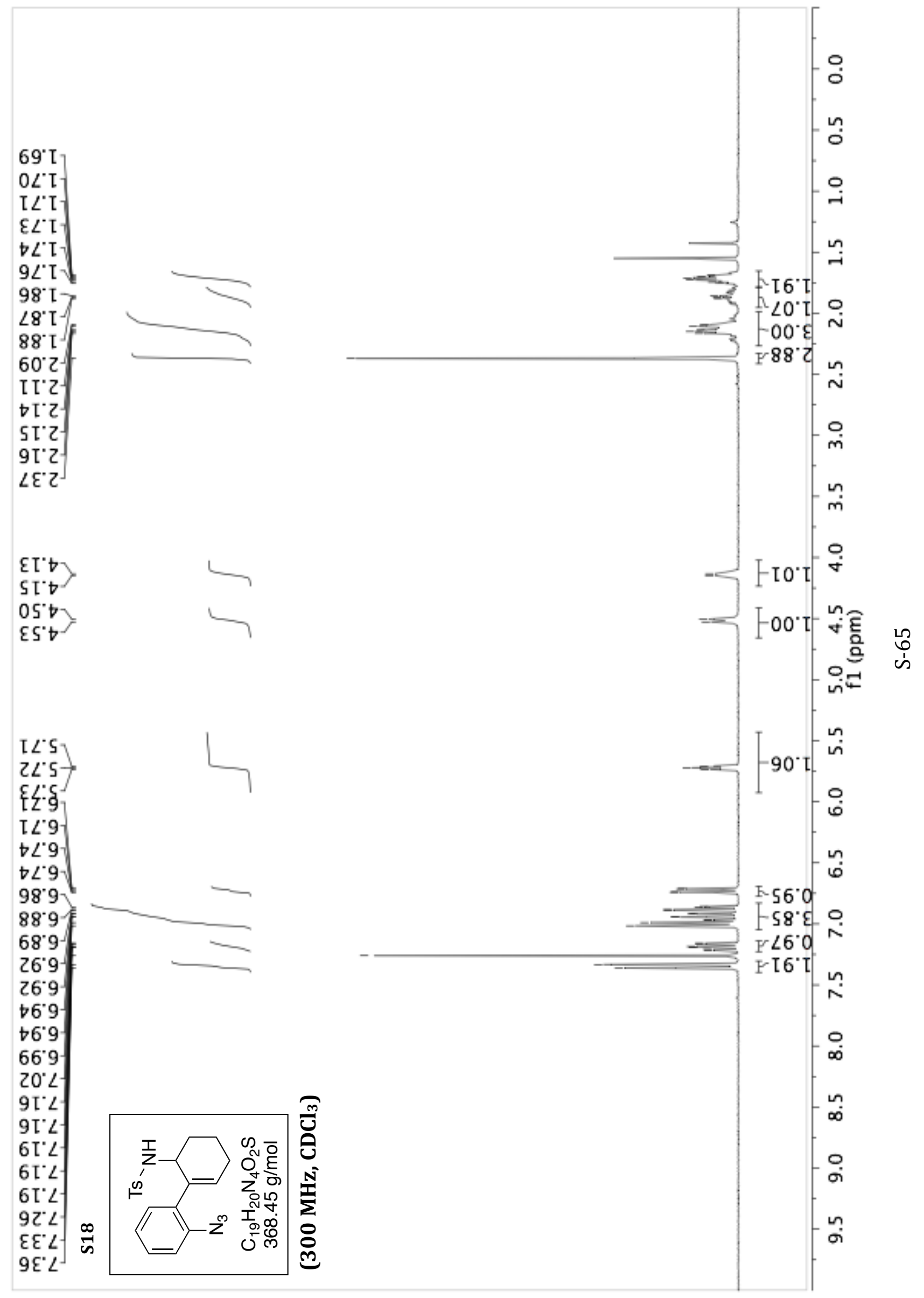




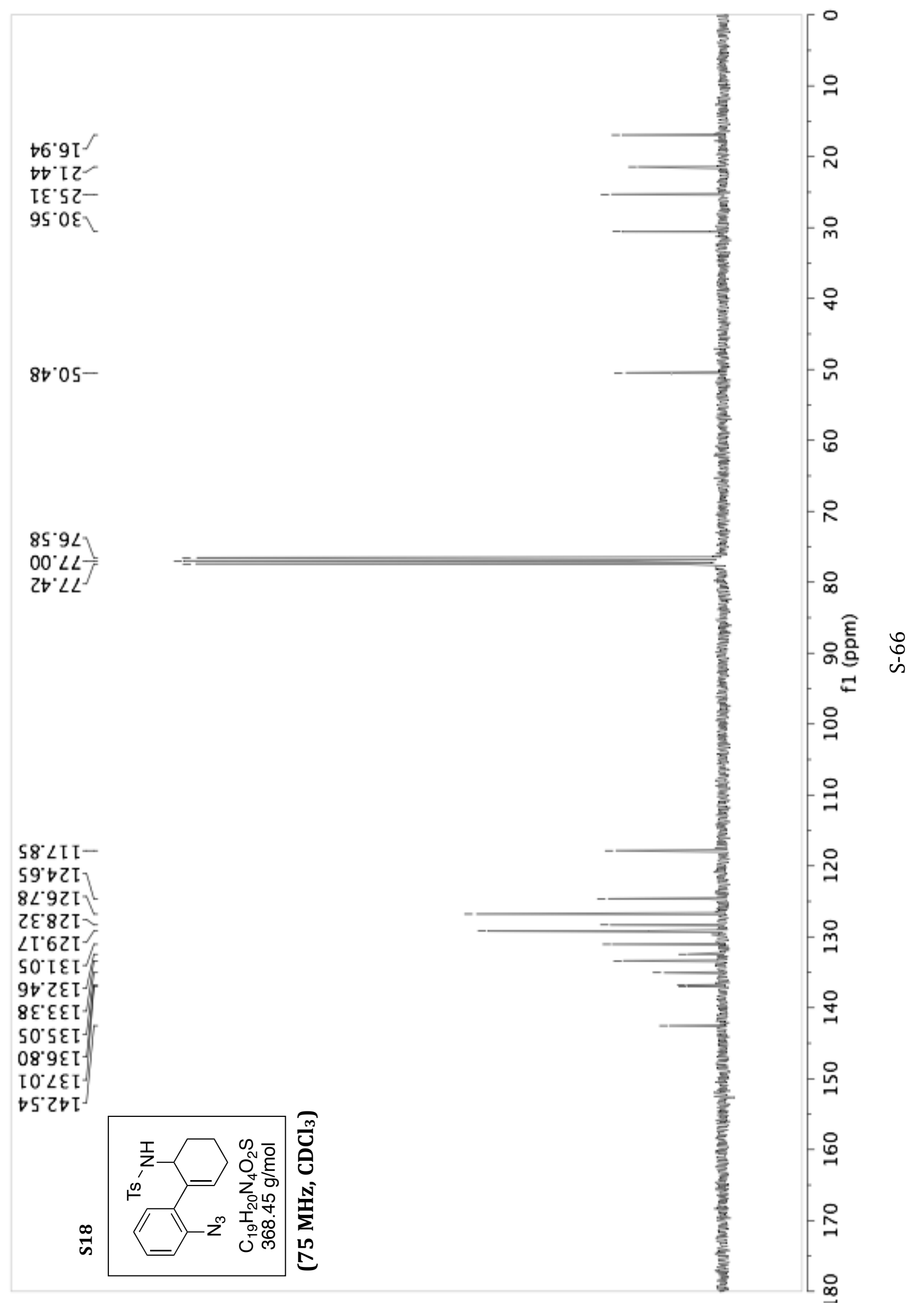




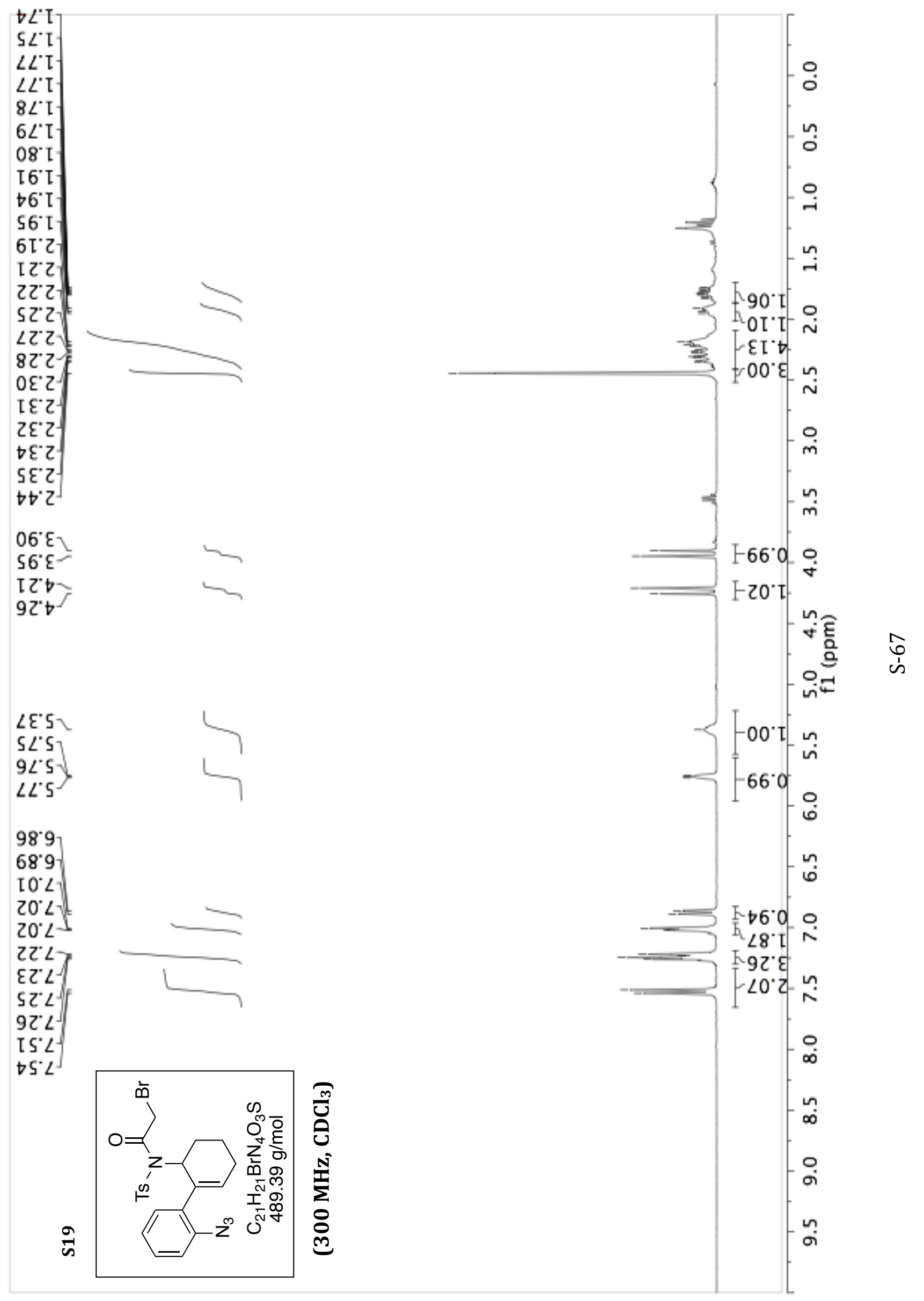




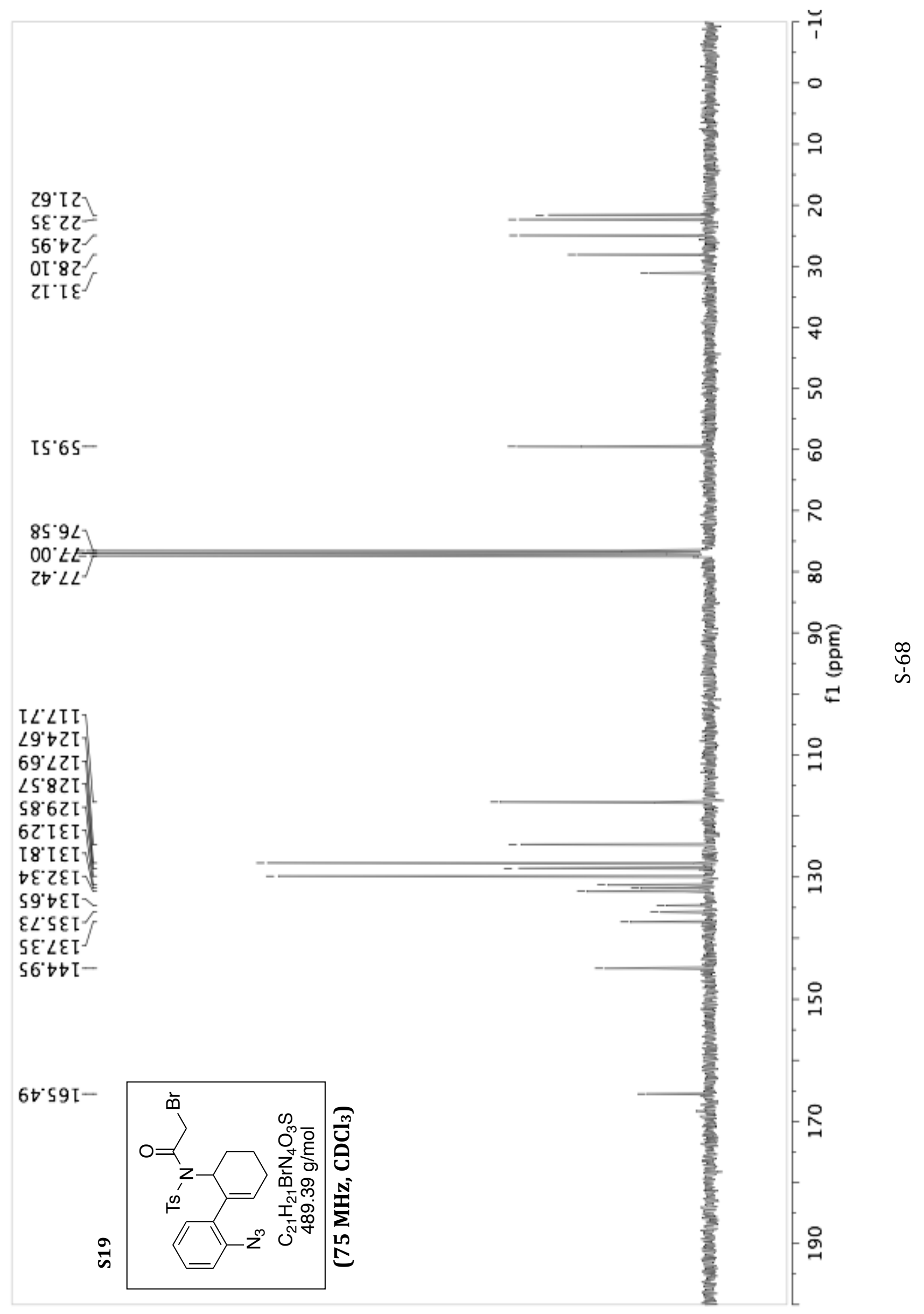




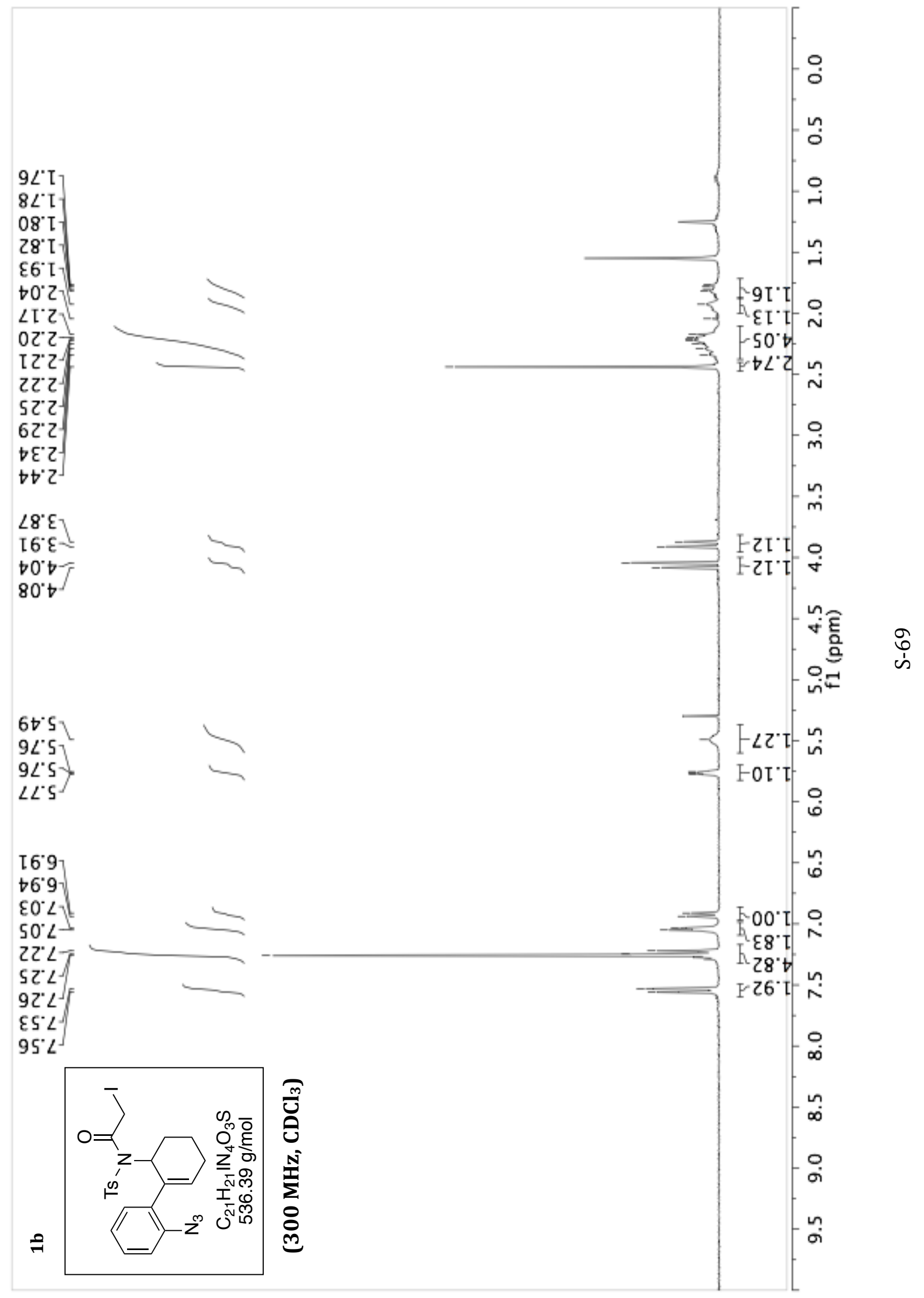




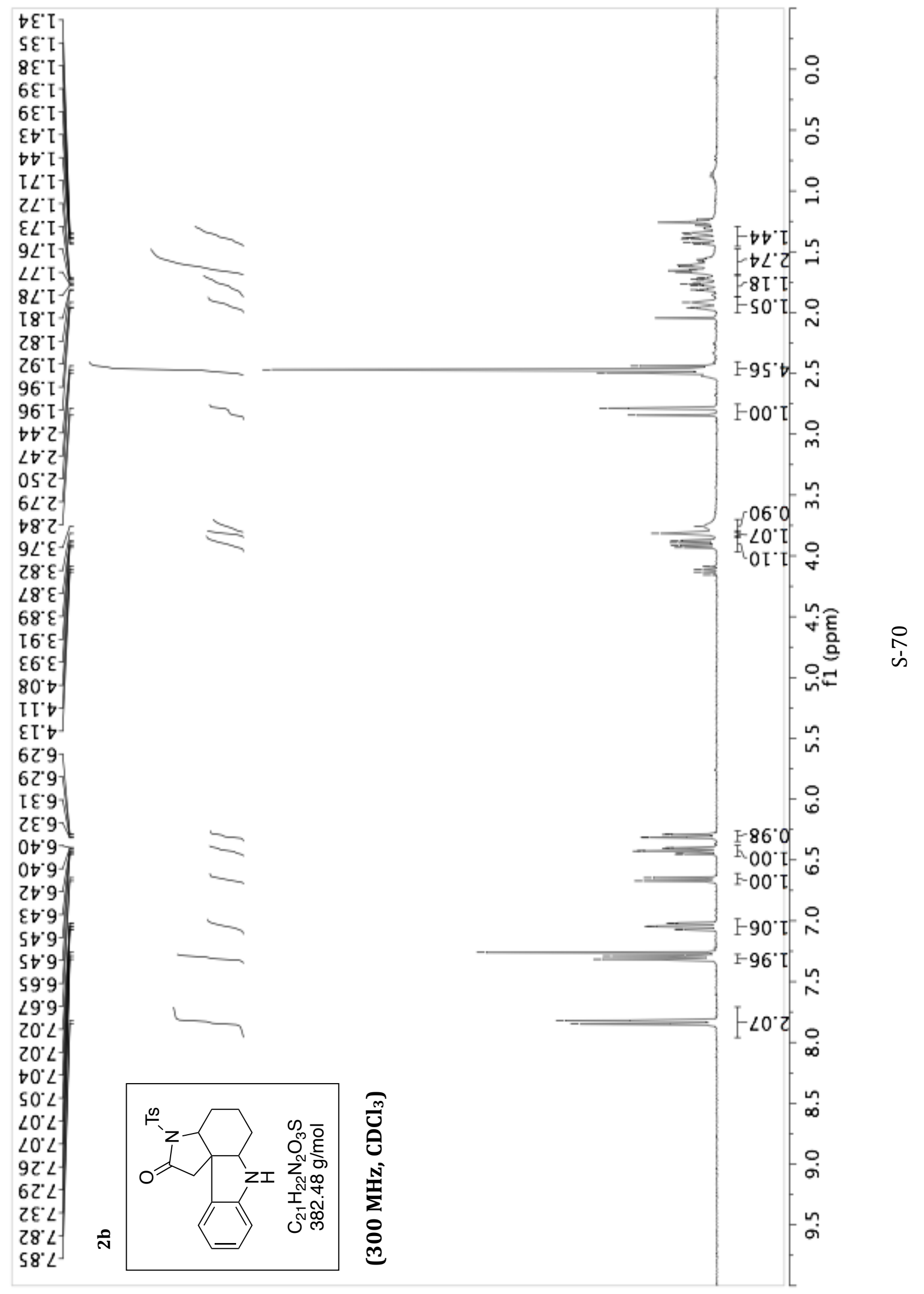




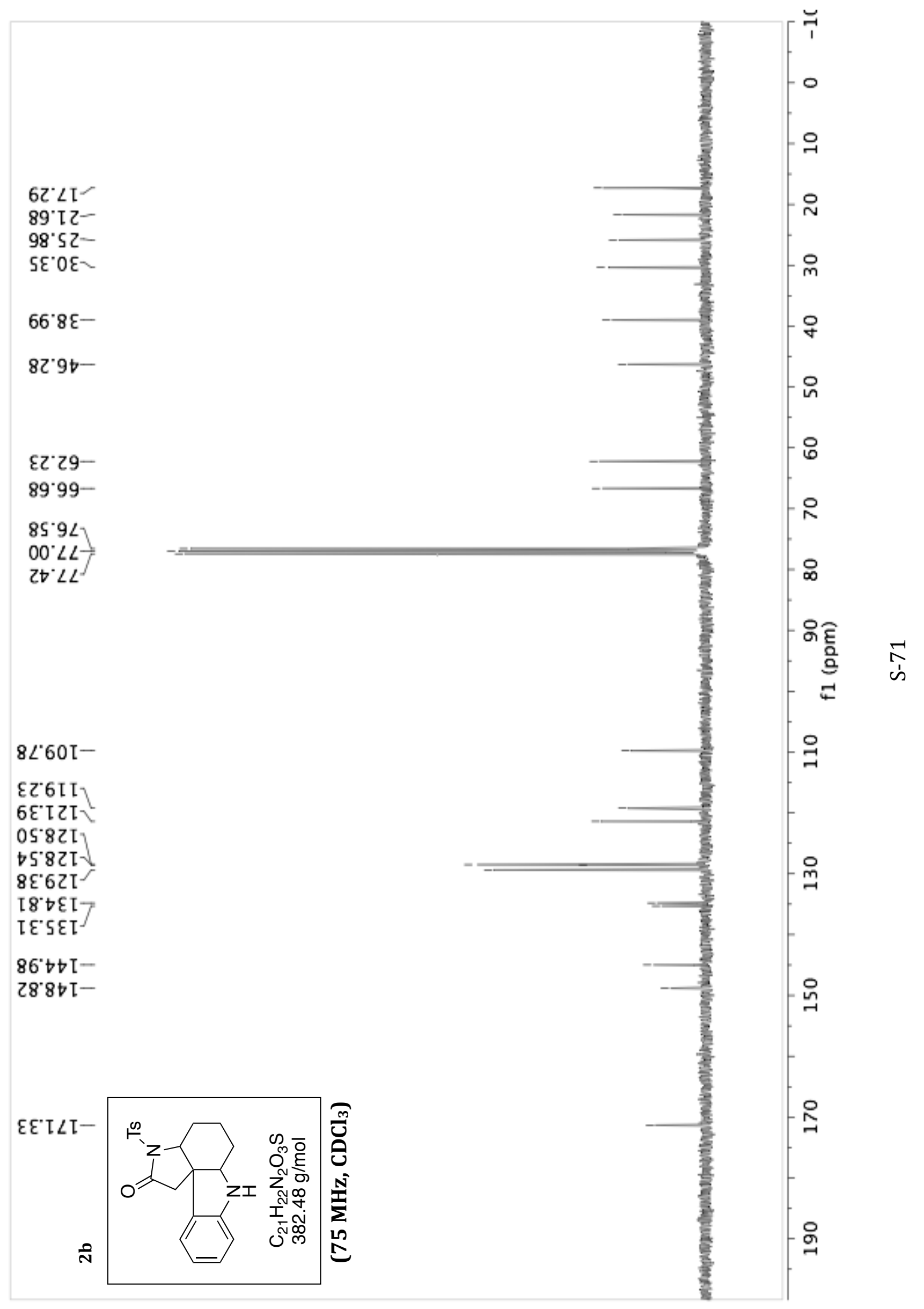




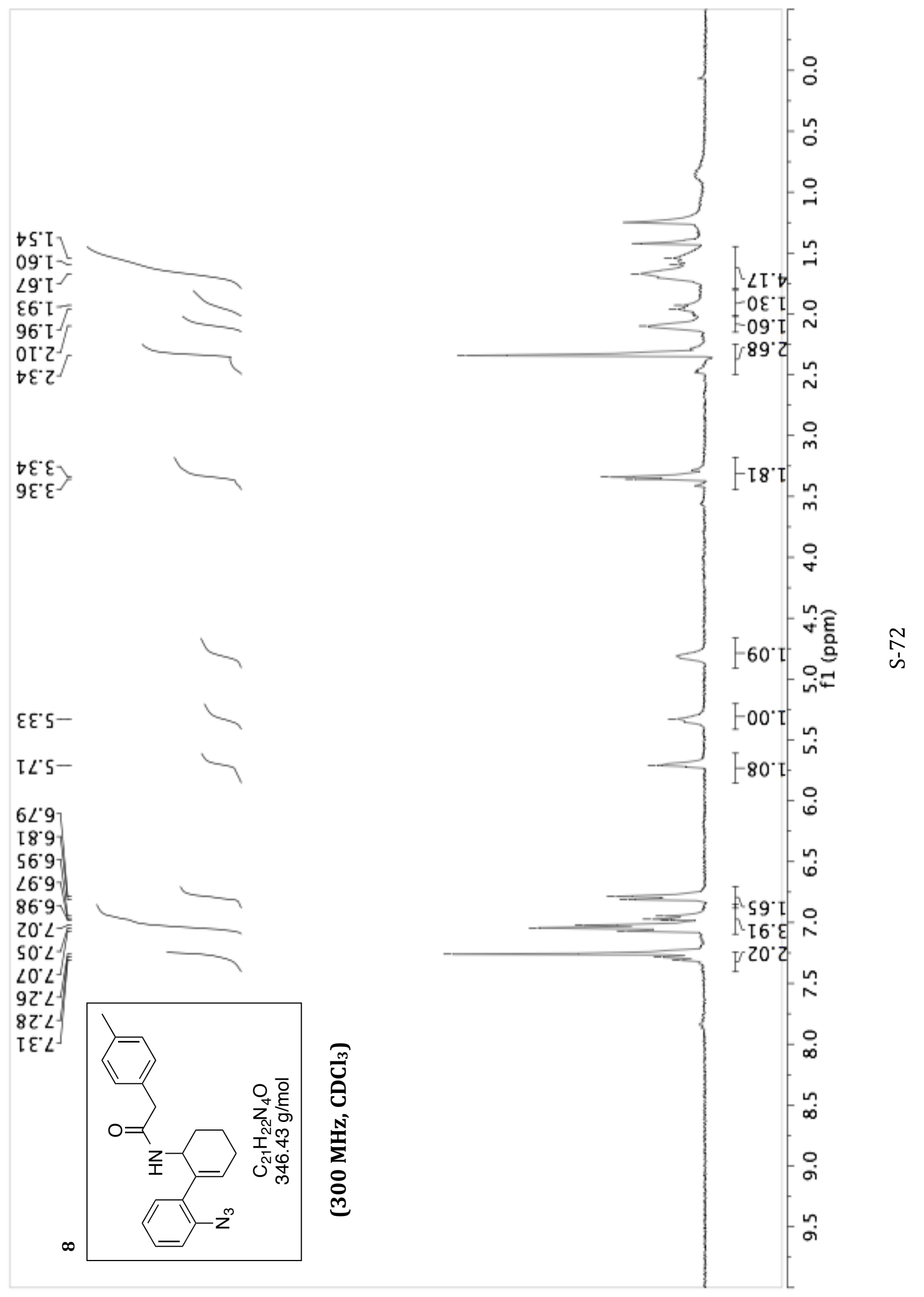




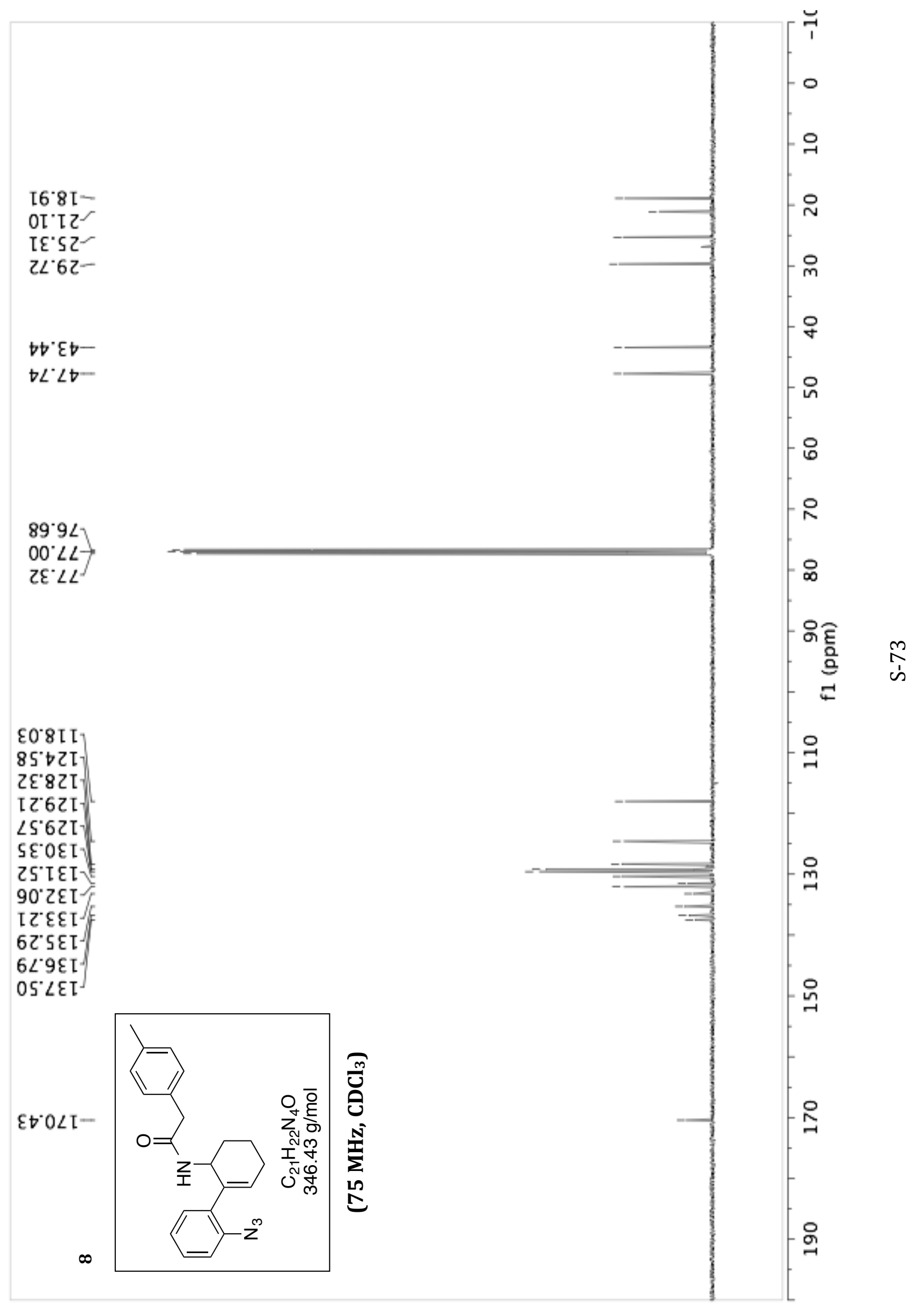


(udd) โ†

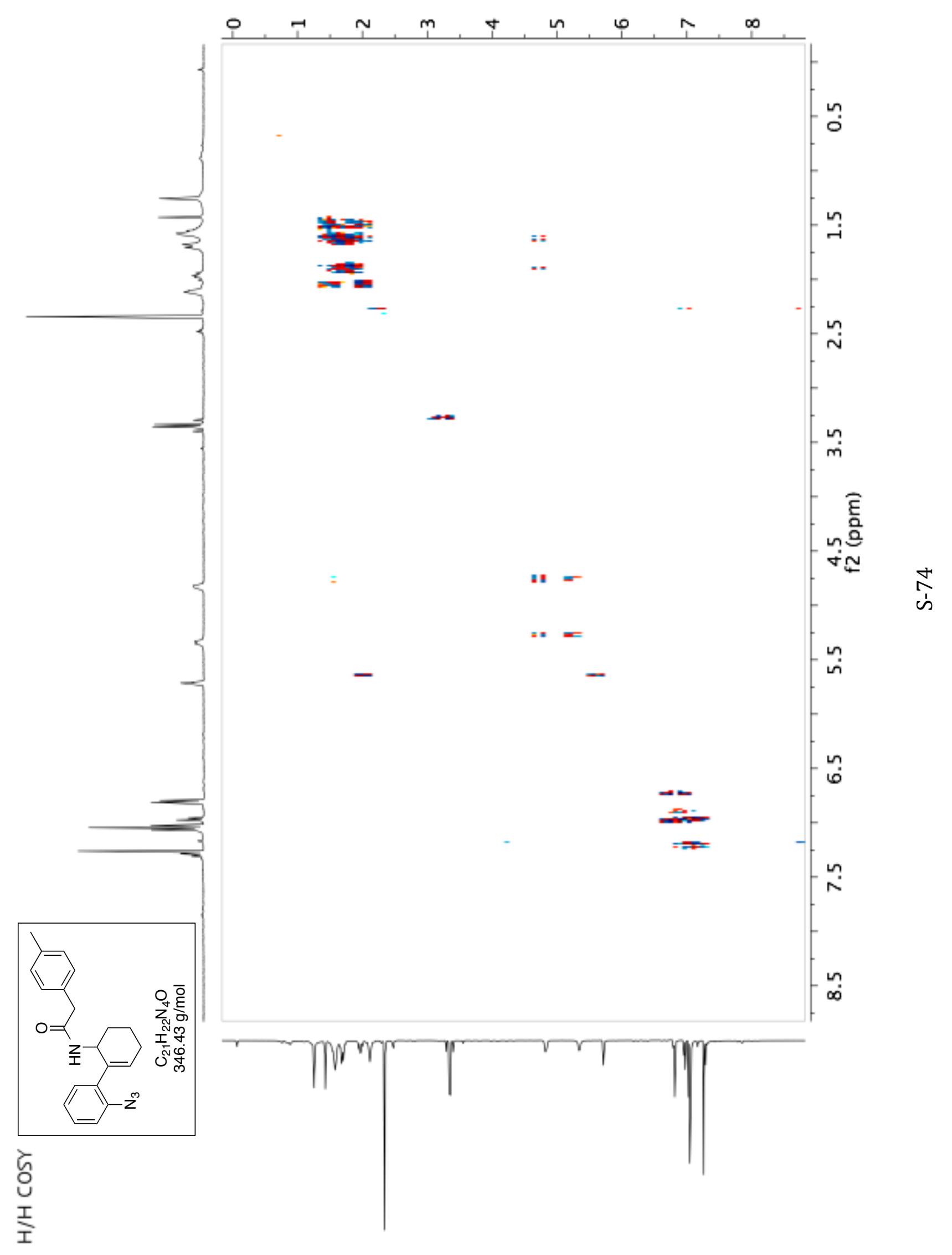


(urdd) if

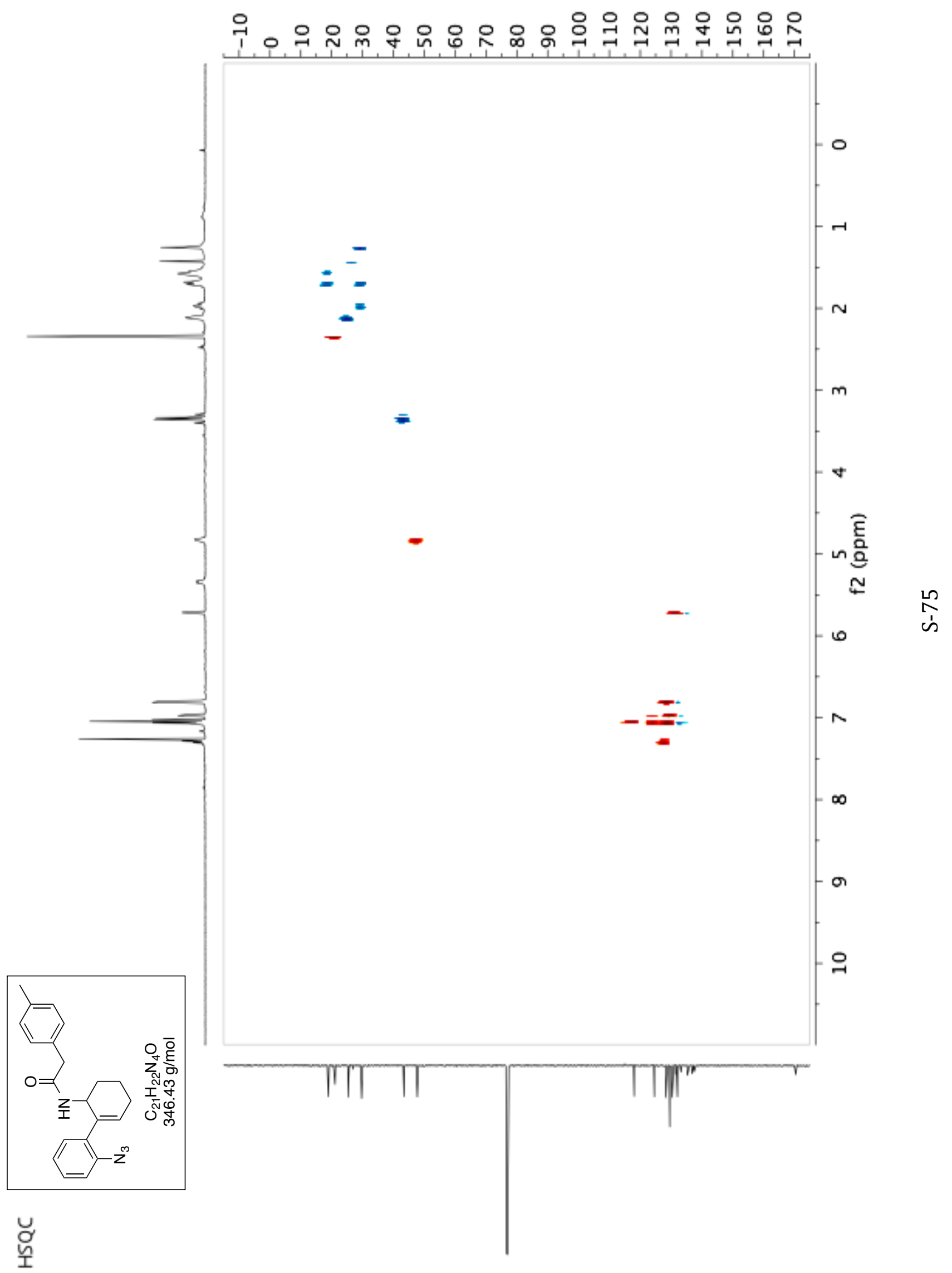


(urdd) Tt

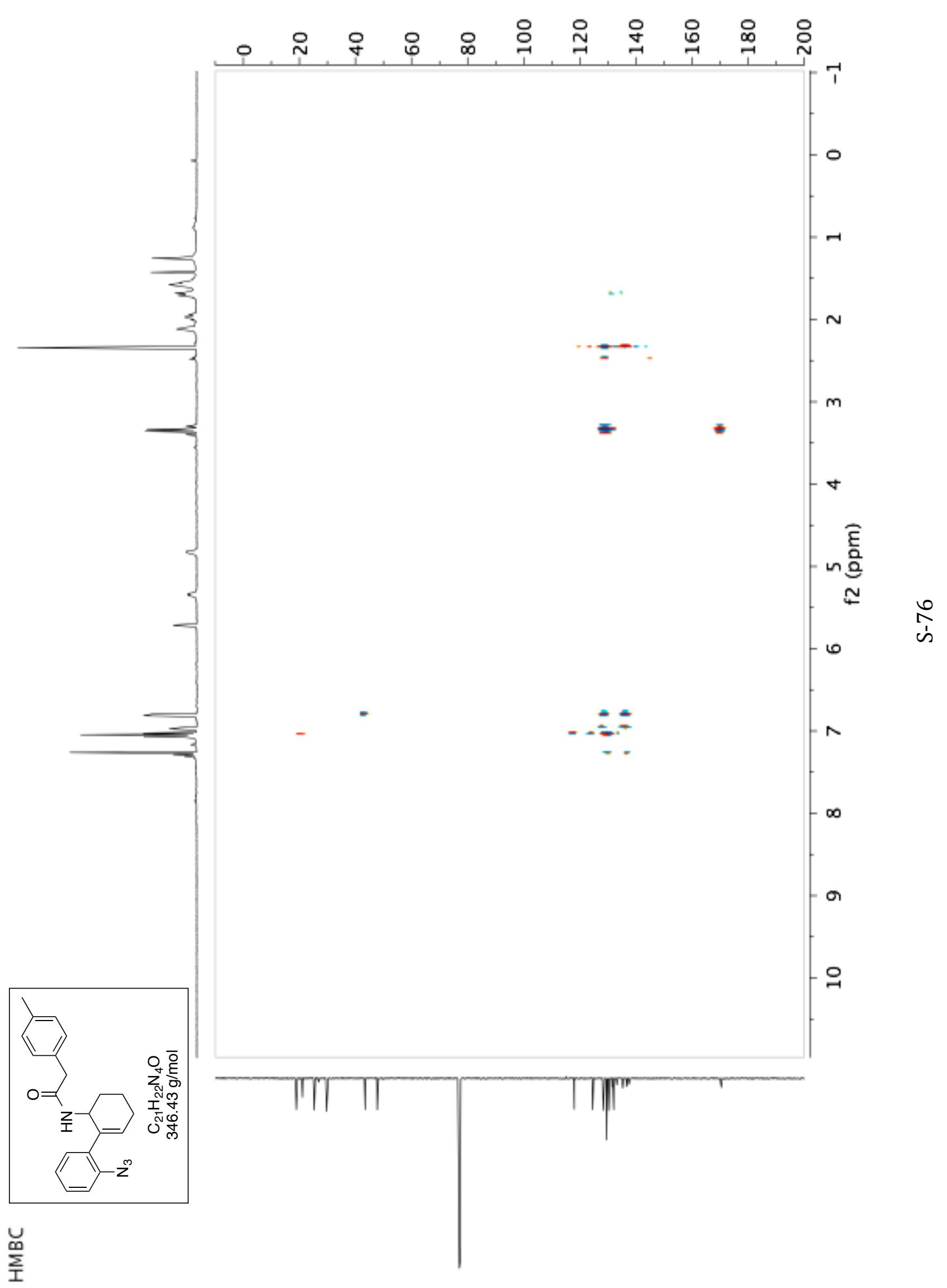

